Fabio Coutinho de Alcântara Gil

\title{
A ONEROSIDADE EXCESSIVA EM CONTRATOS DE ENGINEERING
}

TESE DE DOUTORAMENTO EM DIREITO COMERCIAL

Professora ORIENTAdora:

Professora Associada Dra. RaChel SzTajn

Faculdade de Direito da Universidade de São Paulo

São Paulo 


\title{
Fabio Coutinho de AlCÂNTARa GIL
}

\section{A ONEROSIDADE EXCESSIVA EM CONTRATOS DE ENGINEERING}

\begin{abstract}
Tese Apresentada Como Parte dos REQUisitos PARA OBTENÇÃO dO TÍTULO DE Doutor, Pelo Departamento de Direito Comercial da FACUldade de Direito da UNIVERSIDADE de SÃo PAULO - USP
\end{abstract}

Professora ORIENTADORA:

Professora Associada Dra. RaChel SzTAJN 


\section{AGRADECIMENTOS}

Gostaria de agradecer à Professora Rachel Sztajn, orientadora desta tese, pelo estímulo ao desenvolvimento do trabalho e pelo apoio no enfrentamento de situações adversas;

Ao Professor Eros Grau, sempre amigo e presente;

Aos ex-representantes discentes Roberto e André que me apoiaram e incentivaram;

Ao Professor Francisco Satiro, pela atenção e colaboração;

Aos amigos da Promon, que fizeram com que a engenharia se tornasse "engineering".

Aos meus colegas de escritório, pela paciência e pela grande sorte de poder fazer do trabalho um exercício diário de amizade e alegria. Entre eles, especialmente em relação ao curso, minha mais profunda gratidão ao Caio, que sempre esteve a meu lado, rindo de minhas agruras - e com isso as tornando mais leves - participando de todas as fases do trabalho com inteligência, disponibilidade e desprendimento (valeu, Caiolino!). À Mariana, mais uma do grupo de jovens amigos brilhantes, que me auxiliou em partes importantes da pesquisa. Ao Wanderley, que reviu o trabalho e fez comentários preciosos. E à Maria Helena de sempre: a grande amiga a quem devo muito.

Às minhas Stellas queridas, mãe e irmã, e ao Neu, o companheirão, que está sempre a meu lado, inclusive nas longas horas de revisão de tese, perdendo tempo precioso da companhia de Valéria e Sofia.

À Fernanda e ao Francisco, meus filhos, pelas horas a menos de sua companhia, pela preocupação comigo e pela felicidade de tê-los.

À Cássia, a quem devo estar escrevendo esse agradecimento. 


\section{RESUMO}

O presente trabalho visa analisar em que medida a alteração das circunstâncias negociais que levem à situação de onerosidade excessiva prevista pelo Código Civil produz efeitos sobre a utilidade que as partes derivam dos contratos de engineering, considerados estes como contratos que têm por objeto o desenvolvimento de projetos industriais e de infraestrutura de grande porte. Situa esses contratos em seu contexto histórico e social, descrevendo seus principais elementos de distinção, especialmente a complexidade e risco das operações econômicas que lhes é subjacente e os qualifica como contratos socialmente típicos, sujeitos ao regime dos contratos de empreitada. A tese discute a adequação do tratamento jurisprudencial que vem sendo dado à onerosidade excessiva e descreve os esquemas negociais geralmente usados em tais contratos para fins de alocação de riscos. Finalmente, a tese discute a aplicação de modelos da Análise Econômica do Direito, como a Teoria dos Contratos Incompletos, como subsídio para a valoração de aplicabilidade das normas sobre onerosidade excessiva aos contratos de engineering e análise dos efeitos de sua aplicação sobre esses contratos.

Palavras-chave: contatos de engineering - onerosidade excessiva - complexidade alocação de riscos - Análise Econômica do Direito - Teoria dos Contratos Incompletos 


\begin{abstract}
The aim of this work is to analyze to what extent changed circumstances that are contractually relevant, so as to characterize the legal figure of excessive onerosity [a situation of material burden for complying with a given obligation on one of the contracting parties] pursuant to the Brazilian Civil Code, bring about effects on the payoffs the contracting parties derive from so-called engineering agreements, understood as agreements for the development of large-scale industrial and infrastructure projects. The work traces back the historical and social context of such agreements and describes their main distinguishing features, especially the complexity and risk elements of their underlying economic transactions. The work also describes such agreements as "socially" codified agreements, subject to the discipline of a legally codified figure called "empreitada" [or contractor agreement]. The work also discusses how court precedents deal with the legal figure of excessive onerosity and describes the deal structures normally used in such agreements for the purposes of risk allocation. Finally, the work discusses the application of Law \& Economics models, such as the Theory of Incomplete Contracts, as a tool for evaluating the applicability of rules governing the legal figure of excessive onerosity to engineering agreements and analyzing their respective effects.
\end{abstract}

Key-words: engineering agreements - excessive onerosity- complexity - risk allocation Law \& Economics - Theory of Incomplete Contracts. 


\section{RÉSUMÉ}

Cet exposé cherche à analyser jusqu'à quel niveau le changement des circonstances des affaires menant à une situation d'excessive onérosité prévue au Code Civil produit des effets sur l'utilité que les parts obtiennent des contrats d'engineering, ceux-ci étant considérés comme des contrats dont le but est le développement de projets industriels et d'infrastructure de grande taille. Les contrats y sont mis à leur place dans leur contexte historique et social, en décrivant leur principaux éléments de distinctions, surtout leur complexité et le risque des opérations économiques y imputés et les qualifie comme des contrats socialement typiques soumis au régime de contrats d'entreprise. La thèse discute de la convenance du traitement de jurisprudence donné ces derniers temps à une situation d'excessive onérosité et décrit les schémas d'affaires utilisés d'une façon générale dans ces contrats pour la définition d'attribution de risques. Finalement, la thèse discute l'usage des modèles de l'Analyse Economique du Droit ainsi que la Théorie des Contrats Incomplets, tels que la subvention pour faire valoir la mise en pratique des normes sur une situation d'excessive onérosité dans ces contrats d'engineering et l'analyse de leurs effets lors de leur mise en pratique.

Mots-clé : contrats d'engineering - excessive onérosité - complexité - d'attribution de risques - Analyse Economique du Droit - Théorie des Contrats Incomplets. 


\section{SUMÁRIO}

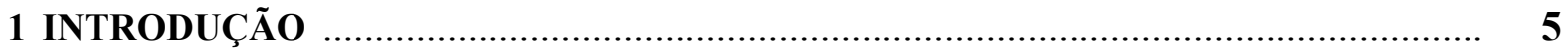

2 DELINEAMENTO DOS CONTRATOS DE ENGINEERING …............................. 7

2.1 Contextualização histórica e social ............................................................................ 8

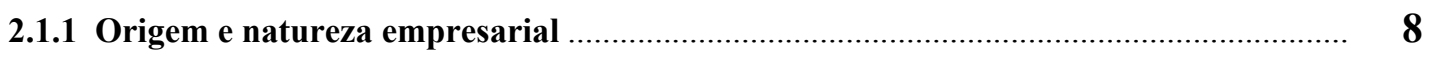

2.1.2 A influência da Globalização ……………………………………………………..... 12

2.2 Utilização de contratos-tipo ou modelos uniformes .................................................. 18

2.3 Definição dos Contratos de Engineering ……….................................................... 25

2.3.1 Da necessária presença de pessoa que exerça a atividade empresarial de engenharia.... 27

2.3.2 A complexidade do conteúdo e execução contratuais ...................................................... 29

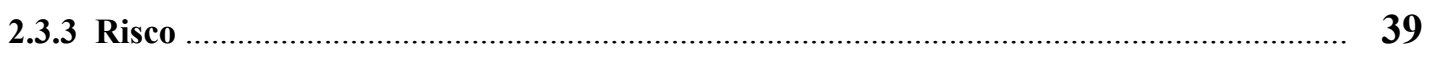

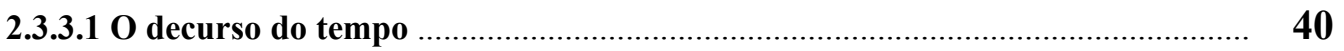

2.3.3.2 Risco, controlabilidade e prevenção ……………………………………............ 43

2.4 Qualificação dos Contratos de Engineering ………............................................... 46

3 APLICAÇÃO DA TEORIA DA ONEROSIDADE EXCESSIVA AOS

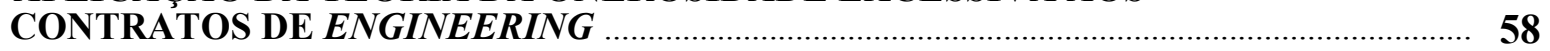

3.1 A flexibilização do vínculo contratual .................................................................... 59

3.1.1 Da santidade dos pactos à efficient breach ……………………................................ 60

3.1.2 Notas sobre a introdução do remédio da onerosidade excessiva no Brasil e a experiência do direito comparado ...................................................................... 69

3.1.3 Intervenção do juiz na relação contratual .................................................................... 76

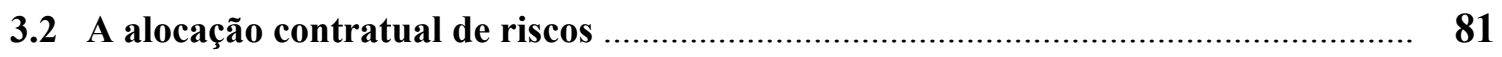

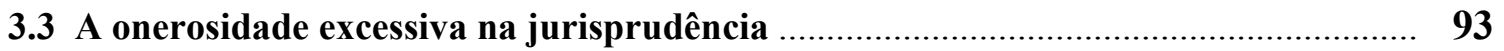

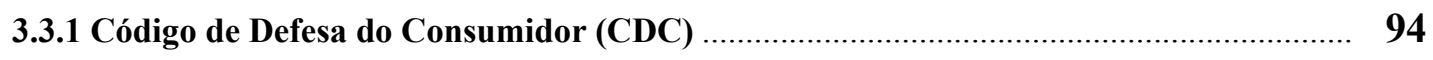

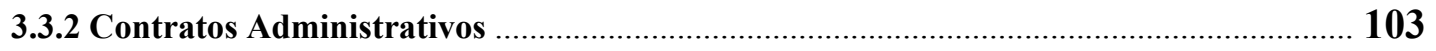

3.3.3 Considerações sobre a jurisprudência ………………………………………………..... 109

4 A PERSPECTIVA DA ANÁLISE ECONÔMICA DO DIREITO ..........................................111

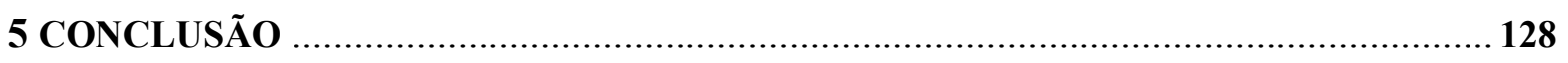

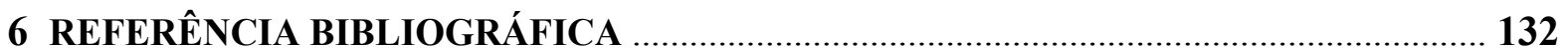




\section{INTRODUÇÃO}

[...] because contracts are the major means by which one firm interrelates with another firm, or one organization interrelates with the consumer. They are, in effect, the neurons of the economic system. Of course, studying the contracts has to be supplemented by a study of the actions of the firms in modifying and interpreting the terms of the contracts.

[Ronald Coase, Why Economics Will Change, Comentários proferidos na Universidade de Missouri, Columbia, Missouri, em 4 de abril de $\left.2002^{1}\right]$

O Novo Código Civil Brasileiro (Lei ${ }^{\circ}$. 10.406, de 10 de janeiro de 2002) introduziu no ordenamento jurídico disposições que tratam da resolução do contrato por onerosidade excessiva. Em termos resumidos, nos contratos de execução continuada ou diferida, essas disposições permitem ao contratante buscar a resolução ou renegociação do contrato, se a prestação de uma das partes se tornar excessivamente onerosa, com extrema vantagem para a outra, em virtude de acontecimentos extraordinários e imprevisíveis. A consideração da possibilidade de resolução do contrato por onerosidade excessiva se contrapõe, do ponto de vista lógico, ao princípio da força obrigatória dos contratos, um dos pilares da teoria geral dos contratos.

A presente tese visa a estudar a aplicação da noção de equilíbrio econômico dos contratos e, conseqüentemente, da noção de onerosidade excessiva, em relação aos contratos de engineering, considerados como contratos em que uma parte (normalmente uma empresa) se obriga frente à outra, a elaborar um projeto de natureza industrial, arquitetônica, urbanística e usualmente a realizá-lo, ou mesmo realizar projeto elaborado por outra empresa, dispondo-se também, se convencionado, a desenvolver

${ }^{1}$ Constante do site do Ronald Coase Institute em: http://coase.org/coaseremarks2002.htm. (acesso em 15.12.2005); 
prestações acessórias de assistência técnica, recebendo, a título de contraprestação, soma em dinheiro, integrada ou substituída por royalties, ou participação nos resultados da atividade empresarial desenvolvida em seguida à realização do projeto ${ }^{2}$. São predominantemente contratos que têm por objeto o desenvolvimento de projetos industriais e de infra-estrutura de grande porte.

Os contratos de engineering são de modelo de contrato de longa duração, técnica e economicamente complexos, em oposição ao modelo de contrato de execução instantânea e de mero intercâmbio, sobre que se assenta a dogmática jurídica tradicional. Procura-se demonstrar que o equilíbrio econômico do contrato de longa duração está sujeito a variáveis diversas, que serão analisadas na presente tese.

Adicionalmente, vale sublinhar que o equilíbrio dos contratos de engineering é considerado sob a perspectiva dos contratos celebrados mediante efetiva negociação entre as partes, geralmente empresas ${ }^{3}$, como já dito, por oposição aos contratos entre partes em posição jurídica de desigualdade.

\footnotetext{
${ }^{2}$ Segundo definição de Cavallo Borgia, R., Il Contratto di Engineering, Pádua Cedam, 1992, p. 135, discutida, em conjunto com outras, no capítulo 3 , abaixo.

${ }^{3}$ Roppo, V., Il Contratto, Milão, Giuffré, 2001, pp. 84-85. O autor assinala que a teoria geral dos contratos vem sofrendo processo fragmentação interna, já que o elemento que vem prevalecendo na determinação da disciplina contratual é de natureza subjetiva, ou seja, a qualificação sócio-profissional dos sujeitos contratantes, de modo que se delineia com crescente precisão a bipartição entre contratos empresariais e contratos "entre entes privados"; e, com as crescentes instâncias de proteção dos consumidores, a primeira categoria se decompõe nas subcategorias de contratos entre empresas e entre empresa e consumidor:
}

Si offusca l'unità del contratto in genere, e la figura conosce inedite frammentazioni interne. L'elemento che soprattutto le determina è di natura soggettiva, ovvero la qualifica socio-professionale dei soggetti contraenti: acquista sempre maggior rilievo la qualifica di operatore economico, sicché si profila con crescente nettezza la bipartizione fra contratti delle imprese e contratti 'fra privati'; e con le crescenti istanze di protezione dei consumatori la prima categoria ulteriormente si scompone nelle sottocategorie dei contratti fra imprese e fra impresa e consumatore. Ma la frammentazione corre anche sul filo di criteri oggettive: cresce la rilevanza della distinzione fra contratti effettivamente negoziato fra le parti. E contratti predisposti e imposti da una parte all'altra, senza trattativa. 
2 DELINEAMENTO DOS CONTRATOS DE ENGINEERING 


\subsection{CONTEXTUALIZAÇÃO HISTÓRICA E SOCIAL}

\subsubsection{Origem e natureza empresarial}

Como diz Marinelli ${ }^{4}$, os contratos de engineering nascem e se desenvolvem a fim de dar uma resposta (inicialmente técnica e econômica e somente em seguida jurídica) a exigências complexas e diversificadas, que se manifestaram nos primeiros decênios seguintes ao segundo pós-guerra e que foram endereçadas, prevalentemente na experiência anglo-saxã, nos anos sessenta.

Os contratos de engineering são produto da modernidade, em que a disciplina da engenharia se amplia para quase todos os setores da vida: da tradicional construção civil à construção de aeronaves e espaçonaves, da mecânica localizada à linha de montagem, da eletricidade à microeletrônica. Enfim, os contratos de engineering, embora não sejam, eles próprios, massificados, são, sob o ponto de vista jurídico, um dos fatores de consolidação da produção em massa, ao permitir que a indústria se capacite para a produção em escala. Se, na cadeia produtiva, o contrato de consumo situa-se em um de seus extremos - o destino final do produto - os contratos de engineering situam-se, geralmente, no extremo oposto, na estruturação da manufatura, na viabilização da transformação da matéria-prima em produto, seja este final ou intermediário ${ }^{5}$.

\footnotetext{
${ }^{4}$ Marinelli, Fabrizio, “Engineering”, in Nuovi Contratti nella Prassi Civile e Commerciale, vol. XIII.

${ }^{5}$ Kay, The Education of the Construction Work Force in the Post-Industrial Era, 2,7 The American Professional Constructor 25 (April 2003); apud, Bruner, P e O’Connor, Jr, P.; Bruner \& O’Connor on Construction Law, West Group, 2006 Cumulative Supplement - vol. 1 p.4, § 1:2:
}

[I]n the literature on the shift from industrial to post-industrial society, one of American's largest industries - construction - is scarcely mentioned, Given that the 'new economy' based on intangibles will rule the old economy based on the manufacture of the tangible, how will a construction industry, by nature focused on the tangible, adapt to this change? Although the construction industry is considered part of the manufacturing sector of the economy, the industry differs in most respects from high-volume mass production of goods, In stark contrast to the controlled manufacturing facility, each 'unit' produced by a construction contractor is 'assembled' at a different geographic location, to a different design conceived by a different designer, by skilled workers from dozens of specialized trades 
Assim, quando se pensa em contrato de engineering, pensa-se na obra de engenharia de grande porte, nas instalações industriais, inclusive as usinas de energia, na infra-estrutura que possibilita a circulação de mercadorias, nas mais diversas áreas, da indústria manufatureira às unidades geradoras de energia, das obras privadas às públicas. Antes de serem contratos da economia da informação, da pós-modernidade, são contratos da economia de massa. Sucedem, em linha de evolução histórica, os contratos da economia agrária, com a extensão da Revolução Industrial da Inglaterra à Europa Continental e América do Norte.

Para Clóvis V. do Couto e Silva ${ }^{6}$, no Brasil, o desenvolvimento do contrato de engineering associa-se à tendência protecionista dos anos 60 e 70, que influiu sobre a história desse tipo contratual por intermédio da edição do Decreto $\mathrm{n}^{\mathrm{o}}$. 64.345 de 10 de abril de 1969. Esse Decreto já se referia expressamente à reserva de mercado para contratação de empresas nacionais de engenharia pela Administração Pública, reconhecendo, portanto, a existência de empresas de engenharia - em contraste com a antiga concepção da engenharia como profissão liberal. Um dos Decretos modificadores do Decreto $\mathrm{n}^{\mathrm{o}}$. 64.345/69, o Decreto $\mathrm{n}^{\mathrm{o}}$. 66.717/70, chegava mesmo a definir o que se entendia por serviços de engenharia, para efeitos da proteção da reserva de mercado para contratação pelo Poder Público ${ }^{7}$. Entre os serviços ali mencionados, constava a "execução, supervisão e controle da instalação e da montagem de unidades industriais".

and sub-contractors, and is made to order for its purchaser, Construction contractors can rarely achieve any economies of scale by building more units, even by building the same design repeatedly, because the changing location of each project involves changing site conditions (geology, foundation soils, ground water, and weather conditions), changing municipal ordinances and regulations, a changing work force, and a mix of subcontractors and other difficulties. There is limited opportunity to apply automation to most construction processes, and limits are placed on productivity improvements due to the complex interplay of sub-contractors and conflicts in the scheduling of their component parts of the work. For these and other reasons, construction has never been directly comparable to other forms of manufacturing,

${ }^{6}$ Couto e Silva, Clóvis V.; Contrato de “Engineering”, Revista dos Tribunais vol. 685, nov/1992, pp. 29-40.

${ }^{7}$ Decreto $n^{\mathrm{o}} .66 .717 / 70$, art. $1^{\mathrm{o}}$ :

Entendem-se como abrangidos pelo artigo $1^{\circ}$ do Decreto número 64.345, de 10 de abril de 1969, os serviços de engenharia em geral, a saber: I - Elaboração de estudos e projetos de engenharia; II - Execução, supervisão e contrôle da implantação de obras de construção civil; III - Execução, supervisão e contrôle 
Embora a associação estabelecida por Couto e Silva seja ilustrativa, é certo que já a Lei $\mathrm{n}^{\circ}$. 5.194, de 24 de dezembro de 1966, ainda vigente, que regula o exercício das profissões de Engenheiro, Arquiteto e Engenheiro-Agrônomo, admitia, em seus artigos $8^{\circ}$ e $9^{\circ}$, a execução de serviços de engenharia, inclusive a execução de obras e serviços técnicos ${ }^{8}$, por pessoas jurídicas. Dessa maneira, antes mesmo da reserva de mercado - que só viria a ser eliminada no início dos anos 90 - já se admitia o exercício empresarial da engenharia no Brasil.

Em realidade, o fenômeno do exercício empresarial da engenharia surgira no início do século XX nos Estados Unidos, quando lá já se encontravam as primeiras companhias de engenharia. Como nota William B. Stitt ${ }^{9}$, em 1907 surgia a primeira lei de regulamentação da atividade de engenharia no estado de Wyoming e, em 1921, as primeiras leis regulamentando a atividade empresarial de engenharia nos estados de Minnesota, Nova York, Carolina do Norte e Oregon ${ }^{10}$.

A razão da integração da engenharia à atividade empresarial decorria, segundo Stitt, das inegáveis vantagens do exercício da disciplina sob a forma empresarial. As crescentes magnitude e complexidade dos projetos de engenharia demandavam cada vez maior integração entre os engenheiros das diversas especialidades envolvidas em cada projeto, geralmente de execução prolongada. O desenvolvimento da ciência e tecnologia, por outro lado, demandava conhecimentos especializados que deveriam ser integrados em um todo. Por outro lado, para a manutenção de pessoal em grande número, em várias especialidades, até o final de cada projeto, requeria-se a mobilização de capitais vultosos, tornando impossível a acumulação do capital necessário ao desenvolvimento desses grandes projetos por indivíduos, pessoas naturais.

Embora, nos Estados Unidos, como em outros países, inclusive Itália, tenha havido oposição ao exercício empresarial da engenharia, a tendência se difundiu

da construção de estradas de rodagem e de ferrovias; IV - Execução, supervisão e controle da instalação e da montagem da unidades industriais.

${ }^{8}$ Lei no. 5.194/66, art. $9^{\circ}$ c/c art. $8^{\circ}$, alínea “g”.

${ }^{9}$ Stit, W. B; Corporate Practice of Engineering, The Business Lawyer, vol. 14, julho/1959, pp. 969-988.

${ }^{10}$ Stitt, W. B; op. cit. p. 972. 
mundialmente, mesmo porque, na prática, a atividade de engenharia não prescindia do emprego e organização de capital e trabalho, que caracteriza a atividade empresarial. ${ }^{11}$

Os contratos de engineering são, pois, resultado da maturidade da era industrial, da crescente complexidade tecnológica que passou a demandar a concentração de capital e trabalho para o desenvolvimento de uma economia que passou a ser de massas, e não mais agrária, como outrora. Por essa razão, os contratos de engineering são notadamente contratos de empresa - não só porque derivam da estruturação das empresas de engenharia, mas também porque geralmente são celebrados entre empresas entre si (ainda que, por esforço teórico, pense-se em empresa individual), ou entre empresas e Poder Público, este, ente igualmente personificado.

Mais que isso, adotando a linha de raciocínio de Vincenzo Roppo, como o contrato tornou-se um mecanismo essencialmente funcional à empresa ${ }^{12}$, parece

11 Stitt, W. B.; op. cit, pp. 971-972, oferece interessante descrição da evolução organizacional da engenharia:

Originally the function of the engineer (other than the surveying activity of civil engineers) was chiefly limited to designing, his designs being translated into a finished project by a contractor who performed the construction work under the supervision of the engineer, acting as the representative of his client. As projects grew more complex, it became increasingly difficult to correlate all the facets of a project and to harmonize the separate interests involved. It therefore became the custom to have an engineer not only design but also carry out the construction work, with the engineer employing the necessary construction personnel as agent for his client. This mode of operation was requested more and more by clients and in turn led engineering organizations to increase their staffs by employing the engineers and other engineering personnel formerly employed by contractors. Eventually not only did many engineering organizations assume the functions of contractors, in addition to functions primarily performed only by engineers, but many contracting organizations developed engineering staffs and eventually departments which in some instances acquired such high reputations that the principal corporate activity became engineering rather than construction work. No matter in which direction the combination or expansion of activities took place the end result almost always was a corporate form of organization. Furthermore the engineer's earlier attention to the protection of his client against the contractor shifted to the protection of the client in the latter's relations with manufacturers or suppliers of materials. The development of such combined operations, the assumption of new functions by engineers and the transition of activities into new and expanding fields all were contributing factors to the formation of corporations which engaged in the practice of engineering whether originally or chiefly engineers or contractors. Other reasons for the expanded use of the corporate form included the continuity of existence possible through incorporation and other advantages which corporations enjoy under our corporate and tax laws, including the ability of a corporation to accumulate necessary working capital in large amounts far greater than is possible for an individual or partnership.

${ }^{12}$ Roppo, Vincenzo, Il Contratto, Milão, Giuffré, 2001, pp. 58: “da meccanismo essenzialmente funzionale alla proprietà, il contratto diventa meccanismo essenzialmente funzionale all'impresa." 
correto dizer que, no momento em que a economia passou a demandar grandes obras e instalações industriais para a consecução da produção em massa, tornou-se inviável a condução de empreendimentos de vulto em regime profissional liberal, essencialmente individual, passando a afigurar-se a organização empresarial como a mais eficiente. Organizada a atividade de engenharia sob a forma empresarial, daí derivaram os contratos de engineering, em sua forma atual.

Da caracterização empresarial dos contratos de engineering decorrem conseqüências relacionadas à disciplina jurídica aplicável ao contrato, especialmente no que toca à sua tipificação, como se verá adiante.

\subsubsection{A influência da Globalização}

A evolução histórica dos contratos de engineering chega a nossos dias tanto como resultado da transformação organizacional por que passaram - e têm passado - engenharia e arquitetura, como modalidade contratual também sujeita às vicissitudes da Teoria Geral dos Contratos. Com efeito, pode-se dizer que os contratos de engineering surgem na Era Industrial e se situam na Era Pós-Industrial cercados das polêmicas relacionadas ao contrato como categoria jurídica, sem deixar de revelar peculiaridades próprias.

Desde que Grant Gilmore anunciou a morte do contrato ${ }^{13}$, não sem, ao final de seu livro", considerar a hipótese de "ressurreição" dessa categoria jurídica, muito se discutiu sobre suas crises, até que o advento do fenômeno da Globalização parece ter indicado a tendência à "reprivatização" do direito, conforme José Eduardo Faria ${ }^{15}$ dada a contração da tutela estatal com conseqüente expansão das relações contratuais. Colocando a soberania estatal em jogo, a Globalização faz substituir a tutela estatal das

\footnotetext{
13 "The Death of Contract", cuja primeira publicação data de junho de 1974. Vide edição desse livro por Ronald K. L Collins (Ohio State University Press - Columbus, 2nd. ed. , 1995, p. viii), dizendo que "Now, some twenty years after its original publication, THE DEATH OF CONTRACT may itself appear dead."

${ }^{14}$ Op. cit., p. 112.

${ }^{15}$ Faria, J. E. e Kuntz, R. ; Qual o Futuro dos Direitos?, Max Limonad, 2002, p. 100.
} 
relações entre particulares pela negociação direta ${ }^{16}$, o que favorece a liberdade de contratação e amplitude da negociação.

De fato, o Estado se vê na condição de não ter mais meios de ser onipresente, interferindo maciçamente na esfera privada, como no passado industrial. Nos países em desenvolvimento, a contração orçamentária causada pelo esgotamento dos recursos públicos - em grande parte canalizados para o pagamento das dívidas públicas interna e externa - faz com que o Judiciário não tenha mais condições de atender à demanda pela tutela dos novos direitos que, paradoxalmente, o Estado intervencionista da Era Industrial reconheceu aos cidadãos e mesmo às empresas. No lado dos países desenvolvidos, o contrato passa a ser a grande opção para a penetração em mercados emergentes e inter-relacionamento entre mercados maduros. As grandes empresas multinacionais passam a se apoiar em contratos também como forma de se eximir das tutelas estatais locais (que, nos casos dos países em desenvolvimento, vêem-se às voltas com o crônico emperramento do Judiciário), empregando cláusulas de eleição de foro e lei aplicável ao contrato, assim como cláusulas de arbitragem, que deslocam a resolução de eventuais conflitos para jurisdições mais “confiáveis”, ou teoricamente estáveis.

No caso específico de contratos de engineering, é nítido que os mercados maduros passaram a se voltar para as obras necessárias à infra-estrutura ainda indigente dos países em desenvolvimento. As grandes empresas de engenharia norteamericanas e européias voltam seus olhos para as enormes deficiências estruturais dos países emergentes e, com a Globalização, passam a ficar livres de entraves como reservas de mercados e restrições à importação. Sabe-se que, hoje, uma obra de engenharia de grande porte não prescinde de sistemas de compra (international procurement) sofisticados e globalizados.

Essas mesmas empresas transnacionais trazem consigo a experiência dos contratos-tipo elaborados por associações profissionais e de comércio ${ }^{17}$, que Sweet, um

\footnotetext{
${ }^{16}$ Arnaud, A.; Critique de la raison juridique - 2. Gouvernants sans frontières - Entre mondialisation e postmondialisation,Paris, L.G.D.J., 2003, p. 71:
}

Sur le terrain juridique, c'est toute une transformation de la pratique que s'opère. Ne plus pouvoir se référer toujours à l'autorité de l'État, c'est être amené à inventer; le conseil l'emporte désormais sur la chicane; la négociation, sur le conflit; la conciliation sur la dispute. 
dos mais renomados autores norte-americanos do "Direito da Construção" chamou de "contratos de indústria" 18 . Estes são "redigidos e publicados por, em regra, comitês conjuntos de varias associações profissionais e de comércio" ${ }^{19}$. Macneil e Gudel, citando Quintin Johnstone e Dan Hopson, Jr., relatam que, nos EUA, o American Institute of Architects (A.I.A.) vem atuando desde o início da década de oitenta do Século XIX no desenvolvimento de contratos-tipo, ou modelos uniformes de contratação, na área de construção $^{20}$, que têm sido de grande utilidade no planejamento legal e operacional de vários negócios.

Quer sob a ótica expansionista do mundo desenvolvido e suas empresas transnacionais, quer sob a ótica do mundo em desenvolvimento e sua permanente escassez de meios econômicos, a ordem globalizada passa a ser a da busca da autoregulação, tendo o mercado como base do regime de acumulação capitalista ${ }^{21}$. Nesse

${ }^{17}$ Para uma relação de condições contratuais gerais elaboradas internacionalmente, vide Boggiano, A; International Standard Contracts - The Price of Fainess, Graham \& Troutman/Martinus Nijhoff, Dordrecht, The Neherlands, 1991, pp. 2-5.

${ }^{18}$ Sweet, J.; Confessions of a Law Teacher, International Construction Law Review, vol. 18, 2001, p. 541.

19 Seweet, J., op.cit.:

[Industry contracts] were drafted and published by, as a rule, joint committees, of various professional and trade associations. For example, the associations that represented purchasing agents might meet with an association that represented sellers in a particular industry. In a classic industry contract, one made by associations representing buyers and one representing sellers, each association acted as a surrogate for its members who will make contracts in the future. An individual buyer or seller was not compelled to use this industry contract but for many reasons, most dealing with reducing transaction costs, most did use them in full, with minor revisions or as the basis for negotiations. It can be seen that such contracts are not adhesion contracts as defined earlier in this paper.

${ }^{20}$ Macneil, I e Gudel, P., Contracts - Exchange Transactions and Relations, Foundation Press, New York, 2001, p. 781.

${ }^{21}$ Nesse sentido, Boaventura de Sousa Santos identifica quatro grandes tipos de capitalismo - o capitalismo mercantil, em que o mercado é a instituição central; o capitalismo mesocorporativo, como o japonês, liderado pela grande empresa; o capitalismo social-democrático, assentado na "concertação social entre os parceiros sociais, as organizações representativas dos patrões e dos trabalhadores e o Estado"; e, finalmente, o capitalismo estatal, que se "assenta na centralidade da intervenção estatal como princípio de coordenação em face da fraqueza da ideologia do mercado e das organizações dos parceiros sociais" - para concluir que: "Em geral [...] pode dizer-se que a evolução consiste na globalização do capitalismo mercantil e na conseqüente localização dos capitalismos mesocorporativos, social democrático e estatal. Localização implica desestruturação e adaptação. ” Ou seja, a Globalização, como fenômeno sócio-econômico e político, implica prevalência e onipotência do mercado em escala transnacional, sem que deixem de existir as instituições localizadas. Santos, B. S., Os Processos da Globalização, in "Globalização - Fatalidade ou Utopia?", Santos, B. S., [org.], Edições Afrontamento, Portugal, 2a ed., 2002, pp. 82 e 83. Assim, os Estados-Nação passam a conviver em interconexão com instituição financeiras internacionais e corporações 
contexto, os contratos-tipo passam a servir como técnica de planejamento e gestão, mas também como espécies de normas suplementares ao ordenamento jurídico, a ponto de organismo internacional como a UNCITRAL (United Nations Commission on International Trade Law) ter patrocinado a elaboração do Legal Guide on Drawing up International Contracts for the Construction of Industrial Works ${ }^{22}$ a partir da recomendação de seu Grupo de Trabalho sobre a Nova Ordem Internacional Econômica. Segundo esse Grupo, "o estudo das disposições contratuais comumente ocorrentes em contratos de desenvolvimento industrial internacional seria de especial importância para os países em desenvolvimento, em vista da função da industrialização no processo de desenvolvimento econômico". ${ }^{23}$

A fragmentação jurídica global contemporânea — que, segundo Fischer-Lescano e Teubner ${ }^{24}$, não é somente mais uma das exteriorizações da Globalização, mas um fenômeno legal, político, econômico e cultural mais $\operatorname{amplo}^{25}$ resulta da fragmentação multidimensional da própria sociedade global, não podendo ser combatida, mas, no máximo, compatibilizada. Nesse sentido é que José Eduardo Faria, quando identifica as tendências à reprivatização do direito, também identifica a tendência de uma transformação paradigmática no conteúdo programático do Direito Internacional Público. Este deixa de ser produzido pelos Estados-Nação por intermédio de acordos, convenções e tratados, sendo suas normas cada vez mais interpretadas pela Lex Mercatoria

empresariais transnacionais, exigindo do primeiro, como diz José Eduardo Faria, “diferentes papéis de intermediação que só podem ser efetivamente exercidos com a colaboração deles - e, o que é ainda mais importante, com seu poder de veto" Faria, José Eduardo; O Direito na Economia Globalizada, Malheiros Editores, $1^{\text {a }}$ ed., 2004 pp. 148 e 149

${ }^{22}$ UNCITRAL - Legal Guide on Drawing up International Contracts for the Construction of Industrial Works, Nações Unidas, New York, 1988 - $\quad$ também disponível em: http://www.uncitral.org/uncitral/en/uncitral texts/procurement infrastructure/1988Guide.html (consultado em 30.11.2006).

${ }^{23}$ Legal Guide, op. cit., p. 1.

${ }^{24}$ Fischer-Lescano, Andreas e Teubner, Gunther; "Regime-Collisions: The Vain Search for Legal unity in the Fragmentation of Global Law”, Michigan Journal of International Law 25 (2004), 999-1045.

${ }^{25}$ Op. cit,. p. 1004:

Global legal pluralism, however, is not simply a result of political pluralism, but is instead the expression of deep contradictions between colliding sectors of global society. At core, the fragmentation of global law is not simply abort legal norm collisions or policy-conflicts, but rather has its origin in contradictions between society-wide institutionalized rationalities, which law cannot solve, but which demand a new legal approach to colliding norms. 
e pelo "Direito da Produção" "26. Mais uma vez em relação ao contrato de engineering, observa-se que a exteriorização desse Direito da Produção se faz em grande parte pela adoção de contratos-tipo "self-contained", na expressão de Lapertosa ${ }^{27}$, em que se busca conter todo o programa no próprio instrumento contratual, a fim de que se limite ao máximo a possibilidade de integração externa.

Ora, diante do aparente paradoxo pelo qual, do ponto de vista econômico, o mercado passa a ser a força una e dominante em escala global, enquanto que, do ponto de vista sociológico, há uma enorme fragmentação social, política e cultural ao redor do Globo, dois aspectos parecem emergir: a) do ponto de vista metodológico, ganha força a análise econômica de quase todos os aspectos da vida social ${ }^{28}$; e b) do ponto de vista jurídico, o contrato assume o papel, embora não exclusivo, de catalisador ou compatibilizador dos vários centros de poder (agora não mais sob a força hegemônica do Estado-Nação, mas dispersos entre empresas transnacionais, organizações locais e internacionais, ambivalências jurisdicionais e especializações técnicas).

Ou seja, assim como o mercado tem como base de sustentação o reconhecimento jurídico e social da propriedade e da liberdade de contratação, a metodologia da análise econômica pode oferecer, com seu instrumental analítico - em muitos aspectos matemático ou quantitativo - referencial analítico para o enfrentamento das contradições apontadas por Fischer-Lescano e Teubner, acima. Entre essas

\footnotetext{
${ }^{26}$ Faria, J. E. e Kuntz, R.; op. cit., p. 110 e 111.

${ }^{27}$ Lapertosa, F. L'Engineering, Milão, Giuffrè, 1993, p.: 120:
}

Il che esteriorizza un connotato fondamentale dell' engineering: quello di essere un contratto self-contained, congegnato ciò̀ in modo tale da rimettere completamente la sua disciplina all' autonomia dei contraenti, limitando aI massimo le possibilità di integrazioni esterne, ivi comprese quelle collegate a eventuali incertezze terminologiche.

${ }^{28}$ É interessante a observação de Bingyuan Hsiung sobre o expansionismo da análise econômica da vida social (The Commonality Between Economics and Law, European Journal of Law and Economics, vol. 18 (2004), p. 33:

Since the 1960 and without any coordination, economists, carrying their analytical tools with them, started to move into various other social sciences almost simultaneously. [...] Nevertheless, with the efforts of Becker, Buchanan, Coase, Posner and Tullock, among others, economists have not only successfully occupied a foothold in areas like law, political science and sociology, but seem to have gained ground with each passing day. 
contradições, evidenciam-se os conflitos jurisdicionais emergentes, as dúvidas de competência e a inefetividade dos órgãos de solução do antigo Estado-Nação (Judiciário).

Assim, não se pode deixar de reconhecer que os contratos são o veículo e a língua do mercado globalizado ${ }^{29}$. Nesses mercados, em que a tecnologia não progrediu apenas em setores mais evidentes, como na área da informática, mas progrediu com mesma força nos setores intangíveis dos métodos, processos, finanças e estatística, não se pactuam contratos entre iguais, de valores relevantes (a que o Código Civil se aplica com todo seu vigor), sem que criteriosas análises tenham sido antes feitas. Modelos de análise probabilística, antes de aplicação impossível, são agora executados em microcomputadores caseiros. A própria história se encarregou de nutrir as bases de dados das empresas com informações sobre projetos que falham ou não, estatísticas sobre o tempo e as vicissitudes da natureza contra que antereriormente se debatiam os homens.

Pelas razões acima mencionadas, mas também pela evidente redução de custos de transação, os contratos de engineering, internacionalmente, constituem, dentre as modalidades contratuais, uma das que mais emprega cláusulas uniformes e contratostipo, como os já citados. Necessário, assim, desenvolver esta importante característica da disciplina convencional dos contratos de engineering.

${ }^{29}$ Vide Ferrarese, M., Mercati e globalizzazione. Gli incerti cammini del diritto in Le istituzioni della globalizzazione, Bologna, Mulino, 2000, p. 70:

[...] oggi, il diritto globalizzato si avvicina di più a svolgere il ruolo di una lingua parlata in ambito internazionale; una sorta di passepartout linguistico, che permette di comunicare a persone di diverse nazionalità, ma che ognuno parla a modo proprio, con le propria inflessioni e costruzioni lessicali. 


\title{
2.2 UTILIZAÇÃO DE CONTRATOS-TIPO OU MODELOS UNIFORMES
}

Como já mencionado, as partes nos contratos de engineering lançam mão de vários contratos-tipo, formulários, ou modelos uniformes, tanto no âmbito internacional, como também, especialmente nos países desenvolvidos, nacionalmente.

Para Darcy Bessone, contratos-tipo não se confundem com contratos

de adesão ${ }^{30}$ :

\begin{abstract}
A freqüência das relações idênticas, entre determinadas entidades ou categorias de pessoas, sugere a adoção de normas uniformes, evitando-se repetidas formulações de textos virtualmente iguais. A predeterminação do conteúdo de contratos futuros simplifica a sua conclusão, que se realiza sem discussões pré-contratuais e através de rápida e fácil manifestação da vontade. (...) A principal diferença entre o contrato-tipo e o contrato de adesão é fornecida pela bilateralidade ou unilateralidade de sua criação. $\mathrm{O}$ primeiro é formulado por acordo das partes, como conteúdo prévio de eventuais contratos futuros, ao passo que o segundo é elaborado por uma só das partes, cabendo à outra tão-somente aderir ao contexto unilateralmente preparado.
\end{abstract}

No entanto, como observam Netto, Christudason e Kor ${ }^{31}$, embora do ponto de vista classificatório o contrato-tipo dogmaticamente se distinga do contrato celebrado por adesão, é certo que os primeiros podem ser subclassificados como contratos negociados e contratos celebrados por adesão. Para os autores citados:

Contratos negociados ou contratos de indústria são preparados e revistos conjuntamente por um grupo que deveria refletir os interesses de ambas as partes contratantes. Contratos de adesão, por outro lado, são redigidos com intuito de representar somente os interesses de uma parte e impostos à outra em termos de 'pegar ou largar'. (tradução nossa)

Nesse sentido, existem relevantes formulários, ou contratos-tipo, cuja redação é patrocinada por organismos internacionais, como UNCITRAL ${ }^{32}$ e FIDIC $^{33}$, e por organismos de âmbito nacional, especialmente nos países de sistema da common law, como, na Grã-Bretanha, RIBA/JCT ${ }^{34}$ e $\mathrm{ICE}^{35}$, e, nos Estados Unidos, os formulários

\footnotetext{
${ }^{30}$ Bessone , D.; Do Contrato - Teoria Geral, Rio de Janeiro, Forense, $3^{\text {a }}$ ed. 1987, p. 78.

31 Netto, A. et al., The Contra Prefeerentem Rule and Standard Forms of Construction Contracts, International Construction Law Review, vol. 19, part 3, julho 2002, p. 387.

${ }^{32}$ Legal Guide on Drawing up International Contracts for the Construction of Industrial Works, op. cit..

${ }^{33}$ Fédération Internationale des Ingénieurs-Conseils, com sede em Genebra.
} 
elaborados por $\mathrm{AIA}^{36}$ e $\mathrm{EJCDC}^{37}$, sendo freqüente sua utilização nos demais países da tradição jurídica anglo-americana, como Canadá, Austrália e Nova Zelândia. Vale notar que inclusive Malásia, Cingapura e Hong Kong lançam mão intensivamente desses contratos-tipo - muito embora esses países e território, respectivamente, não possam ser reconhecidos como pertencentes exclusivamente à tradição da common law, vez que mesclam outras tradições, como a islâmica - no caso de Malásia e Cingapura - com a common law.

Segundo explicam Bruner e O’Connor ${ }^{38}$, por mais de cem anos, o "santo graal" da indústria de construção norte-americana tem sido a alocação eqüitativa de riscos e atribuição de responsabilidades, por intermédio da generalizada utilização de contratos-tipo, ou modelos uniformes, amplamente aceitos.

De acordo com os autores citados, no século XIX, havia nos Estados Unidos a rígida aplicação do princípio pacta sunt servanda, também designado de princípio da "santidade dos pactos", pelo qual "um acordo a preço fixo fazia com que qualquer risco de construção não expressamente alocado pelo contrato ao dono da obra, permanecesse sob responsabilidade do empreiteiro"39. Assim, até que as doutrinas das condições contratuais implícitas fossem reconhecidas pelos tribunais norte-americanos, no início do século XX, a alternativa existente para os empreiteiros era o exaustivo detalhamento e a cuidadosa alocação de riscos e responsabilidades no contrato ${ }^{40}$. Essa

\footnotetext{
${ }^{34}$ The Royal Institute of British Architects/Joint Contracts Tribunal.

${ }^{35}$ Institution of Civil Engineers.

${ }^{36}$ The American Institute of Architects.

${ }^{37}$ Engineers Joint Contract Documents Committee.

${ }^{38}$ Bruner, P e O’Connor, Jr, P.; Bruner \& O’Connor on Construction Law, West Group, 2002, vol. 2, § 5:1, pp. 11-13

${ }^{39}$ Bruner, P e O’Connor, Jr, op. cit., p. 11

${ }^{40}$ Ferrarese, M; Il Diritto al Presente - Globalizzazione e Tempo delle Istituzione, Il Mulino, Bolonha, 2002, p. 88,. A autora correlaciona a extensão da tendência norte-americana a redigir cláusulas detalhadas à tendência de subtrair a interpretação contratual dos tribunais em função da "de uma longa tradição da common law que vedava incluir no contrato sanção por inadimplemento" (tradução nossa). Como visto acima, essa tendência decorria antes da aplicação do princípio da santidade dos pactos:
} 
tendência à utilização de contratos-tipo minuciosamente detalhados, decorria da experiência que se consolidava pela prática empresarial da engenharia e arquitetura, incorporada, pouco a pouco, aos modelos uniformes contratuais.

Finalmente, em 1888, o A.I.A., que indiretamente representa o interesse dos donos de obra - já que os arquitetos preparam em favor dos primeiros o projeto básico e as especificações ${ }^{41}$ de obra - e a National Association of Builders, predecessora da Associated General Contractors of America, representando o interesse dos empreiteiros, co-patrocinaram o assim chamado "Uniform Contract" ${ }^{\text {, }}$, que passou por inúmeras revisões e reedições, sendo acompanhado, nesse longo trajeto, pela publicação de vários outros formulários. Ainda hoje, os formulários-padrão do A.I.A. são os documentos mais amplamente usados na construção civil privada norte-americana ${ }^{43}$, sendo que o segmento que mais utiliza tais formulários é o da contratação entre empreiteiro principal e subcontratados.

O Brasil não conta com contratos-tipo ou formulários de amplo uso e aceitação, como os EUA e demais países integrantes do sistema da common law. Pode-se dizer que as grandes obras têm seus contratos principais intensamente negociados entre dono da obra e empreiteiro principal, ou consórcios de empresas do ramo, enquanto que, no relacionamento entre este e seus subcontratados, adotam-se minutas-padrão, geralmente elaboradas pelo próprio empreiteiro.

Em publicação recente, em que juristas de vários países comentam a aplicação dos formulários publicada pela FIDIC em vista dos ordenamentos locais,

estremamente dettagliati, mentre risponde all'intento di sottrarre l'interpretazione contrattuale alle corti, segna il distacco da una lunga tradizione di common law che vietava di includere nel contratto sanzione per l'inadempimento.

${ }^{41}$ Bruner, P e O’Connor, Jr, op. cit., §5:8, p. 29.

${ }^{42}$ Parker and Adams, The A.I.A. Standard Contract Forms and the Law (1954), apud, Bruner, P e O'Connor, $\mathrm{Jr}$, op. cit., $\S 5: 1$, p. 12.

${ }^{43}$ Bruner, P e O’Connor, Jr, op. cit., §5:8, p. 29. 
Bellegarde Nunes, Alvarenga, Réa e Castejón ${ }^{44}$ confirmam que: "Não há modelos específicos de contrato mesmo para obras públicas" (tradução nossa) no Brasil.

A explicação para a ausência de contratos-tipo nas áreas de engenharia e arquitetura talvez se deva fundamentalmente às características do setor de construção civil, engenharia e arquitetura brasileiro. Caso se fizesse um paralelo com os EUA, observar-se-ia que o equivalente à aceitação das cláusulas implícitas ${ }^{45}$ só se deu, no Brasil, em 1930. Naquela época, anota Arnoldo Medeiros da Fonseca ${ }^{46}$, verificou-se a primeira decisão, do então juiz e futuro Ministro do Supremo Tribunal, Nelson Hungria, que reconheceu a aplicabilidade da cláusula rebus sic stantibus a um caso concreto. A sentença, no entanto, veio a ser reformada em instância superior, embora pareça ser a precursora de muitas outras que vieram a reconhecer sua aplicabilidade. Dessa forma, pelo menos até os anos 1930, o princípio da santidade dos pactos era também estritamente observado no Brasil, inclusive por Castro Magalhães, J. X. Carvalho de Mendonça e Orozimbo Nonato ${ }^{47}$ e, no entanto, não se observava qualquer esforço de sistematização de minutas-padrão de contrato de empreitada.

Evidentemente, não se pode desconsiderar que o sistema jurídico da common law, em vista da ausência de definições legais e normas dispositivas previstas em lei em sentido formal, favorece o detalhamento de cláusulas contratuais e estabelecimento de definições. Certamente, o sistema do direito civil contribui de forma relevante, ainda que não determinante, para o afastamento da adoção de contratos-tipo como os aqui comentados. Nesse sentido, Huet ${ }^{48}$ nota que, exceto na França, onde existe regulamentação sobre construção imobiliária bastante elaborada, (ainda que não se possa considerar um conjunto industrial uma obra imobiliária) as legislações sobre o louage d'ovrage são, ao contrário, bem pouco desenvolvidas.

\footnotetext{
${ }^{44}$ Bellegarde Nunes et al., capítulo sobre o Brasil do livro FIDIC-Na Analysis of International Construction Contracts, ed. geral Knutson, R.; Kluwer Law International e International Bar Association, Haia, 2005, p. 1.

${ }^{45}$ Que, naquele país, passaram a ser incorporadas à jurisprudência somente no começo do século XX, como notado acima.

${ }^{46}$ Fonseca, A.; Caso Fortuito e Teoria da Imprevisão, Forense, Rio de Janeiro, $3^{\mathrm{a}}$ ed., 1958, p 310.

${ }^{47}$ Fonseca, A.; op. cit. , p 302.

${ }^{48}$ Huet, J., Traité de Droit Civil- Les principaux contrats spéciaux ; Paris, L.G. D. J. ; 2ª ed.,, 2001, p. 1543.
} 
Frilet $^{49}$, em recente relato, também mostra grande ceticismo em relação à aplicação de contratos-tipo, como os produzido pela FIDIC, na França e nos países francófonos. Relata que, nos sistemas de direito civil, a responsabilidade do construtor-empreiteiro sempre foi estabelecida de maneira extensiva, inclusive com a previsão do dever de informar, tendo ficado estabelecido que a obrigação do empreiteiro é de resultado e os contratos geralmente são celebrados a preço fixo.

$\mathrm{Na}$ Alemanha, Rosener e Dorner ${ }^{50}$ relatam que o contrato de construção é considerado um tipo especial de contrato de obra (Werkvertrag), regulado pelos $\S \S 631$ a 651 do código civil alemão (BGB-Bürgerliches Gesetzbuch), mas, diferentemente da França, a Alemanha faz uso extensivo de um contrato-tipo denominado Verdingungsordnung für Bauleistungen ${ }^{51}$, ou simplesmente "VOB". O VOB, que não tem força de lei e tem sempre sua utilização sujeita a acordo, é de uso compulsório quando se trata de obras contratadas por entes públicos, explicam os autores ${ }^{52}$, muito embora seja amplamente utilizado entre particulares. Assim, na Alemanha, ao contrário dos países de tradição de Direito Civil francesa, usa-se extensivamente um contrato-tipo, ou modelo uniforme de contrato de construção ${ }^{53}$.

${ }^{49}$ Frilet, Marc ; capítulo sobre a França do livro FIDIC-An Analysis of International Construction Contracts, editor geral Knutson, R.; Kluwer Law International e International Bar Association, Haia, 2005, p. 87-126.

${ }^{50}$ Rosener, W. e Dorner, G. ; capítulo sobre a Alemanha do livro FIDIC-An Analysis of International Construction Contracts, editor geral Knutson, R.; Kluwer Law International e International Bar Association, Haia, 2005, p. 79-86.

51 Em tradução livre, a partir do inglês, Procedimentos de Contratos de Construção ou Regras de Adjudicação para Trabalhos de Construção.

${ }^{52}$ Op. cit., pp. 90-91.

${ }^{53}$ A VOB é um conjunto de cláusulas, mais precisamente de condições gerais, referentes a contratos de construção. Essas regras foram elaboradas pela Comissão Alemã para Adjudicação e Contratos (DVA). A constituição dessa comissão deriva de uma associação que reúne representantes do setor imobiliário e do setor público, que, conjuntamente, trabalham na elaboração de regras adequadas ao desenvolvimento do mercado de construção.

A VOB é composta de três partes: "A", "B" e "C". Na parte "A", encontram-se as regras para a adjudicação de contratos de construção por entidades públicas. Na parte "B”, estão as condições contratuais gerais para a execução de trabalhos de construção. E, finalmente, a parte "C" contém condições técnicas gerais para a execução de trabalhos de construção.

Enquanto a aplicação da VOB/A é obrigatória para a adjudicação de contratos públicos, a VOB/B só é aplicável, na forma de condições gerais, quando aceita expressamente pelas partes. Se aceita a VOB/B, automaticamente inclui-se no contrato a VOB/C. Esta, por sua vez, pode também ser expressamente aceita, independentemente a aplicação da $\mathrm{VOB} / \mathrm{B}$.

Já foram editadas diversas versões da VOB, a primeira em 1926. Mais recentemente, o texto sofreu alterações mais significativas, em razão da emissão de diretivas da União Européia, e também de modo a se 
Embora a utilização de modelos uniformes de contrato pelos países da common law também se explique pelas peculiaridades do sistema jurídico adotado, é certo que seu uso poderia ser muito mais disseminado, uma vez que sua função não se restringe a suprir as demandas da disciplina consensual posta por esse sistema. Ao contrário, como visto acima, os contratos-tipo de engineering têm três funções essenciais: a) a de planejamento operacional da obra, bem como da disciplina convencional específica; b) a de ser instrumento de sedimentação da experiência técnica e jurídica aplicável aos contratos de engineering e; c) até como decorrência das duas primeiras, tornar o contrato autocontido.

As funções acima citadas produzem reflexos na disciplina convencional do contrato de engineering relevantes ao presente trabalho, na medida em

adequarem à reforma do direito das obrigações de 2001. A última versão editada data de 2006. Existindo diversas edições, se as partes não fizerem referência à versão aplicada, entende-se que seja a última, pois particulares podem decidir livremente por qualquer delas aplicar. Já entidades públicas devem adotar a versão mais recente.

A adoção da VOB é regida pelas regras do BGB sobre condições gerais de negócios (AGBG), nos $\S \S 305-310$, que cuidam da proteção e controle de condições gerais, especialmente em favor do consumidor, contra regras obscuras, abusivas e contraditórias. No caso de contratos entre empresas e com órgãos públicos, existem regras especiais, que limitam o poder de controle do conteúdo das condições gerais.

As partes, se decidirem pela aplicação da VOB, podem incluí-la seja no próprio texto do contrato, seja por mera referência a esta. Importante é que a outra parte tome conhecimento de tais regras (ou lhe seja dada a possibilidade de tomar conhecimento) e as aceite expressamente.

As partes podem adotar a VOB em sua integralidade ou realizar alterações a cláusulas específicas. Entende-se que a adoção integral, sem ressalvas, das regras da VOB excluiria a possibilidade de se realizar o controle do conteúdo de cláusulas específicas contidas nela, na forma prevista no BGB, pois a regra teria sido aceita como um todo, coerente e sistemático. Isso se explica, pois o controle de conteúdo previsto no BGB visa a proteger a parte à qual foram impostas as condições gerais de condições abusivas. Porém, no caso da VOB, a existência de uma cláusula onerosa para uma das partes não significa abusividade no seu conjunto.

Decisão do Bundesgerichtshof (BGH) de 22.01.2004 determinou que qualquer alteração em alguma das cláusulas-padrão da VOB possibilitaria o controle do conteúdo de todas as condições gerais ali contidas. A dificuldade que pode decorrer disso é que o BGB trata da possibilidade de controle do conteúdo apenas em favor daquele que foi submetido à aplicação das condições gerais, ficando integralmente aplicáveis as disposições àquele que as introduziu. Assim, uma alteração poderia levar à completa desvirtuação das condições aceitas pelas partes, tendo em vista que o controle das cláusulas seria feito apenas em favor de um dos contratantes. Isso poderia ser resolvido na medida em que ambas as partes declarassem expressamente quererem a aplicação da VOB, de modo que esta não seja imposta por nenhuma das partes à outra.

Fontes: http://www.wuw-anwaltskanzlei.de/Baurecht/Baurecht-VOB/baurecht-vob.html e http://www.jura.uni-marburg.de/zusatzqualifikationen/baurecht/dokumente/SkriptVOBundAGB2.doc ambos consultados em 16.12.06 e Rosener, W. e Dorner, G., op. cit., passim. 
que os diversos contratos-tipo fixam cláusulas específicas a respeito do desequilíbrio econômico-financeiro do contrato e superveniência contratual. 


\subsection{DEFINIÇÃO DOS CONTRATOS DE ENGINEERING}

A elaboração da definição do contrato de engineering é problemática, tendo em vista que, segundo Alpa e Fusaro ${ }^{54}$, os elementos a serem considerados e os aspectos descritos devem ser bastante gerais e compreensivos para poder abarcar todas as espécies de engineering. Nesse sentido, ainda segundo esses autores, talvez uma definição obedeça mais a exigências sistemático-didáticas, do que a exigências conceituais, tendo em vista que, na prática, os tipos desses contratos recebem diversas especificações, e os próprios conteúdos são diversamente recortados. Daí porque preferem se referir ao engineering, genericamente, no plural, como "contratos de engineering", que compreendem espécies e subespécies.

Se as definições têm por função delimitar o definido ${ }^{55-56}$, geralmente de pouca utilidade têm sido as definições de contrato de engineering, já que, como diz o próprio Alpa, acima, os elementos a serem considerados na formulação de tal definição e os aspectos descritos devem ser bastante gerais. No entanto, nota Ferraz Jr. ${ }^{57}$ - ao

\footnotetext{
${ }^{54}$ Alpa, G.; Fusaro, A., I Contratti di Engineering, in Trattato di Diritto Privato, direto da Pietro Rescigno, vol . 11, tomo III, $2^{\mathrm{a}}$ ed., Turim: UTET, 2000, p. 171.

55 Telles Junior, G, Tratado da Conseqüência - Curso de Lógica Formal, São Paulo, Ed. Juarez de Oliveira,

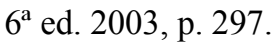

${ }^{56}$ Como diz Comparato em Comparato, F.; O Poder de Controle na Sociedade Anônima, Forense, Rio de Janeiro, $3^{\text {a }}$ ed., 1983, pp.83, 84-85.
}

Uma das grandes conquistas da ciência jurídica contemporânea foi a de superar o ingênuo 'essencialismo' das definições, entendidas como se referindo a 'naturezas jurídicas' eternas e imutáveis [...] A nova ciência jurídica não despreza, evidentemente os conceitos e as definições, como instrumentos indispensáveis à aplicação do direito, mas considera tais instrumentos sempre perfectíveis e provisórios, em função da constante observaçãohistórica da vida humana em sociedade.

${ }^{57}$ Ferraz Jr., T. S.; Introdução ao Estudo do Direito, São Paulo, Ed. Atlas, 4 a ed., 2003, p. 87:

Ao contrário das teorias zetéticas, as dogmáticas, preocupadas com a decidibilidade dos conflitos, não cuidam de ser logicamente rigorosas no uso de seus conceitos e definições, pois para elas o importante não é a relação com os fenômenos da realidade (descrever os fenômenos), mas sim fazer um corte na realidade, isolando os problemas que são relevantes para a tomada de decisão e desviando a atenção dos demais. 
mencionar que as definições jurídicas seguem outro perfil de rigor formal que não o puramente lógico - como as definições jurídicas não se destinam a descrever a realidade, mas dela fazer um corte a fim de se isolar problemas, pode-se empreender a elaboração da definição dos contratos de engineering com o fim de buscar resposta ao problema de sua qualificação.

Nesse sentido, os autores têm envidado esforços para alcançar razoável definição do contrato. Alpa ${ }^{58}$, por exemplo, define-o como:

[...] contrato em que uma parte (normalmente uma empresa), se obriga frente à outra a elaborar um projeto, de natureza industrial, arquitetônica, urbanística e eventualmente a realizá-lo, ou mesmo realizar projeto elaborado por outra empresa, dispondo-se também, se convencionado, a desenvolver prestações acessórias de assistência técnica, recebendo a título de contraprestação soma em dinheiro, integrada (ou substituída por) royalties, ou participação nos resultados da atividade empresarial desenvolvida em seguida à realização do projeto. (tradução nossa).

Por sua vez, Rosella Cavallo Borgia, em sua monografia sobre o contrato de engineering, define-o de modo mais detalhado, como $^{59}$ :

$\mathrm{Na}$ verdade os traços especificamente caracterizadores do novo modelo contratual são individuados na complexidade da atividade desenvolvida, inclusive de parte de sujeitos dotados de formação profissional correspondente àquela do engenheiro e do arquiteto e na integração recíproca das próprias atividades ordenadas e confluentes ao resultado final articulado.

${ }^{58}$ Alpa, G. e Fusaro, A., I contratti di engineering, in "Trattato di Diritto Privato", direto da Pietro Rescigno, vol . 11, tomo $3^{\circ}$, segunda ed., UTET, Torino 2000, p. 172.:

[...] contratto con il quale una parte (normalmente un'impresa) si obbliga, nei confronti dell'altri ad elaborare un progetto, di natura industriale, architettonica, urbanistica, ed eventualmente a realizzarlo, ovvero a dare realizzazione a progetti da altre imprese elaborati, provvedendo anche, se ciò sia convenzionalmente pattuito, a svolgere prestazioni accessorie di assistenza tecnica ricevendo a titolo di corrispettivo una somma in danaro, integrata (o sostituita) eventualmente da royalties, interessenze o partecipazioni agli utili dell' attività imprenditoriale avviata in seguito alla realizzazione del progetto.

59 Cavallo Borgia, R., Il Contratto di Engineering, Cedam, Pádua, 1992, p. 135:

Ed invero $i$ connotati specificamente caratterizzanti il nuovo modello contrattuale vanno individuati nella complessità dell'attività svolta, anche da parte di soggetti dotati di formazione professionale corrispondente a quella dell'ingegnere e dell'architetto e nella integrazione reciproca delle stesse attività poste in essere e confluenti nell'articolato risultato finale. L'engineering risulta in tal modo rispondente alle esigenze di integrazione operativa in una sfera progettuale ed esecutiva modernamente intesa e funzionale a formulare nuove strategie di intervento in relazione alle tendenze evolutive del mercato interno ed internazionale. 
O engineering resulta, desse modo, adequado às exigências de integração operacional em uma esfera projetística e executiva modernamente assente e funcional para formular novas estratégias de intervenção em relação às tendências evolutivas do mercado interno e internacional. (tradução nossa).

A formulação de Cavallo Borgia põe em evidência a complexidade sempre presente no contrato de engineering, justamente porque resulta da integração de várias disciplinas de engenharia e arquitetura, bem como financeira e administrativa. Ressalta também que a qualidade do sujeito contratante, que deve ser dotado de formação técnica apropriada, é traço distintivo importante desse contrato. No entanto, mais um elemento figura na caracterização desse contrato, qual seja, a presença do risco na consecução do objeto. Esses três elementos, complexidade, risco e qualificação da parte contratada são essenciais à qualificação contratual, muito embora não sejam independentes ou autônomos entre si, mas antes mutuamente indutores, ora com pesos similares, ora com pesos diferentes entre si, na composição não só do regulamento contratual, mas também durante o iter de sua execução. É o que se verá abaixo.

\subsubsection{Da necessária presença de pessoa que exerça a atividade empresarial de engenharia}

De fato, na tipificação do contrato de engineering, é essencial a figura da empresa de engenharia, devidamente habilitada, como um dos pólos contratantes. Essa nota caracteriza determinantemente o contrato de engineering e é uma resposta, em termos de qualificação do sujeito que recebe a incumbência de realizar a obra, às duas outras notas características do contrato, que são o risco e complexidade.

No Direito Italiano, De Nova ${ }^{60}$ afirma claramente sua opinião no sentido que os dados atinentes ao sujeito contratante assumem relevância distintiva na tipificação de vários contratos, como no caso dos contratos bancários ou de seguros, chegando ilustrar seu raciocínio - sempre se referindo ao ordenamento italiano - como sendo a organização empresarial do empreiteiro o traço que marca a distinção típica entre o

\footnotetext{
${ }^{60}$ De Nova, G.; Il Tipo Contrattuale, Cedam, Pádua, 1974, pp. 97 e ss.
} 
contrato de empreitada ${ }^{61}$ e o de obra ${ }^{62-63}$. Ou seja, um dos caracteres distintivos do tipo pode ser a habilitação ou a particular condição organizacional do sujeito.

Com efeito, não se concebe o contrato de engineering sem a figura do arquiteto ou engenheiro-empresário. No direito comparado, especialmente na Itália, a evolução do engineering é sempre marcada pela discussão sobre a licitude do exercício da engenharia ou arquitetura sob a forma empresarial ${ }^{64}$. Solucionada a dúvida e amplamente aceita a organização empresarial da engenharia, decorrem do desenvolvimento dessa atividade os contornos atuais do contrato de engineering. Ou seja, raciocinando-se tipologicamente ${ }^{65}$ e seguindo as notas características descritas por Cavallo Borgia, acima, tem-se que o contrato de engineering possui ao menos três notas de maior importância: a

\footnotetext{
${ }^{61}$ Art. 1655 do Código Civil italiano.

${ }^{62}$ Art. 2222 do Código Civil italiano.

${ }^{63}$ Interessante notar que Pontes de Miranda critica, por artificial, a distinção adotada pelo Código Civil italiano:

O direito brasileiro, com a fixação da terminologia ('empreitada') evita que se discorra sôbre a diferença entre locação de serviços e empreitada. Por outro lado, abstraiu da diferença entre empreitada prevalentemente pessoal e empreitada por empresa, evitando artificialidade que vai a ponto de se falar de empreitada e de contrato de obra como se a qualidade do sujeito outorgante pudesse mudar a estrutura do negócio jurídico. Cp. Código Civil italiano, arts. 1655 e 2.222." (Pontes de Miranda, Tratado de Direito Privado, Tomo XLIV, Revista dos Tribunais, São Paulo, 1984, $3^{\mathrm{a}}$ ed., $2^{\mathrm{a}}$ reimp., p. 378).
}

${ }^{64}$ Vide Alpa, G.; Fusaro, A., I Contratti di Engineering, cit. , pp. 178-184; Cavallo Borgia, R., Il Contratto di Engineering, Cedam, Pádua, 1992, p. 135, pp. 5-10; Lapertosa, F. L'Engineering, Milão, Giuffrè, 1993, pp 69-115; De Nova, G; Nuovi Contratti, pp. 67-68. Nos EUA, vide Stitt, W. B; . cit. p. 972.

${ }^{65}$ Larenz, K.: Metodologia da Ciência do Direito, pp. 260-261:

Um conceito está fixado por meio da sua definição, de tal modo que haja de aplicar-se a um evento concreto ou situação de facto «só quando e sempre que» se possam nele encontrar o conjunto das notas características da definição. Esta proposição não vale para o tipo. As notas características indicadas na descrição do tipo não precisam, pelo menos algumas delas, de estar todas presentes; podem nomeadamente ocorrer em medida diversa. São com freqüência passíveis de gradação e até certo ponto comutáveis entre si. Consideradas isoladamente, só têm o significado de sinais ou indícios. O que é decisivo é, em cada caso, a sua conexão à realidade concreta. Se uma determinada situação de facto se pode ou não ordenar ao tipo é algo que não pode, nestes termos, ser decidido consoante contenha ou não todas as notas características tidas como imprescindíveis. Trata-se antes de se saber se as notas características tidas como «típicas» estão presentes em tamanho grau e intensidade que a situação de facto «no seu todo» corresponda à imagem fenoménica do tipo. O tipo não se define, descreve-se. Não se pode subsumir à descrição de tipo; mas pode-se, com a sua ajuda, ajuizar se um fenómeno pode ou não integrar-se no tipo. 
figura do empresário-engenheiro como parte integrante do contrato, o risco e sua complexidade.

\subsubsection{A complexidade do conteúdo e execução contratuais}

Já examinada a nota atinente à presença do arquiteto ou empresárioengenheiro em um dos pólos contratuais, vale tratar mais a fundo da nota de complexidade de seu objeto e de sua execução, que também é inerente aos contratos de engineering. Com o pragmatismo peculiar à casuística da common law - que também denomina os contratos de engineering de construction contracts - nos Estados Unidos da América já se disse que esses contratos são uma "raça animal distinta"

No entanto, dizer que contratos de engineering são complexos pouco esclarece o interessado no assunto se não se indica o que se entende por complexidade em relação ao contrato em si.

A própria noção de complexidade induz ao pleonasmo uma vez que a tarefa de explicar a complexidade é, efetivamente, complexa. Não por outra razão, diz Hetland, citando Lissac e Roos, que “o termo 'complexidade' é frequentemente usado para descrever o fato de que algo é complicado." ${ }^{67}$. Na mesma passagem, Hetland procura descrever a complexidade de forma mais abrangente sumarizando a visão de Eve et $a l^{68}$ :

66 Paul Hardeman, Inc. v. Arkansas Power \& Light Co., 380 F. Supp. 298, 317 (E.D. Ark. 974), apud, Bruner, P e O’Connor, Jr, P.; Bruner \& O’Connor on Construction Law, West Group, 2002, p.22, § 1:3:

[C]onstruction contracts are a separate breed of animal; and, even if not completely sui generis, still [the] law must be stated in principles reflecting underlying economic and industry realities. Therefore, it is not safe to broadly generalize. True, general principles of contract law are applied to construction contracts, but they are applied under different operative conditions. Care must be taken, then, not to rely too uncritically on such cases as those arising from the sale of real or personal property. And even within the larger rubric of "construction contracts," it is manifest that the law, if sensitive to the underlying realities, will carefully discriminate between, say, a contract to construct a home and a contract to construct a 50-story office building; between a contract to build a private driveway and a contract to construct an interchange on an interstate highway. This is what one would expect a priori; this is, generally, what one finds when he reviews the actual development of the law.

${ }^{67}$ Hetland, P. W, Uncertainty Management, in Appraisal, Risk and Uncertainty, Smith, N. editor; Thomas

Telford Publishing, Londres, 2003, p. 72. 
Complexidade não é a propriedade somente do número das partes componentes ou mesmo da direção de sua relação, mas da variedade de suas interações e assim a possibilidade de alinharem-se em muitas configurações diferentes.

Não importa quão amplo o número de componentes, se não houver potencial para os componentes interagirem, alinharem-se e se organizarem em configurações específicas de relacionamento, não há complexidade.

Mesmo que os componentes sejam organizados, mas dentro de tais arranjos completamente confinados que não sejam deixadas abertas outras possibilidades de variedade na inter-relacionamento, não há complexidade. Complexidade, dessa maneira, tem a ver com a inter-relacionalidade dos componentes, assim como sua liberdade de interagir, alinhar-se e se organizar em configurações relacionadas.

Quanto mais componentes e quanto mais maneiras pelas quais os componentes possam interagir, alinhar-se ou se organizar, maior é a complexidade. (tradução nossa).

Contratos de engineering são complexos porque envolvem inúmeras disciplinas e subdisciplinas de engenharia, arquitetura, economia, administração e mesmo várias disciplinas jurídicas, como direito das obrigações, reais, tributário, trabalhista, previdenciário, entre outras. Mais do que ponto de influxo de diversas áreas do conhecimento, no entanto, o contrato de engineering é complexo porque o número de variáveis que influenciam a execução de seu objeto é relativamente grande, em comparação com contratos mais simples.

\section{Engleston,. Posner e Zeckhauser ${ }^{69}$ consideram um contrato complexo} segundo visão multidimensional, ou, especificamente, segundo três dimensões do contrato:

${ }^{68}$ Hetland, P. W, op. cit., p. 73:

Complexity is not a property just of the number of component parts or even the direction of their relationship, but of the variety of their interactions and thus the possibility to align into many different configurations.

No matter how large the number of components, if there is no potential for components to interact, align, and organize into specific configurations of relationship, there is no complexity.

Even if components are organized, but within such completely confining arrangements that no further possibilities for variety in interaction are left open, there is no complexity. Complexity, therefore, has to do with the interrelatedness of components as well as their freedom to interact, align, and organize into related configurations.

The more components and the more ways in which components can possibly interact, align, and organize, the higher complexity.

69 Eggleston, K Posner, E. e Zeckhauser, R, Simplicity and Complexity in Contracts, http://papers.ssrn.com/paper.taf?abstract_id=205391, p. 7. - verificado em 21.07.2006:

We treat complexity as a multidimensional concept that can only be judged relative to the contracting environment. Specifically, by "complexity," we refer to three dimensions of the contract: (1) the expected number of payoff-relevant contingencies specified in the contract; (2) the variance in the magnitude of the payoffs contracted to flow between the parties; and (3) the cognitive load 
"[...] 1) o número esperado de contingências relevantes relacionadas ao alcance das utilidades especificadas no contrato; 2) a variância na magnitude das utilidades contratadas para fluir entre as partes e 3) o grau de esforço cognitivo requerido para o entendimento do contrato. (tradução nossa)

A citação acima supõe reflexão mais extensa para sua contextualização. $\mathrm{O}$ uso da expressão "alcance das utilidades especificadas no contrato"70, encontra paralelo, na teoria contratual do sistema de direito civil, na expressão “cumprimento do objeto do contrato", tendo-se presente sua patrimonialidade ${ }^{71}$. Ou seja, o cumprimento do contrato traz em si resultados de ordem patrimonial para as partes contratantes, que se caracterizam, sempre no âmbito contratual, como utilidades.

Como diz Roppo ${ }^{72}$, "o território habitado pelo contrato é aquele das relações jurídicas patrimoniais". As relações jurídicas patrimoniais são aquelas suscetíveis de avaliação pecuniária ${ }^{73} \mathrm{e}$, portanto, economicamente referíveis. Essas relações vinculam-se, portanto, à satisfação de necessidades humanas, mediante troca ou criação de valor para ao menos um dos pólos da relação - valor que se confunde com utilidade, ou benefício que a parte aufere da relação, p.e., com a aquisição ao direito à contraprestação em vista do cumprimento de certa obrigação. Assim, posta a citação de outra maneira, poder-se-ia caracterizar um contrato como complexo quando: 1) houver elevado grau de incertezas, ou elevado número de contingências, quanto a seu cumprimento ou fruição das utilidades nele, contrato, previstas; 2) houver dispersão ou variabilidade ${ }^{74}$ entre a

required to understand the contract. Each component of complexity is measured along a continuum: contracts are more or less complex.

${ }^{70}$ A palavra payoff é de difícil tradução para o português. Neste trabalho, optamos por traduzi-la como "utilidade".

${ }^{71}$ Bessone, Darcy; Do Contrato - Teoria Geral, Rio de Janeiro, Forense, $3^{\mathrm{a}}$ ed. 1987, p. 6: “O contrato [...] conceitua-se como 'acordo de duas ou mais pessoas para, entre si, constituir, regular ou extinguir uma relação jurídica de natureza patrimonial."

72 Roppo, Vincenzo, Il Contratto, Milão, Giuffré, 2001, p. 5: “Il territorio abitato dal contratto è quello dei rapporti giuridici patrimoniali”.

${ }^{73}$ Mota Pinto, C.A., Teoria Geral do Direito Civil, Coimbra, Coimbra Editora, $3^{\text {a }}$ ed., 1990, p. 343 :

Só fazem parte do patrimônio as relações jurídicas susceptíveis de avaliação pecuniária; esta pecuniariedade pode resultar do valor de troca do direito, por este ser alienável mediante uma contraprestação, ou do valor de uso, traduzido em o direito, não sendo embora permutável, proporcionar o gozo de um bem, material ou ideal, que só se obtém mediante uma despesa.

${ }^{74}$ As palavras "dispersão" e "variabilidade" são algo imprecisas na representação do conceito - estatístico de variância, expressão usada na citação. No entanto, parecem adequadas ao contexto. 
magnitude das prestações e contraprestações na dinâmica ou fluxo de seu cumprimento (caso típico dos contratos cuja consecução do objeto contratual se desenvolva em ambiente de risco, ou aleatoriedade); e 3) quando o entendimento do conteúdo contratual demande conhecimento amplo ou profundo.

Note-se, ainda a respeito da citação de Engleston, Posner e Zeckhauser, que o contrato é visto de maneira dinâmica. Contingências ou incertezas em relação ao cumprimento do contrato somente se fazem presentes em contratos que não sejam instantâneos, ou seja, em contratos em que medeie certo período, maior ou menor, entre sua formação e cumprimento substancial. A relação contratual é antes sujeita às vicissitudes e incertezas do decurso do tempo, do futuro. Tempo que influi no cumprimento do contrato porque traz a incerteza, a contingência - e com ela, o risco.

Como é sabido, a contingência é noção explorada por Aristóteles, que diferencia o que é contingente, por se produzir no futuro, do que é necessário, por se verificar no presente, ou se ter produzido no passado, podendo-se, quanto ao necessário, afirmar-se se tal ou qual predicado é falso ou verdadeiro. Já o contingente pode se converter, no futuro, em falso ou verdadeiro com menor ou maior probabilidade ${ }^{75}$. Ou seja, é contingente aquilo que não se produz necessariamente, por se produzir no futuro.

Adicionalmente, como lembra Luhmann, "o que pode ocorrer no futuro também depende de decisões a se tomar no presente" ${ }^{76}$. É exatamente nesse prisma que se situa o contrato cuja execução se dá no futuro. As partes tomam a decisão de contratar, de fazer ou deixar de fazer algo para conformar, para influenciar eventos futuros. Entretanto, não existe controle total das partes sobre os acontecimentos futuros, já que o decurso do tempo traz a incerteza, ou contingência, seja em vista de alterações no ambiente

\footnotetext{
${ }^{75}$ Aristóteles, De Interpretatione [in Organon], Trad. Bini, Edson, Edipro, São Paulo, 1ª ed., 2005, p. 92:
}

Fica claro que nem tudo é ou se produz por necessidade. Há casos de contingência, com o que a proposição afirmativa não é mais verdadeira ou mais falsa do que a negativa. Constatamos que alguns casos, ademais, ao menos no que tange à maioria e ao mais comum, apresentam tendência numa certa direção, o que não os impede, não obstante, de poderem, ocasionalmente, surgir na outra direção ou direção mais esporádica.

${ }^{76}$ Luhman, Niklas, Risk - A Sociological Theory, New Brunswick (USA), Aldine Transaction Publishers, 2005, p. 16: "[...] what can occur in the future also depends on decisions to be made at the present." 
ou alterações no conhecimento que temos sobre o ambiente ${ }^{77}$. Mais do que isto, como ainda lembra o mesmo Luhmann ${ }^{78}$, o tempo altera o julgamento que temos sobre determinado fato, tornando mais dinâmica a abordagem que se faz da contingência.

Do ponto de vista contratual, as alterações objetivas do ambiente são basicamente tratadas pela teoria do caso fortuito e força maior, ou superveniência contratual. Já as alterações na compreensão que temos sobre o ambiente durante o iter contratual são englobadas pelas teorias da onerosidade excessiva, imprevisão, alteração das circunstâncias etc., tendo em vista que essas teorias consideram, além da alteração do ambiente em si, também as alterações do conhecimento subjetivo que se tem dele. Como ilustração, a incidência de um raio sobre a estrutura metálica de uma ponte pode ser evento de força maior que produz efeitos em relação ao contrato de construção da ponte. Mas esses efeitos são relativos. Se soubermos que o local em que se constrói a ponte recebe raios com grande freqüência, nossa incerteza epistemológica se reduzirá, possibilitando que se tomem medidas como a prévia instalação de pára-raios, ou uso de materiais de grande resistência a descargas elétricas. Ou seja, nosso conhecimento permite que condicionemos o cumprimento contratual de maneira a neutralizar as conseqüências trazidas pela queda de raios. No entanto, se instalamos o pára-raios e desconhecemos algum fator do solo, por exemplo, que pode tornar o pára-raios inoperante, estamos diante de uma conseqüência que não pôde ser neutralizada por nossas ações previamente engendradas.

Por outro lado, ainda explorando o exemplo da queda de raios, seria possível que conhecêssemos as probabilidades de queda de raios no local de construção da ponte. Digamos que soubéssemos que, no referido local, a probabilidade de queda de raios é de um raio a cada cem anos. Podemos, então, optar por considerar a ocorrência de raios e, por preocupação em salvaguardar a conclusão da obra, incluir o uso de artefatos de prevenção aos efeitos danosos eventuais. Sendo este um suposto da contratação (uma e

${ }^{77}$ Vide McCann, Jr., C. R., Conceptions of Probability, in The Elgar Companion to Economics and Philosophy, ed. By Davis, J. B., Marciano, A e Runde, J.- Edward Elgar, Cheltenham, 2004, p. 459:

The term 'uncertainty' is somewhat ambiguous, and is often employed in two quite different ways: in reference to the manifest variability of the environment, and to our apprehension of that environment. In other words, there is a distinction between the occurrence and non-occurrence of an event, and our belief that the event will occur. The former is ontological, the latter epistemic.

${ }^{78}$ Luhman, Niklas, Risk-A Sociological Theory, idem. 
outra parte acordaram em empregar os artefatos e, por conseqüência, arcar com os custos respectivos), diante da inusitada queda de raio, maiores conseqüências patrimoniais não haveria, já que o término da obra estaria resguardado. No entanto, diferente seria se nossos registros históricos, que remontam a noventa anos, digamos por hipótese, jamais registraram a queda de raios, tendo sido impossível saber, à época da construção, que raios podem cair naquela região uma vez a cada cem anos. Certamente, a ausência de conhecimento a respeito de certa probabilidade gerará efeitos sobre a utilidade patrimonial que as partes auferirão pela construção da ponte, já que maiores recursos econômicos serão necessários para a conclusão do projeto. A contingência, assim, é reflexo direto do conhecimento humano.

A engenharia, como área do conhecimento científico e tecnológico, é pródiga no enfrentamento de contingências como a acima exemplificada. Tantos os acidentes naturais, como raios e solos de composição desconhecida, como o desconhecimento ainda existente do comportamento de materiais e demais insumos para a conclusão de uma obra, multiplicam o número de contingências e incertezas, tornando o contrato complexo sob os três aspectos descritos por Engleston, Posner e Zeckhauser.

Nesse sentido, Henry Petroski ${ }^{79}$, depois de lembrar que a engenharia tem elementos de ciência, mas também de arte, diz que:

O projeto de engenharia compartilha certos característicos com a formulação de teorias científicas, mas em vez de levantar hipóteses sobre o comportamento de um dado universo, seja de átomos, abelhas ou planetas, engenheiros levantam hipóteses sobre montagens de concreto e aço que eles ordenam dentro de um mundo de sua própria concepção. Assim, cada novo edifício ou ponte pode ser considerado uma hipótese em si.

A imagem de Petroski refere-se à engenharia como arte, ou ciência, da concretização de hipóteses. Se o cientista testa as hipóteses previamente formuladas para descrever seu comportamento ou resultado, aumentando, com isso, o conhecimento humano sobre o universo, o engenheiro formula hipóteses, mas não se limita a descrever seu comportamento e aplicação, concretizando obras humanas e modificando a natureza.

${ }^{79}$ Petroski, H.; To Engineer is Human: The Role of Failure in Successful Design, New York, Vintage Books, 1992, p. 43. 
Embora não seja um risco exclusivo do exercício da engenharia, que emprega tecnologias que não podem ser previamente testadas - já que as obras de grande porte geralmente não podem ser submetidas a provas antes de realizadas em definitivo, ainda que modelos em escala reduzida sejam desenvolvidos - o risco tecnológico torna mais difícil o cálculo da probabilidade de certo empreendimento, uma vez que, como dizem Mol e Law ${ }^{80}$, "tecnologias de larga escala geralmente surgem a partir de experiências de laboratório, mas o processo de translação [para o produto final, ou obra] é capcioso porque experimentos laboratoriais são técnicas simplificatórias.”.

De fato, risco e complexidade são imanentes ao projeto de engenharia, ainda que em diferentes graus. Como explica Hetland ${ }^{81}$, pode-se classificar tipos de projetos por níveis de complexidade:

\begin{abstract}
Projetos tipo "status-quo"
Projetos, em grande número, podem ser triviais no sentido de que sabemos o que e como fazer. Trata-se apenas de um projeto a mais, similar aos que têm sido desenvolvidos por décadas. [...] $\mathrm{O}$ aprendizado sobre eles é apenas incremental [e] a ênfase está em superar ou explorar as melhores práticas, evitando-se erros como retrabalhos, excesso de demora e fenômenos similares que afetam tempo e produtividade.

As estratégias de suprimentos de melhoria de valor aplicáveis aos projetos tipo status-quo são tipicamente lineares, as estruturas de contrato são hierarquizadas e os processos de trabalho são seqüenciais. A filosofia geral consiste em reduzir incertezas ao mínimo antes que contratos sejam celebrados. O trabalho do projeto é dividido em contratos de engenharia e construção separados. Nenhum contrato de construção é assinado a menos que a definição compreensiva do escopo de trabalho tenha sido produzida. Uma política de não-alteração (e, assim de não-aprendizado) é executada.[...] (tradução nossa).
\end{abstract}

Projetos do tipo status-quo ocorrem rotineiramente, incorporam baixo nível de incerteza porque são praticamente reproduções de outros projetos. Pretende-se, com o projeto, por exemplo, construir uma casa simples, em terreno e com materiais conhecidos. Não há grandes novidades e os riscos decorrem de um desvio ou falha em procedimentos já experimentados. Muito maior complexidade é encontrada no que Hetland chama de "projetos tipo desenvolvimento"

\footnotetext{
${ }^{80}$ Law, J. e Mol, A.; Complexities; An Introduction, in Complexities: Social Studies of Knowledge Practices, 2006 (segunda impressão) Duke University Press, Durham e Londres, , p. 3;

${ }^{81}$ Hetland, P. W, Uncertainty Management, in Appraisal, Risk and Uncertainty, Smith, N. editor; Thomas Telford Publishing, Londres, 2003, p. 80.

${ }^{82}$ Idem, pp. $81-82$
} 


\begin{abstract}
Projetos tipo desenvolvimento
Para que estratégias "B" (objetivos funcionais e processos-guia) tenham sucesso, o aprendizado é essencial. As estratégias "b" não visam a reduzir a incerteza, a incerteza é, antes, disposta como maneira de acréscimo de valor. Os objetivos do projeto não são completamente determinados; são frequentemente expressos em termos de requisitos funcionais. Além do mais, os processos de trabalho não são prescritivos; documentos de orientação mais abertos são usados. Em suma, as estratégias "B" encorajam fornecedores a selecionar seus próprios objetivos e procedimentos dentro de amplos dizeres providos pelo cliente.

Como exemplo, essa estratégia pode ser implementada quando a ambição do cliente (e, esperançosamente, o objetivo comum) seja melhorar o custo do projeto em $40 \%$ pela aplicação dos princípios Norsok (um desafio de projeto semi-fechado, semi-aberto) [...] Isso implica que o projeto requer conhecimento e experiência presentemente desconhecida à organização. Assim, a organização terá ou que iniciar processos internos de aprendizado ou adquirir conhecimentos suficientes e complementares de parceiros. Em outras palavras, a transferência intra ou interorganizacional de aprendizado ou experiência é um fato crítico de sucesso.
\end{abstract}

Para a adoção dessas estratégias de processos que Hetland chama de "desenvolvimento", o autor distingue duas escolas: a do EPC (engineer, procure and construct, ou faça a engenharia, adquira os suprimentos e construa) e a PAHA (project ad hoc alliance, ou aliança ad hoc de/para projeto) - ambas amplamente adotadas no Brasil, com os grandes projetos contratados por empreitada integral ${ }^{83}$ (também conhecidos como contratos turnkey), ou contratos entre dono da obra e consórcio de empresas.

Hetland diz que o EPC oferece as vantagens do isolamento dos fornecedores de influências causadas pelo dono da obra, da possibilidade de maior integração entre as áreas de engenharia e construção da empresa. Nesse sentido, a vantagem que permeia o EPC é a integração de conhecimentos, já que, “em geral, as empresas são consideradas como possuidoras de certas vantagens como instituições aptas a suportar mecanismos de integração de conhecimentos". ${ }^{84}$.

${ }^{83}$ A Lei no 8.666, de 21.6.1993 define, em seu artigo 60, inciso VIII, alínea "e" a empreitada integral como:

empreitada integral-quando se contrata um empreendimento em sua integralidade, compreendendo todas as etapas das obras, serviços e instalações necessárias, sob inteira responsabilidade da contratada até a sua entrega ao contratante em condições de entrada em operação, atendidos os requisitos técnicos e legais para sua utilização em condições de segurança estrutural e operacional e com as características adequadas às finalidades para que foi contratada

${ }^{84}$ Idem, p. 82. 
Em paralelo ao EPC, surge a escola PAHA, que, no Brasil, é basicamente desenvolvida por intermédio dos consórcios entre empresas. Quando se adota essa estratégia de abordagem de certo projeto, as empresas se consorciam, ou, em senso lato, associam-se temporariamente com o fim de reunir conhecimentos, capacidades e tecnologias complementares, alavancando os processos de criação de valor dos projetos. $\mathrm{O}$ sucesso da PAHA, nota Hetland, "é sensível ao grau de confiança mútua e respeito entre os parceiros na aliança." 85

Vale deixar claro, entretanto, que não existe oposição funcional entre PAHA e EPC, que são processos combináveis entre si, inclusive. Nada impede - aliás é freqüente - que contratos EPC sejam celebrados entre o dono da obra e um consórcio, ou associação de empresas. A distinção feita por Hetland, acima, é exclusivamente didática, permitindo divisar as formas de lidar com os riscos envolvidos na execução de projetos.

Em adição ao aspecto de complementaridade de conhecimentos enfatizado por Hetland em relação às alianças formadas para desenvolvimento de projetos, é importante ressaltar que as associações temporárias de empresas, como os consórcios, visam também à divisão dos riscos envolvidos no projeto. Projetos do tipo “desenvolvimento", por envolverem novas tecnologias e, geralmente, tecnologias não só de produto, mas de processo, como as tecnologias tendentes à redução de prazos de construção com utilização de novos materiais ou técnicas, e também tecnologias visando à redução de custos, são projetos que envolvem riscos em montantes expressivos.

É público e notório que a Petrobrás tem se distinguido pela exploração de petróleo em águas profundas. A construção de plataformas off-shore de exploração de petróleo envolve bilhões de dólares empregados em novas plataformas de exploração, construídas tanto sob o regime EPC como PAHA, ou uma combinação de ambos.

${ }^{85}$ Idem, p. 82. 
Hetland, finalmente, divisa os "Projetos tipo Mudança Radical" ${ }^{86}$, dando como exemplos projetos no Mar do Norte, em que se fixam objetivos de cortar custos e prazos pela metade, sem comprometimento de qualidade, com a aplicação de tecnologia totalmente nova. Nesse tipo de projeto, como o escopo contratual é certo e o objetivo é completá-lo em prazo e custo muito reduzidos, mas os procedimentos e técnicas para fazê-los ainda estão por ser criados, sem comprometimento de qualidade, estruturas contratuais tradicionais são abandonadas em favor de concursos (concursos de arquitetura, por exemplo), ou grupos de trabalho em paralelo sobre o mesmo problema. Nesses casos, o fornecedor vencedor é devidamente premiado ou tem sua atuação garantida em outros projetos.

Sem querer entrar mais a fundo na questão da complexidade, neste ponto seria importante deixar patente que se trata de noção que somente pode ser avaliada comparativamente a certo referencial, sendo questão de grau e tempo. Dessa maneira, uns contratos são mais ou menos complexos do que outros, comparativamente. Contratos também podem se tornar menos complexos ao longo do tempo, à medida que as contingências que os circundam se tornem mais conhecidas e que a experiência sobre eles se acumule. Assim, para mitigar as incertezas advindas da complexidade dos contratos de engineering é que a experiência internacional tem se socorrido dos contratos-tipo, como visto no capítulo anterior. Contratos-tipo, no caso do engineering, consolidam a experiência do tráfico negocial, servindo como referência e ponto de mitigação dos efeitos da complexidade da relação jurídica subjacente.

Note-se que a complexidade do contrato de engineering não é apenas referente a seu objeto, cuja consecução envolve várias disciplinas, como já visto, mas também é relativa à contraprestação pela execução do objeto, já que são várias as formas de alocação de riscos instrumentalizadas pelas cláusulas de determinação do preço e pagamento ${ }^{87}$ e ainda à determinação da responsabilidade do engenheiro, já que são bastante freqüentes as cláusulas de limitação ou exoneração de responsabilidade.

\footnotetext{
${ }^{86}$ Idem, p. 83.

${ }^{87}$ Como se verá no decorrer deste trabalho, contratos de engineering são sujeitos a diversas formas de determinação do preço, que variam do preço fixo ao contrato por administração, em que a remuneração do engenheiro se atrela ao custo dos materiais e outro serviços empregados na obra. Da mesma forma, quanto à forma de pagamento, esses contratos podem prever o pagamento atrelado ao progresso físico da obra, ou parcelas fixas ou variáveis, retenções em garantia, esquemas diversos para cada parcela da obra etc.
} 
Como já se disse, as notas características do engineering acima citadas (a figura do empresário-engenheiro como parte integrante do contrato e sua complexidade) são antes complementares, já que a complexidade do contrato e da realidade técnico-econômica que lhe é subjacente demanda a condução da consecução do objeto por ente tecnicamente qualificado e a organização sob a forma empresarial da multiplicidade de fatores incidentes sobre a execução da obra.

\subsubsection{Risco}

Complexidade e risco são noções intimamente $\operatorname{associadas~}^{88}$, como visto acima, a ponto de ser praticamente impossível a dissociação entre uma noção e outra. A engenharia basicamente lida com essas noções ${ }^{89} \mathrm{em}$ seu dia-a-dia. As atribuições do engenheiro, arquiteto e engenheiro-agrônom ${ }^{90}$ referem-se à realização de empreendimentos, ou, mais genérica e abstratamente, à formulação e construção de sistemas, considerados estes como um conjunto de componentes interligados em vista de um fim. Essa

\footnotetext{
${ }^{88}$ Sobre a relação entre complexidade e risco, vide Luhmann, N.; Social Systems, pp. 24 e 25.

${ }^{89}$ Wang, J. X e Roush, M.; Risk Engineering - Dealing with System Complexity and Engineering Dynamics, in What Every Engineer Should Know about Risk Engineering and Management, Nova York, Marcel Dekker, 2000, p. 12 :

Engineers deal daily with risk, both professionally in providing advice to their clients, and commercially in operating their own business, whether selfemployed or as an employee. The engineering risks are increasing as projects become more complex. In response to this, risks need to be identified, evaluated and managed in a formal system of control rather than the informal systems which have existed in the past.. The primary responsibility of an engineer is to make technical decisions. Often, such decisions have to be based on incomplete information; thus, the outcomes of engineering decisions invariably involve uncertainty. In these circumstances, risk in inherent in the engineering decisionmaking process.
}

${ }^{90}$ Vide artigo $1^{\mathrm{o}}$ da Lei $\mathrm{n}^{\mathrm{o}} 5.194$, de 24.12.1966:

Art $.1^{\circ}$ As profissões de engenheiro, arquiteto e engenheiro-agrônomo são caracterizadas pelas realizações de interêsse social e humano que importem na realização dos seguintes empreendimentos:

a) aproveitamento e utilização de recursos naturais;

b) meios de locomoção e comunicações;

c) edificações, serviços e equipamentos urbanos, rurais e regionais, nos seus aspectos técnicos e artísticos;

d) instalações e meios de acesso a costas, cursos e massas de água e extensões terrestres;

e) desenvolvimento industrial e agropecuário. 
multiplicidade de elementos componentes do sistema traz em si riscos, também das mais diversas e numerosas espécies ${ }^{91}$, em vista das contingências a que cada um deles está sujeito.

\subsubsection{O decurso do tempo}

Por outro lado, todo contrato que não seja de execução instantânea implica assunção de riscos, por menores que sejam. Esses riscos são conexos ao próprio decurso do tempo que, nas relações humanas - e mesmo naturais - trazem a incerteza, ou a contingência, uma vez que o decurso do tempo pressupõe a ocorrência de uma sucessão de eventos que podem ou não interferir no cumprimento de dada promessa.

Quando as partes celebram contratos de execução diferida ou de longa duração, antevêem certa sucessão de eventos, certa continuidade que medeia a celebração do contrato e sua execução, mas, como eventos futuros, são contingentes, porque podem ou não ocorrer.

\footnotetext{
Nesse sentido Aristóteles dizia que ${ }^{92}$ :

No que toca a coisas presentes ou passadas, as proposições, sejam afirmativas ou negativas, são necessariamente verdadeiras ou falsas. [...] Quando, entretanto, lidamos com proposições cujos sujeitos são particulares enquanto seus predicados se referem ao futuro e não ao presente ou ao passado, percebemos que a situação se altera completamente. [...] Estamos cientes, com base em nossa experiência pessoal, que eventos futuros podem depender das deliberações e ações e que, nos expressando de um modo geral, as coisas que não estão ininterruptamente em ato exibem uma potência, isto é, 'a possibilidade de ser e de não ser'.[...] Constatamos que alguns casos, ademais, ao menos no que tange à maioria e ao mais comum, apresentam tendência numa certa direção, o que não os impede, não obstante, de poderem, ocasionalmente, surgir na outra direção ou direção mais esporádica.
}

Ainda que somente consigamos afirmar sobre o que ocorreu no passado e o que ocorre no presente, projetamos o que ocorrerá no futuro com base em

\footnotetext{
${ }^{91}$ Para vasta taxonomia dos riscos encontráveis nos contratos de construção, vide Bruner e O'Connor; in Bruner \& O'Connor on Construction Law, West Group, 2002, vol. 2, capítulo 7, pp. 651-1070 e 2006 Cumulative Supplement, pp.27-154. Os Autores descrevem inúmeros riscos relacionados a: projeto, formação de contrato, formas societárias de limitação de responsabilidade, terreno e solo, suprimento de recursos, meio-ambiente, tecnologia empregada, comunicações, propriedade intelectual, financeiros, força maior, políticos e cambiais etc.
}

92 Aristóteles, Da interpretação, trad. Bini, E. São Paulo, Edipro $1^{\text {a }}$ ed; , 2005, pp. 89-93.. 
nossa experiência passada ou presente. Ao formularmos proposições contratuais voltadas ao futuro, pressupomos, sob o ponto de vista lógico, que certos eventos efetivamente ocorrerão, mas o fazemos com base na percepção do passado ou do presente ${ }^{93}$, sem que possamos nos assegurar que o que imaginamos ocorrer no futuro de fato ocorrerá.

A partir dessa incerteza sobre o que ocorrerá no futuro da execução contratual, é possível, modernamente, que se atribuam, matematicamente, probabilidades para o desfecho de certos eventos relacionados ao contrato cuja execução se protrai em direção ao futuro. Por mais certa que seja a execução do contrato, por mais rudimentares as habilidades humanas envolvidas em sua execução, sempre existirá certa chance de sucesso (afirmação da proposição contratual) ou de fracasso (negação da proposição contratual) na execução contratual.

Contratos de engineering são evidentemente de longa duração demandam o decurso de certo tempo para sua execução - não porque o dono da obra somente dela fará uso dentro de certo período, mas porque a seqüência de eventos necessária à conclusão da obra demanda, aqui sim, tempo. Por mais que as técnicas modernas de fast track engineering ou concurrent engineering ${ }^{94}$ procurem reduzir o período necessário para conclusão de certa obra, ainda assim é necessária seqüência mínima de atos concatenados para o alcance da conclusão. Essa seqüência de eventos planejados pelo engenheiro não é infensa a outros eventos e outras seqüências de eventos que, mesmo externas à execução da obra, sobre ela influem. Ocorrências climáticas são típicos exemplos de eventos externos à obra, mas sobre ela influentes.

Da mesma forma, em qualquer contrato que não seja de execução instantânea, eventos paralelos continuamente influenciam a execução contratual. No entanto, no caso do engineering ou da empreitada, o decurso de tempo entre celebração e

\footnotetext{
${ }^{93}$ Como diz Macneil: "A transaction projecting exchange into the future is - both in party purpose and in traditional contract theory - an effort to preserve over a period of time all the perception of discreteness that the conscious mind permits.". Macneil, I. "The Many Futures of Contracts", Southern California Law Review, (1974), vol. 47, p. 755.

${ }^{94}$ Concurrent engineering ou engenharia concorrente refere-se a técnicas de projeto e engenharia que procuram a economia de tempo com a sobreposição e execução em paralelo, ou concorrente, de processos, por oposição à sua execução seqüencial, procurando integrar etapas de projeto e execução entre si. Vide Bogus, S; Molenaar, K. e Diekmann; Concurrent Engineering Approach to Reducing Design Delivery Time; Journal of Construction, Engineering and Management, v. 131, (2005) pp. 1179 e 1185.
} 
conclusão da execução é de sua essência, uma vez que a compra e venda, por oposição, amolda-se à execução instantânea. Ocorre que o decurso de tempo aumenta a probabilidade de que eventos externos à execução do contrato de longa duração exerçam influência sobre o resultado final. Mas uma vez, recorrendo ao exemplo quase folclórico de intempéries interferindo na execução da obra, quanto mais longa é a execução, maior a probabilidade da superveniência de chuvas ou outros fenômenos climáticos, devido à mudança das estações.

Existe, assim, no contrato de engineering, não só a constatação do risco de execução da obra em si, a ela intrínseco, como os causados por vicissitudes relacionadas ao projeto, à execução da obra, ou aos materiais empregados, mas riscos que decorrem da seqüência de eventos externos ao projeto e obra que necessariamente ocorrem durante todo o iter de execução contratual. A ocorrência desses eventos internos e externos, dada a falibilidade das ações do homem, que não consegue tudo prever e contra tudo se proteger, necessariamente produz risco ${ }^{95}$ - que se procura mensurar, instrumentalmente, pela teoria das probabilidades.

Dessa forma, é economicamente correto dizer que todo contrato que não seja de execução instantânea necessariamente traz consigo um risco de não ser cumprido, pelos mais variados motivos que se possa imaginar. Não por outra razão, o Código Civil prevê disposições como a do art. 393 e seu parágrafo único, sobre a ocorrência de eventos de caso fortuito ou da força maior, exonerando o devedor da responsabilidade pelos prejuízos deles advindos. Por mais que a tradição jurídica tenha qualificado a incidência dessa norma, fica patente que o ordenamento expressamente admite que a possibilidade de prever o futuro é limitada e que as proposições contratuais podem ser negadas com a intercessão de eventos de outra ordem.

Nos contratos de produção, como a empreitada, o engineering ou mesmo os contratos de produção agrária, existe incerteza em variado grau não somente

\footnotetext{
95 Já dizia o clássico Knight, em seu livro originalmente publicado em 1921(Knight, F.; Risk, Uncertainty and Profit, p. 199_: by knowing something about the future; while the problem of life, or of conduct at least, arise from the fact that we know so little. This is as true of business as of other spheres of activity.
} 
sobre o custo de execução, o que afeta o empreiteiro ou produtor, como também sobre a utilidade que o bem produzido terá para o dono da obra ou comprador à época da entrega.

Pensando-se em como um projeto pode se inviabilizar sob a perspectiva do dono da obra, imaginemos, em exemplo rudimentar, que o planejamento de construção de uma usina de energia elétrica haja tomado como pressuposto que as taxas de juros básicos e de longo prazo de certo país se mantivessem em patamar histórico de, digamos, 5\% ao ano. Pressupondo ainda a existência de um mercado competitivo de energia, o preço médio de mercado da energia deveria ser tal que, no longo prazo, a taxa de retorno esperada da usina fosse maior que 5\% ao ano - caso contrário, o dono da obra preferiria ter investido seu capital em títulos públicos, teoricamente de baixíssimo risco, que pagassem juros de 5\% ao ano. Intuitiva e simplificadamente e sempre por hipótese, sendo o preço médio de longo prazo da energia historicamente fixo, ou relativamente fixo, aumentos do preço da obra ou demora na conclusão da obra, ou mesmo decréscimos do preço da energia impactariam significativamente a taxa de retorno esperada do empreendimento.

\title{
2.3.3.2 Controlabilidade e prevenção
}

Como não se pode falar em contrato de engineering sem se falar em riscos, é importante ter em perspectiva que, como dizem Levitt et al..$^{96}$ a grosso modo, existem dois tipos de riscos: os controláveis e os incontroláveis:

\begin{abstract}
There are two types of risks - controllable and uncontrollable. Uncontrollable risks are random variables such as material price escalation, weather, and unpredictable changes in underground conditions or properties. Controllable risks reflect variations in human performance, such as number or design omissions, low worker productivity, and material wastage. Some categories or risk can be thought or as a combination of controllable and uncontrollable risks, such as worker accidents. However, if the magnitude or the cost implications of risk can be influenced by any of the participants, that risk is considered to be controllable.
\end{abstract}

A classificação dicotômica acima, ainda que não conclusiva, como se verá, é ilustrativa e corre em paralelo com as definições de caso fortuito e força maior (riscos incontroláveis) e com a de imperícia (riscos controláveis). O devedor, como regra

${ }^{96}$ Levitt, R.; Ashley, D. Logcher, R; Allocating Risk and Incentive in Construction; Journal of the Construction Division (ASCE), vol. 106, nº 3, setembro 1980, p. 299. 
geral, não estaria obrigado a suportar os efeitos da concretização de riscos incontroláveis, mas, no entanto, estaria obrigado a responder pelos efeitos da materialização de riscos controláveis.

A dicotomia entre riscos controláveis e riscos incontroláveis, sob o ponto de vista físico, no entanto, não segue em estrita conexão com a explicitação econômica - também dicotômica - provida por Richard Posner ${ }^{97}$. Para Posner, deve-se distinguir entre as noções de prevenção e seguro como métodos de redução de perdas causadas pela implementação de riscos. Segundo o autor, "perdas que possam ser evitadas por uma despesa menor que a perda esperada são suscetíveis de prevenção" ${ }^{98}$. Em outras palavras, se a probabilidade da perda multiplicada pela magnitude dessa mesma perda resulta em valor superior ao custo da prevenção, trata-se de risco suscetível de prevenção.

Dessa forma, embora existam riscos fisicamente incontroláveis (por exemplo, os raios), do ponto de vista econômico, esses riscos podem ser suscetíveis de prevenção - por exemplo, pela contratação de seguros, ou colocação de pára-raios. A questão, do ponto de vista contratual, desloca-se da incalculabilidade ou irreversibilidade dos fenômenos naturais, que podem eximir o devedor do cumprimento da obrigação, para a identificação da parte que possa arcar com o risco ao menor custo possível ${ }^{99}$, ou seja, desloca-se para a alocação eficiente de riscos.

Como arremate desta consideração a respeito da incidência do risco sobre a relação contrato do contrato de engineering, vale trazer a citação de Mario Bessone que, logo no início de sua sempre citada obra "Adempimento e Rischio Contrattuale" diz"100.

\footnotetext{
${ }^{97}$ Posner, R., Economic Analysis of Law, Aspen Publishers, New York, 6 a ed., 2003, pp. 105 e ss.

${ }^{98}$ Posner, R.,; op. cit., p. 105.

${ }^{99}$ Para Posner, uma das cinco funções do direito dos contratos é a "alocação do risco a seu portador (ou assuntor) superior - superior risk bearer". As demais são: a prevenção do oportunismo, a interpolação (ou provisão) de termos eficientes; a prevenção de erros evitáveis no processo de contratação; e a reduçãod os custos de resolução das disputas contratuais, Idem, p. 98.

${ }^{100}$ Bessone, M. Adempimento e Rischio Contrattuale. Milão, Giuffrè, $2^{\mathrm{a}}$ reimpressão inalterada, 1998, pp. 12:
}

La conclusione di un contratto espone al rischio di ogni iniziativa economica. Proposta ed accettazione muovono da una valutazione delle circostanze e da ragionevoli previsioni sull'esito dell'affare. Ma le circostanze evolvono incessantemente e un evento che ne turba $i$ presupposti può sempre pregiudicare il successo dell'iniziativa. Le circostanze che possono sconvolgere 
A conclusão de um contrato expõe ao risco de cada iniciativa econômica. Proposta e aceitação movem-se de uma valoração das circunstâncias e de razoáveis previsões sobre o êxito do negócio. Mas as circunstâncias evoluem incessantemente e um evento que lhe turba os pressupostos pode sempre prejudicar o sucesso da iniciativa. As circunstâncias que podem perturbar a economia de um contrato são numerosas e - em larga medida esse risco não pode ser evitado: contudo, a lei predispõe técnicas para circunscrever a área e outras o elabora a autonomia privada (tradução nossa).

Nesse sentido, vale a pena transcrever trecho de autoria de Kendrick, em obra especializada sobre identificação e gerenciamento de $\operatorname{riscos}{ }^{101}$ :

Every project has risk. There is always at least some level of uncertainty in a project's outcome, no matter what the Microsoft Gantt chart on the wall seems to imply. High-tech projects are particularly risky, for a number of reasons. First, technical projects have high variation. While there are invariably aspects of a project that resemble earlier work, every project has unique aspects and has objectives that differ from previous work in some material way. Because the environment of technical projects evolves very quickly, there can be much larger differences from one project to the next than may be found in other types of projects. In addition, technical projects are frequently staffed "lean" and may also do their work with inadequate funding and equipment. To make matters worse, there is a pervasive expectation that, however fast the most recent project may have been, the next one should be even quicker. Technical projects chronically accept aggressive challenges to execute ever more rapidly. Risks on technical projects are significant, and their number and severity continue to grow. To successfully lead such projects, you must consistently use the best practices available.

Justamente a partir das precisas citações de Bessone e Kendrik, fica claro que o elemento de risco substancial do contrato de engineering compõe a própria operação econômica que este instrumentaliza. Esse elemento de risco, por sua vez, está em relação estreita com o elemento de complexidade dessa mesma operação econômica, demandando da empresa de engenharia contratada a habilitação correspondente que decorre de sua qualificação para fazer face a tais vicissitudes.

l'economia di un contratto sono numerose e - in larga misura - questo rischio non può essere evitato: tuttavia la legge predispone tecniche per circoscriverne l'are ed altre me elabora l'autonomia privata. (notas de rodapé omitidas)

${ }^{101}$ Kendrick, T.; Identifying and Managing Project Risk: Essential Tools for Failure-Proofing Your Project, New York, Amacon, 2003, pp. 1-2. 


\title{
2.4 QUALIFICAÇÃO DOS CONTRATOS DE ENGINEERING
}

\author{
Como diz Roppo ${ }^{102}$
}

A qualificação do contrato é a operação lógica com que o intérprete - frente a um contrato concreto - afirma ou nega sua reconducibilidade a um determinado tipo contratual. A sua função principal é estabelecer se ao contrato é aplicável a disciplina de algum tipo; e, se sim, de qual tipo.(tradução nossa)

Diferentemente de alguns dos entendimentos advindos da comparação com o direito italiano, não se afiguram os contratos de engineering entre nós como contratos atípicos, mas sim como contratos socialmente típicos ${ }^{103}$.

O percurso da tipificação dos contratos de engineering é clássico e segue perfeitamente a descrição evolutiva do tipo proposta por Rachel Sztajn ${ }^{104}$ :

6. Os tipos legais têm sua origem ligada ao tráfico econômico, vale dizer, aos usos e costumes, como formas de comportamento social. No campo obrigacional a atividade comercial é pródiga na criação de usos e costumes. A prática da inserção de cláusulas padronizadas nos contratos entre comerciantes, transformadas em cláusulas de uso, originando os usos comerciais, ganha conotação de comportamentos concretos e reiterados, padronizados, espraiando-se para outras praças e situações. Se ao final de certo tempo os usos e costumes ainda permanecem válidos, mantendo sua importância, terminam por refletir um "tipo social". Os contratos socialmente

${ }^{102}$ Roppo, V., Il Contratto, cit., p. 429: “

La qualificazione del contratto è l'operazione logica con cui l'interprete - di fronte a un concreto contratto - ne afferma o nega la reconducibilità a un determinato tipo contrattuale. La sua funzione principale è stabilire se al contratto sia applicabile la disciplina de qualche tipo; e se sì, di quale tipo.

103 Aqui, cabe recorrer ao que diz Rachel Sztajn sobre a tipicidade contratual (Sztajn, R. Contrato de Sociedade e Formas Societárias, São Paulo, Saraiva,1989, p. 14.):

Contratos típicos são os contratos nominados, aqueles que têm nomen juris, têm individualidade e regras próprias, típicas. Contratos atípicos ou inominados são os que não contam com essa disciplina específica e se subordinam às disposições gerais aplicáveis ao negócio visado, razão por que, na esteira da doutrina alemã, denominam-se contratos atípicos os inominados e típicos os nominados. Indicase com o vocábulo 'típico' a existência de normas que delimitam, marcam as características da operação econômica. O ordenamento jurídico estatui individualmente quanto aos contratos típicos, por representarem a regulamentação de interesses habituais em certa coletividade, satisfazendo exigências econômicas fundamentais desse grupo humano.

${ }^{104}$ Sztajn, R, op. cit., pp. 11-12 (notas de rodapé omitidas) 
típicos, nascidos da prática negocial, são apreendidos pelo ordenamento jurídico na sua caracterização, passando a integrá-lo como tipo legal.

Esse contrato socialmente típico é, então, descrito pelo legislador, construindo-se definição de tipo contenutístico, porém semelhante à definição legal de conceito. $\mathrm{O}$ confronto de cada contrato concreto com o modelo legal se faz, tratando-se de contrato típico, diretamente com a definição legal; se contrato socialmente típico, o confronto se faz em dois níveis: primeiro o do caso concreto com o contrato socialmente típico e, a seguir, o deste com um dos modelos legais.

A evolução dos contratos de engineering corresponde ao seu reconhecimento social, a partir da aplicação do modelo típico da empreitada, mas, em processo de diferenciação, passa a ter pressuposto específico, qual seja, a presença da empresa de engenharia como parte no contrato, instrumentalizando operação econômica que possui notas de complexidade e grau de risco que não são necessariamente encontrados no tipo legal empreitada.

Com efeito, a empreitada, como prevista no Código Civil, não requer, necessariamente, a presença do engenheiro ou da empresa de engenharia como parte prestadora dos serviços. Por seu turno, a Lei $\mathrm{n}^{\circ}$. 5.194, de 24.12.1966, em pleno vigor, que regula o exercício das profissões de Engenheiro, Arquiteto e Engenheiro-Agrônomo, em seu artigo 15, sanciona de nulidade "os contratos referentes a qualquer ramo da engenharia, arquitetura ou da agronomia, inclusive a elaboração de projeto, direção ou execução de obras, quando firmados por entidade pública ou particular com pessoa física ou jurídica não legalmente habilitada a praticar a atividade nos têrmos desta lei.”. Ou seja, enquanto a empreitada não requer habilitação especial do empreiteiro, a operação econômica instrumentalizada pelos contratos de engineering demanda conhecimentos inerentes à engenharia, arquitetura ou agronomia, observando-se, assim, uma primeira nota diferenciadora destes em relação à empreitada.

Assim, no Brasil, a figura do engenheiro ou da empresa de engenharia em um dos pólos dos contratos de engineering é elevada à categoria de pressuposto típico ${ }^{105}$. Resta elaborar a tipificação do contrato de engenharia a partir da dicotomia estrutura e função ${ }^{106}$.

\footnotetext{
${ }^{105}$ Uma vez mais, recorre-se a Rachel Sztajn, que, citando Calmon de Passos, ensina (Sztajn, R., op. cit., p.
} 16):

Esclarece Calmon de Passos que o tipo, na sua significação jurídica, é mais que a hipótese de fato prevista na norma. Seu estudo envolve o de: a) seus 
Seguindo a corrente que considera os contratos de engineering atípicos, Cavallo Borgia qualifica-os da seguinte maneira:

O contrato de engineering é um contrato atípico ou inominado, de empresa, oneroso, com o qual o engineer assume frente ao comitente a obrigação projetística, financeiro-organizativa e também executiva de um opus articulado e complexo, bem como os riscos conseqüentes, mediante contraprestação em dinheiro. O engineering é, também, um contrato atípico "em senso próprio", cuja causa não é o resultado da fusão de elementos causais diversos, mas é única e autônoma, enquanto plúrimas são as prestações articuladas e integradas entre si de modo a permitir a realização da causa atípica, ou seja, a troca de um opus complexo, pelo preço. ${ }^{107}$ (tradução nossa)

Do ponto de vista estrutural e considerando o ordenamento brasileiro, os contratos de engineering seguem os elementos característicos da empreitada, configurando-se como contratos sinalagmáticos, comutativos, onerosos e consensuais. Entretanto, pode-se dizer que os contratos de engineering apresentam diferenças de grau e especificidade em relação à empreitada. Nesse sentido, contratos de engineering são tipicamente de empresa e sua comutatividade difere da empreitada pelo característico da presença de álea maior ou menor em função da presença e alocação de riscos que derivam de sua complexidade, como dito acima. Assim como a empreitada, os contratos de engineering são, em sua tipicidade peculiar, geralmente simples, do ponto de vista de classificação jurídica, (por oposição aos contratos juridicamente complexos), não obstante

pressupostos (condições de existência); b) seus elementos de composição (elementos normativos propriamente descritivos); c) seus elementos de situação (elementos que situam a hipótese de fato no procedimento). Ficam à margem do tipo a vontade (final) e a causa. Ainda quando elementos constitutivos do ato, não pertencem a sua materialidade executiva.

\footnotetext{
${ }^{106}$ Em outras palavras, é necessário tratar da dicotomia posta por Bobbio entre "como o direito é feito" e "a que coisa serve" (Bobbio, N; Dalla struttura alla funzione - Nuovi studi di teoria del diritto, Milão, Edizioni di Comunità, 1977, p 63: "In parole povere, coloro che si sono dedicati alla teoria generali del diritto si sono preoccupati molto di più di sapere 'come il diritto sia fatto' che 'a che cosa serva'."

107 Cavallo Borgia, R., Il Contratto di Engineering, Pádua, Cedam,, 1992, p. 135:

Il contratto di engineering è un contratto atipico o innominato, di impresa, a titolo oneroso, con il quale l'engineer assume verso il committente l' obbligo progettuale, finanziario organizzativo e anche esecutivo di un'opus articolato e complesso ed $i$ conseguenti rischi, verso un corrispettivo in denaro. $L^{\prime}$ engineering è, altresì, un contratto atipico 'in senso proprio', la cui causa non è il risultato della fusione di elementi causali diversi, ma è unica ed autonoma, mentre plurime sono le prestazioni articolate ed integrate fra loro in modo da consentire la realizzazione della causa atipica, ovvero lo scambio di un'opus complesso, contro prezzo.
} 
seja freqüente a presença de elementos caracterizadores de outros tipos, como a locação (de equipamentos, venda e compra, ou prestação continuada de serviços, por exemplo).

Contrariamente ao entendimento acima, a doutrina, especialmente a italiana, vem tratando dos contratos engineering como juridicamente complexos, e, como definido por Alpa ${ }^{108}$, sempre com base na jurisprudência italiana, aquele que:

Resulta da combinação de distintos esquemas negociais, unitariamente considerados pelas partes, com base em causa única, que deriva da fusão dos elementos causais dos contratos que concorrem na formação da relação e dependente de um único nexo objetivo e funcional, de modo que as várias prestações, intimamente e organicamente mescladas e reciprocamente condicionadas em sua própria essência e nas suas modalidades de execução, resultem pré-ordenadas ao alcance de um único intento negocial em senso objetivo, de modo a dar vida a uma convenção unitária com individualidade autônoma.

Embora, raciocinando-se tipologicamente, os contratos de engineering sejam prevalentemente simples, a complexidade jurídica do contrato de

${ }^{108}$ Alpa, G.; "Engineering: Problemi de Qualificazione e di Distribuzione del Rischio Contrattuale”, in Nuovi Tipi Contrattuali e Tecniche di Redazione Nella Pratica Commerciale - Profili Compartitici Quaderni di Giurisprudenza Commerciale, a cura de Piero Verrucoli, n. ${ }^{\circ}$ 14, Milão, Giuffré, 1978, p.. 336 . O autor considera que os contratos complexos constituam subclassificação dos contratos atípicos. Vale ressaltar que essa consideração não é unanimemente aceita, mesmo na Itália, país que tem a causa como requisito essencial do contrato (art. 1325, n. ${ }^{\circ} 2$ do Código Civil italiano). Roppo, diferentemente, considera que os contratos complexos sejam contratos em que figuram elementos de tipos contratuais diversos (Vide Roppo, Vincenzo,, Il Contratto, cit., p. 427). Por oposição, Cavallo Borgia considera que o engineering não possa ser qualificado como contrato complexo. Para a autora:

Come è emerso dall'indagine tipologica della realtà, nel contratto in esame esiste certamente una pluralità de prestazioni, variamente articolate tra di loro in modo da poter conseguire il raggiungimento di obiettivo differenziato più o meno complessi. Ma alla pluralità di prestazioni non si può in alcun modo collegare una presunta pluralità di cause, dovendo l'eventuale presenza e combinazione di diversi elementi causali essere autonomamente verificata. (Cavallo Borgia, Rossella, op. cit., p. 126).

A posição de Cavallo Borgia funda-se na inexistência de causa plúrima no engineering e na consideração de que a classificação desse contrato como complexo poderia frustrar a potencialidade evolutiva de um modelo contratual que, em sua essência, é dinâmico e dúctil (op. cit. p. 128). Tendo em vista que o tratamento do contrato complexo se determina com base nos critérios de combinação ou absorção (vide Roppo, Vincenzo, op. cit. p. 428), Cavallo Borgia considera que a submissão do engineering aos esquemas contratuais preexistentes da empreitada ou da prestação de serviços tolhe a "esigenza di elasticità connaturata ad un contratto sottoposto ad una continua revisione critica provocata dalla rapidità con cui mutano gli elementi di riferimento." (op. cit. p. 128). Também na Itália, e mais recentemente, parece tomar força a corrente que considera os contratos de engineering sujeitos à disciplina da empreitada. Nesse sentido, vide Marinelli, F.; Engineering; in I Nuovi Contratti Nella Prassi Civile e Commerciale, vol XIII - Strutture industriale e tecnologiche; Turim, UTET, 2004, p.p. 28-29 No Brasil, como visto acima, parece ser mais difícil a subtração dos elementos da empreitada na qualificação do engineering. 
engineering só pode derivar da constatação de que, como diz De Nova ${ }^{109}$, com o termo engineering se indique mais um gênero que um tipo de contrato, já que os serviços ofertados pela empresa de engenharia podem variar entre uma gama que vai da consultoria à elaboração de projetos, do gerenciamento de construções ao turnkey, ou contratos de empreitada integral, da operação à manutenção, daí porque, como nota o mesmo De Nova, Alpa ${ }^{110}$ prefira se referir a "contratos de engineering”, ao sublinhar sua pluralidade.

É na referência à obra que se encontra a pedra de toque da empreitada, que a distingue da prestação de serviços. Nesse ponto, vale sempre recordar Pontes de Miranda ${ }^{111}$ :

1.PRECISÕES - A obra pode consistir em criar, modificar, aumentar, diminuir, ou destruir algum bem, ou parte do bem. Para obter-se o resultado que se quer, ou se exigem serviços, que se prestem como serviços, ou se exige a obra, de modo que os serviços apenas ocorrem como meios para o resultado que se quer. De modo que a prestação é de obra, e não de serviços.

A empreitada pode ser com ou sem o fornecimento dos materiais pelo empreiteiro. Não importa se só alguns materiais são do empreiteiro, nem se o empreiteiro é quem os compra e o empreitante paga.

A obra pode consistir em criar o bem que se quer, ou em destruí-lo, ou em modificá-lo. Há, por exemplo, respectivamente, a empreitada para edificar a casa, ou para tirar o cômoro ou a mata e jogar no mar, ou no rio, ou queimar, como há a empreitada para fazer mais um andar no prédio, ou apenas para o pintar. A prestação de serviços não é devida como serviços, mas pelo resultado. Os serviços, na empreitada, apenas são meios para se obter aquilo que se prometeu. De modo que o que se prometeu e se deve é o resultado, e não os serviços.

Por isso mesmo, em princípio, não se exige que o empreiteiro faça, pessoalmente, a obra. Em todo o caso, há obras para as quais o que mais importa é que seja feita pela pessoa que a empreitou. É o que se passa com o edifício que se deseja construído pelo arquiteto-construtor B, ou pelo construtor $\mathrm{C}$, que se reputa $\mathrm{o}$ mais apto à construção que o arquiteto $\mathrm{A}$

${ }^{109}$ De Nova, Giorgio, “Nuovi Contratti”, UTET, Turim, 2 Ed. 1994, p. 69

${ }^{110}$ Alpa, G. e Fusaro, A., I contratti di engineering, in "Trattato di Diritto Privato", direto da Pietro Rescigno, vol. 11 , tomo $3^{\circ}, 2^{\mathrm{a}}$ ed., UTET, Torino 2000 , p. 173 - vale transcrever o trecho que trata do assunto:

È pero opinione corrente che nella prassi negoziale degli ultimi anni esso abbia mutato la sua fisionomia originaria, e si sia sdoppiato in due sottospecie: vi è infatti un contratto di engineering che corre sotto il nome di 'consulting engineering', ed un contratto di engineering che viene qualificato invece come 'commercial engineering'. Anche queste denominazioni non individuano con precisione un 'tipo contrattuale, ma piuttosto una sottocategoria, all'interno della quale $i$ contratti di engineering assumono $i$ contenuti più vari. Solo esigenze di semplificazione possono indurre a ritenere, per convenzione, che si possa parlare di contratto di engineering; mentre una più realistica valutazione dell'esperienza suggerisce di mantenere caratteri di pluralità a queste operazioni economiche, definendole piuttosto come contratti di engineering.

${ }^{111}$ Pontes de Miranda, Tratado de Direito Privado, Tomo XLIV, Revista dos Tribunais, São Paulo, 1984, $3^{\mathrm{a}}$ ed., $2^{\mathrm{a}}$ reimp., pp. 375-376. 
planejou. Tratando-se de obras de arte, ou de obras literárias, inclusive de traduções, o nível do empreiteiro é da maior relevância, por vêzes pelo fato de ser de valor a nominação.

Doutrinariamente, portanto, o tipo empreitada, tem como ponto central a obra, como um resultado referido à criação, modificação, aumento, diminuição, ou destruição de algum bem, ou parte do bem, que se alcança pela prestação de serviços, pela incidência do trabalho humano sobre esse bem ${ }^{112}$. Em outras palavras, os contratos de engineering estão em função da execução de obras que, embora sejam de grande porte e complexas, não deixam de servir à criação, modificação, aumento, diminuição, ou destruição de algum bem, com dito por Pontes de Miranda, acima. Portanto, o tipo contratual da empreitada abrange o do engineering.

Assim, o contrato de empreitada, legalmente típico, não deixa, em regra geral, no ordenamento vigente, de alcançar os contratos de engineering, visto que, embora os artigos 610 e seguintes do Código Civil não tragam a definição da empreitada, a referência a "edifícios ou outras construções consideráveis", constante do artigo $618^{113}$, e "projeto", constante dos artigos 610, $\S 2^{\circ}, 621$ e 622 dão, ao mesmo tempo, a amplitude e a referência à engenharia que confere suficiente abrangência ao contrato de empreitada em relação ao contrato de engineering, em termos de conteúdo. Por outro lado, se a empreitada não requer, necessariamente, a presença do engenheiro ou da empresa de engenharia como parte prestadora dos serviços, a Lei $n^{\circ} .5 .194$, de 24.12.1966, que regula

${ }^{112}$ Pontes de Miranda seguiu a linha alemã na definição do contrato de empreitada, em que se lê:

$\S 631$ Vertragstypische Pflichten beim Werkvertrag

(1) Durch den Werkvertrag wird der Unternehmer zur Herstellung des versprochenen Werkes, der Besteller zur Entrichtung der vereinbarten Vergütung verpflichtet.

(2) Gegenstand des Werkvertrags kann sowohl die Herstellung oder Veränderung einer Sache als auch ein anderer durch Arbeit oder Dienstleistung herbeizuführender Erfolg sein.

Ou, em tradução para o italiano:

\$ 631 Obblighi contrattuali tipici del contratto d'opera

(1) Mediante il contratto d'opera, l'imprenditore si obbliga a realizzare l'opera promessa, e il committente a versare il corrispettivo pattuito.

(2) Oggetto del contratto d'opera può essere sia la produzione o la modifica di una cosa, sia un altro risultato da ottenere con il lavoro o con la prestazione di servizio.

In Patti, S (coord.), Codice Civile Tedesco, , Milão, Giuffrè 2005, pp. 451-452.

${ }^{113}$ Que sucede o antigo artigo 1.245 do Código revogado. 
o exercício das profissões de Engenheiro, Arquiteto e Engenheiro-Agrônomo, em seu artigo 15, a sanciona de nulidade o contrato de engineering em que o empreiteiro não tenha a habilitação requerida.

Hipóteses há, evidentemente, de contratos que envolvam a disciplina de engenharia e não possam ser considerados empreitadas, como os contratos de prestação de serviços continuados de engenharia, entre eles a manutenção ou operação de bens que exijam o conhecimento técnico especializado. Mas, se nem toda empreitada é contrato de engenharia (por faltar a habilitação do empreiteiro como engenheiro ou arquiteto, por exemplo) e nem todo contrato de engenharia é empreitada, pode-se dizer que os contratos de engineering estão situados numa área de intersecção entre o contrato cuja celebração, como uma das partes, é privativa do engenheiro e a empreitada.

De fato, os contratos de engineering, em sua singularidade, são sobrejacentes a operações econômicas de grande complexidade, já que geralmente relacionam-se à execução de obras de grandes dimensões e de valor substancial ${ }^{114}$. Como afirma Cavallo Borgia, ${ }^{115}$, a sempre maior especialização das prestações requeridas, a crescente interdisciplinaridade que dela decorre, a necessidade de tecnologia constantemente evoluída, provocam ininterrupta e progressiva variação do conteúdo contratual sempre mais articulado e integrado. Na esteira desse raciocínio, Cavallo Borgia vê, nos diversos subtipos do contrato de engineering, características que os perpassam e que permitem seu estudo a partir da análise dos usos e costumes empresariais. Diz a autora $^{116}$ :

\footnotetext{
${ }^{114}$ Alpa, G. e Fusaro, A.; op. cit., p. 173.

${ }^{115}$ Cavallo Borgia, R., op. cit., p. 29.

${ }^{116}$ Cavallo Borgia, R., op. cit., p. 36.:
}

Ed invero nel panorama tipologico che emerge dall'analisi delle particolari strutture contrattuali sono individuabili talune costanti, quali prevalentemente il riferimento alla progettazione elo alla realizzazione di opere qualificate dalla loro rilevante dimensione e dalla notevole entità dell'investimento, che esigono una pluralità e complessità di competenze tecnicoprofessionali - imprenditoriali. Si e in sostanza di fronte ad un'attività in cui elemento condizionante necessario e l'interdipendenza ed il coordinamento tra aspetti progettuali di ogni tipo tra loro, tra fase progettuale e quella più propriamente attinente alla esecuzione del progetto, tra il momento della realizzazione e quello della utilizzazione dell' opera.

Parallelamente nel contratto posto in essere e sempre presente, o quantomeno 
E, em verdade, no panorama tipológico que emerge da análise das particulares estruturas contratuais, são individualizáveis algumas constantes, como a prevalente referência a projeto e/ou a realização de obra qualificada por sua relevante dimensão, ou das entidades de investimento relevantes, que exigem uma pluralidade e complexidade de competências técnicas, profissionais e empresariais.

Está-se, em substância, frente a uma atividade cujo elemento condicionante necessário é a interdependência e a coordenação entre aspectos projetísticos de cada tipo entre si, entre a fase de projeto e aquela mais propriamente atinente à execução do projeto, entre o momento de realização e aquele da utilização da obra.

Paralelamente, no contrato em questão é sempre presente, ou ao menos pressuposta, a moderação orgânica entre elementos antecedentes e sucessivos à atuação da iniciativa, todos dinamicamente projetados em vista do resultado final. Em outros termos, em exame menos formal, não obstante a amplitude e a variedade dos setores em cuja atividade é desenvolvida e a correlativa analiticidade das disposições convencionais das obrigações específicas das partes, o contrato de engineering apresenta, por força das particulares implicações dos objetivos concretos perseguidos, uma fisionomia própria constante. (tradução nossa)

Assim sendo, a evolução histórica do tipo contratual da empreitada levou os contratos de engineering à tipificação, não pela lei, mas, socialmente, por contratos-tipo, ou formulários, de aceitação internacional, que imprimem um tratamento mais amplo e detalhado a esses contratos, como visto no Capítulo 2, acima. Nesse sentido, Maria Costanza observa que a coexistência de condições gerais de contrato instrumentalizadas, no caso do engineering, por contratos-tipo - com uma dada disciplina normativa aplicável significa que "as condições gerais de contrato têm conteúdo que, ao menos em regra, diferencia-se daquele da norma de lei e por isso exprime qualquer coisa de diverso ou que lhe [à norma de lei] falta. ${ }^{117, " ~(t r a d u c ̧ a ̃ o ~ n o s s a) . ~}$

presupposto, un organico contemperamento tra elementi antecedenti e successivi all'attuazione dell'iniziativa, tutti dinamicamente proiettati verso il risultato finale. In altri termini, ad un esame meno formale, nonostante l' ampiezza e Ia varietà dei settori in cui l' attività viene prestata e Ia correlativa analiticità della previsione convenzionale degli specifici obblighi delle parti, il contratto di engineering presenta, in forza dei particolari connotati degli obiettivi concreti perseguiti, una sua fisionomia costante.

${ }^{117}$ Costanza, M; Il Contratto Atípico; Milão, Giuffrè, 1981, pp. 273 e 274. Vale transcrever o parágrafo que contém a citação acima, por esclarecedor:

Da questo punto di vista, anzi, si pone un interrogativo: che significato può avere l'impiego di condizioni generali di contratto quando sussiste già una normativa positiva? La risposta non e difficile: le condizioni generali di contratto hanno un contenuto che, almeno di regola, si differenzia da quello della norma di legge e perciò esprime qualcosa di diverso o che là manca. Le condizioni generali di contratto ovvierebbero ciò̀ alle carenze della legge sia in ordine ai contratti nominati che ai contratti atipici. Le condizioni generali di contratto in molti casi hanno difatti contribuito alla nascita e alla diffusione di strumenti negoziali privi di una disciplina positiva o hanno determinato il distacco di una 
A complexidade apontada, note-se ademais, também cria dificuldades na aplicação de distinções tradicionalmente utilizadas pela dogmática para resolução de problemas de qualificação, como a distinção entre obrigações de meio e resultado $^{118}$, dificuldades essas que não escaparam à doutrina e jurisprudência italianas, tendo a primeira observado que "o reclamo à distinção entre obrigações de meio e resultado no julgamento da licitude do contrato de engineering é considerada inoportuna pela doutrina dominante em virtude da própria insegurança teórica da distinção"119.

Com efeito, ao contrário do Código Civil italiano, que traz a noção de empreitada ${ }^{120}$, o código civil brasileiro não delineia contornos precisos para esse tipo contratual, definindo somente o objeto de sua prestação, qual seja, a entrega da obra, com contribuição de serviços ou destes e materiais. Usando-se um axioma empregado por Roppo $^{121}$, "quanto mais baixa é a definição do tipo, tanto maior sua elasticidade" (tradução

figura contrattuale dalla fattispecie codificata. Se a questa circostanza si aggiunge che, per il loro carattere istituzionale, esse sono destinate ad operare in un numero vastissimo di rapporti, appare evidente che il risultato finale dell'impiego di questa tecnica contrattuale e una tipizzazione del contenuto di una data categoria di contratti.

\footnotetext{
${ }^{118}$ Vide Comparato, Fabio K., Obrigações de Meios, de Resultado e de Garantia, in Ensaios e Pareceres de Direito Empresarial, Forense, Rio de Janeiro, 1978, p. 539.

${ }^{119}$ Sicchiero, Gianluca; L'Engineering, La Joint Venture, I Contratti di Informática, I Contratti Atipici di Garanzia, Turim, UTET, 1991, p. 37: “
}

Talora la giurisprudenza muta il proprio orientamento, dimostrando in sostanza di fare proprie le ragioni dell'osservazione per cui 'il richiamo alla distinzione tra obbligazione di mezzi e di risultato nel giudicare della liceità del contratto di engineering è considerato inopportuno dalla dottrina dominante proprio in virtù della stessa insicurezza teorica della distinzione (m. Rescigno, Guida ragionata alla giurisprudenza in tema di engineering, cit 596, nota 38). La Corte d'appello di Milano (22 aprile 1983, cit.), in un'ipotesi in cui la società di engineering aveva assunto 'la responsabilità di coordinare i servizi inerenti la progettazione e la realizzazione del porto de Lavagna', ritiene infatti che si tratti de contratto caratterizzato certamente da 'obbligazione di attività e non di risultato, pur se tali obblighi 'scolpiscono il tratto caratteristico di quella particolare articolazione, del contratto d'appalto di servizi', che costituisce appunto l'engineering.

${ }^{120}$ Art. 1655: "L'appalto è il contratto col quale una parte assume, con organizzazione dei mezzi necessari e con gestione a proprio rischio, il compimento di un'opera o di un servizio verso un corrispettivo in denaro" in Il Codice Civile Illustrato, Piacenza, Casa Editrice La Tribuna, 2006, organização Maggese, F. e Pepe, I..

${ }^{121}$ Roppo, V,; Il Contratto, cit., p. 425. “[...] quanto più bassa è la definizione del tipo, tanto maggiore è la sua elasticità.". 
nossa). No caso brasileiro, o tipo legal da empreitada é mais elástico que o italiano ${ }^{122} \mathrm{e}$ mesmo que o alemão ${ }^{123}$ e o francês ${ }^{124}$, por ser menos detalhado e não conter a definição de empreitada - portanto tem maiores condições de abrigar os contratos de engineering.

Nesse sentido, duas são as indagações que se põem e que se refletem sobre o engineering em relação à disciplina aplicável: a) a distinção entre obrigações de meio e resultado é, em si, problemática ${ }^{125}$, sendo muitas vezes difícil a submissão de dada obrigação a um ou outro tipo ${ }^{126} \mathrm{e}$; b) a possibilidade de variação do objeto do contrato no curso da obra (ius variandi), poder tipicamente atribuído ao dono da obra ${ }^{127}$, pode tornar instável o vínculo contratual. A conjunção dessas indagações constitui fator de dificuldade na definição do regime jurídico aplicável, tendo em vista que o desequilíbrio de uma obrigação de resultado produz efeitos diversos do desequilíbrio da obrigação de meio ${ }^{128}$.

${ }^{122}$ Código Civil italiano, Appalto - arts. 1655 a 1677 - in Il Codice Civile Illustrato, Piacenza, Casa Editrice La Tribuna, 2006, organização Maggese, F. e Pepe, I..

${ }^{123}$ Código Civil alemão - BGB - Werkvertrag - $\S \S 631$ a 651 - Patti, S (coord.), Codice Civile Tedesco, Milão Giuffrè, , 2005.

${ }^{124}$ Código Civil francês - Louage d'ouvrage (ou contrat d'entreprise) -arts. $1710 ; 1779$, $3^{\circ}$; e 1787 a 1799 1 - http://www.legifrance.gouv.fr/WAspad/UnCode?code=CCIVILL0.rcv (acessado em 15.06.2006).

${ }^{125}$ Vide Cavallo Borgia, op. cit., p. 112

${ }^{126}$ A título de mera ilustração, pense-se na atividade de fiscalização de obras. Em que medida a obrigação de fiscalização é de meio ou de resultado? As respostas podem variar em função do controle que o fiscal tem sobre a atividade fiscalizada. No entanto, a má-fiscalização não produz efeitos idênticos ao da má execução da atividade fiscalizada. Para o executor da atividade fiscalizada, as conseqüências dos inadimplemento seguem regime diverso do inadimplemento por parte do fiscal. Da mesma forma, é problemática a submissão da fiscalização à disciplina do mandato.

${ }^{127}$ Vide Lapertosa, Flavio; op. cit., p. 122 e Cavallo Borgia , op. cit., p. 77.

${ }^{128}$ Vale a pena ilustrar a dificuldade com um caso norte-americano: em National Presto Industries, Inc. v. United States, o empreiteiro (National Presto), em um contrato a preço fixo, buscou ressarcimento quando seus custos aumentaram substancialmente em vista de que e o método construtivo que se pretendia utilizar não se mostrou viável para produção em massa. A corte considerou que ambas as partes haviam incidido em erro no sentido de que o empreiteiro e o governo americano consideraram que a método construtivo específico em que este último tinha interesse efetivamente poderia ser usado (e, a final, não era viável). Geralmente, nos Estados Unidos, reportam Sweet e Schneier, o remédio em caso de erro mútuo quanto a pressupostos básicos do negócio é a liberação da parte responsável pela execução - no caso, o empreiteiro da obrigação de cumprimento da prestação. Mas a Court of Claims estendeu a reforma além de sua função normal de correção de erros para alterar o esquema negocial de contrato a preço fixo para esquema de empreendimento comum (joint enterprise) em que cada empreendedor (assim considerados o governo americano e o empreiteiro) dividiria as despesas imprevistas. A obrigação do empreiteiro, inicialmente de resultado, transmudou-se radicalmente (vide Sweet, Justin e Schneier; Legal Aspects of Architecture, Engineering and the Construction Process, Toronto, Thomson Canada, $7^{\mathrm{a}}$ ed. 2004, p. 428) 
Como a obrigação de resultado refere-se à consecução de um estado de coisas, mensurável e prescrito em contrato, e a obrigação de meio refere-se à conduta, ou comportamento, da parte obrigada, a quebra do equilíbrio entre as prestações refere-se, no primeiro caso (resultado) à avaliação dos custos incorridos pelo empreiteiro em vista do alcance do resultado pretendido; e, no segundo caso (meio), à avaliação dos custos incorridos pelo empreiteiro para manutenção de sua conduta ou comportamento. Como intuitivamente se percebe, a avaliação do custo econômico para se alcançar um resultado é muito mais direta que a avaliação do custo para se manter um comportamento ${ }^{129}$. Nesse ponto específico, mostra-se evidente que um dos fatores evolutivos que culminaram na tipicidade social dos contratos de engineering, construída a partir da adoção de contratostipo, também tem por função os esclarecimentos dessas questões pelo regulamento contratual específico.

Em conclusão às considerações expendidas neste capítulo, verificase que os contratos de engineering, como regra geral, submetem-se à disciplina da empreitada. Caso se imagine a possibilidade de celebração de hipotético contrato de engineering independentemente da assinatura de instrumento escrito - já que não se trata de contrato formal - parece não haver dúvida que o regime jurídico da empreitada seria plenamente aplicável, desde que houvesse o cumprimento do requisito de habilitação legal.

Da perspectiva contrária, em caso de conflito entre disposições dos contratos de engineering e disposições do regramento da empreitada, será necessário perquirir a respeito da eficácia da norma em conflito. A título de exemplo, muitas vezes ocorre que contratos de engineering possuam, em seu programa, cláusulas de limitação ou exclusão de responsabilidade. Ocorre que o prazo do artigo 618 do Código Civil, que sucedeu o artigo 1.245 do Código Civil de 1916, e trata da garantia qüinqüenal do empreiteiro de materiais e lavor pela solidez e segurança do edifício ou outras construções consideráveis, é irredutível e considerado de ordem pública ${ }^{130}$. Dado esse panorama, a definição do regime jurídico aplicável aos contratos de engineering produz impacto

\footnotetext{
${ }^{129}$ Ressalte-se ainda que a distinção entre obrigações de meio e resultado torna-se extremamente movediça em casos de evolução da tecnologia empregada. O que antes era obrigação de meio frequentemente evolui para uma obrigação de resultado.

${ }^{130}$ A esse respeito, vide Ancona-Lopez, T., Comentários ao Código Civil - Parte Especial - Das Várias Espécies de Contratos; vol. 7; São Paulo, Editora Saraiva, 2003, p. 299; que menciona ter sido "Uma importante questão foi resolvida no novo Código. O prazo de cinco anos de que cuida o art. 618 é realmente de ordem pública e não poderá ser reduzido pelas partes (utiliza o legislador o termo 'irredutível')".
} 
relevante na alocação dos riscos e responsabilidades das partes, questão que se analisará na segunda parte deste trabalho. 
3 APLICAÇÃO DA TEORIA DA ONEROSIDADE EXCESSIVA AOS CONTRATOS DE ENGINEERING 


\subsection{A FLEXIBILIZAÇÃO DO VÍNCULO CONTRATUAL}

Aplicando a metáfora de Coase citada na passagem transcrita no Capítulo 1 - Introdução, acima, os contratos podem ser considerados os neurônios do sistema econômico e, como tais, vêm passando por grande reconfiguração durante o transcurso dos séculos, amoldando-se à evolução econômica e social em movimento que tende à sua flexibilização. $\mathrm{O}$ debate entre os que consideram que o contrato tem como substrato um dever moral de cumprimento ${ }^{131}$ e os que o consideram apenas a "veste" de uma operação econômica, um instrumento das trocas econômicas sujeito às considerações de eficiência alocativa de recursos ${ }^{132}$ já é antigo, mas mostra a evolução do debate que vem se travando entre rigidez e flexibilidade do vínculo do ponto de vista moral e filosófico.

A discussão referida é acompanhada, do ponto de vista da Teoria Econômica, pela trajetória que parte da Economia Clássica, pela qual a análise dos contratos era considerada sob a premissa de que estes são sempre completos, ou seja, prevêem soluções para todas as contingências futuras, e que seu cumprimento não envolveria custos relevantes, e chega à Nova Economia Institucional, em que os pressupostos da ortodoxia econômica são colocados em cheque e os contratos deixam de ser analisados sob a perspectiva de sua completude, sob o fundamento de que as partes

${ }^{131}$ Expoente dessa corrente, nos EUA, é Charles Fried, que afirma:

Critics of the promise principle have found theoretical support for their attacks in the sometimes abrupt reversals of fortune that the principle brings about. Instrumentalists of every sort - whether economists or those moved by a vague altruistic or socializing attitude-tend to abhor such sharp peripeties. If we take autonomy seriously as a principle for ordering human affairs, however, people must abide by the consequences of their choices, and this imperative will give the ensuing outcomes a discontinuous, binary quality. Whether or not a person has promised is a yes or no question. If he has, he is judged by the regime of promise. If he has not, some other regime controls. And if a person has given a promise and received one in return, his repudiation of his promissory obligations will deprive him of the title to insist that his own claims be judged under that promissory regime. It is crucial to be in the right.

Fried, C.; Contract as Promise - A Theory of Contractual Obligation, Cambridge, Harvard University Pres, 1981, p. 113.

${ }^{132}$ Para um apanhado das teorias em um e outro sentido e defesa do utilitarismo contratual vide Shavell, S., IS Breach of Contract Immoral?,. Harvard Law and Economics Discussion Paper No. 531, nov/2005, http://ssrn.com/abstract $=868592$ (consultado em 10.01.2006) 
podem deixar de celebrar contratos completos em vista de limitações de racionalidade ${ }^{133}$, das incertezas do futuro, de incorrerem em custos elevados para prever e negociar sobre todas as hipóteses possíveis e dos custos de incorridos na execução desses mesmos $\operatorname{contratos}^{134}$.

Abaixo, essa evolução é descrita sob a perspectiva jurídica.

\subsubsection{Da santidade dos pactos à efficient breach}

A força obrigatória do contrato adentra à modernidade com o Código de Napoleão, de 1804, que, em seu artigo $1134^{135}$, instaura o princípio segundo o qual "o contrato tem força de lei”, dando margem à solidificada noção do contrato como fonte de obrigações a partir do estabelecimento de vínculo jurídico imutável entre as partes.

Como lembra Roppo ${ }^{136}$, a idéia de vínculo contratual melhor se traduz em conexão com a noção de efeitos do contrato, resultando ser esse vínculo propriamente referido à sujeição das partes a esses efeitos. Essa sujeição é, no entanto, em muitos casos, afastada pelo rompimento do vínculo contratual, o que se dá, por exemplo, nos casos em que a lei prevê a possibilidade de resolução contratual por seu descumprimento por uma das partes (artigo 475 do Código Civil). A mesma sujeição também é afastada ao se abrir a possibilidade de renegociação ou revisão do contrato, como no caso da renegociação por consenso entre as partes, ou por fatores externos ao contrato que possam ter impedido o pleno desenvolvimento da execução contratual.

\footnotetext{
${ }^{133}$ Tradução livre da expressão inglesa bounded rationality.

${ }^{134}$ Nicita, A. e Pagano, U ; Incomplete contracts and institurions, in The Elgar Companion to Law and Economics, ed. Backhaus, J., Cheltenham, Edward Elgar Publising, Inc., 2005, p.p. 145-146.

${ }^{135}$ Artigo 1134 do vigente Código Civil francês: "Les conventions légalement formées tiennent lieu de loi à ceux qui les ont faites. Elles ne peuvent être révoquées que de leur consentement mutuel, ou pour les causes que la loi autorise. Elles doivent être exécutées de bonne foi." http://www.legifrance.gouv.fr/WAspad/UnCode?code=CCIVILL0.rcv (acessado em 15.06.2006).

136 Roppo, V,; op.cit., p. 531.
} 
Obviamente, não se quer aqui sistematizar ou enunciar todas as hipóteses em que as partes no contrato possam se isentar do cumprimento das obrigações nele previstas, mas, para fins deste trabalho, basta sublinhar que os ordenamentos jurídicos contratuais, em geral, prevêem duas hipóteses básicas de isenção das partes aos efeitos do contrato, como originalmente celebrado: a) ou se rompe o vínculo, ou; b) as partes o modificam, por consenso, para adaptá-lo a seus interesses ou novas situações.

Desde o Direito Romano, o modo natural e esperado de extinção das obrigações que derivam do contrato é o adimplemento (solutio), modo este fundado na identidade entre o comportamento esperado do devedor, no momento da contração da obrigação, e o resultado final de seu comportamento ${ }^{137}$, ao dar ou fazer o que se espera, nos termos do contrato. Àquela época, a força dos pactos sobrepujava noções mais flexíveis sobre o vínculo contratual. Segundo o sistema da legis actiones, ao devedor, ou réu, como resposta diante da reivindicação de efetivação do direito de crédito do autor, somente restava confessar fundada a pretensão deste último, ou rechaçá-la plenamente, com base, por exemplo, na alegação de que o crédito não seria mais existente, ou já houvesse sido pago, ou ainda remido em forma solene. Mais tarde, já no processo formular consuetudinário romano, como anota Arangio-Ruiz ${ }^{138}$, passa-se a admitir a exceptio, pela qual, não obstante houvesse o reconhecimento do direito subjetivo demonstrado pelo autor, o réu era dispensado do cumprimento da obrigação.

O mesmo Arangio-Ruiz ${ }^{139}$ anota que a base da exceptio funda-se na oposição que os romanos observavam entre os vários sistemas de normas jurídicas, como, por exemplo, ainda que o costume conferisse plena efetividade aos contratos, leis proibiam que se abusasse da inexperiência dos menores de vinte e cinco anos (como a lex Plaetoria de circumscriptione adolescentium). No formalismo romano original, a solução pretoriana consistia em se permitir a execução do contrato, como originalmente pactuado, ou seja, os credores não eram impedidos de agir contra os devedores, ainda que menores, mas uma ação poderia ser intentada contra o credor por violação da lex Plaetoria referida, com o

\footnotetext{
${ }^{137}$ Vide Arangio-Ruiz, Vincenzo, Istituzioni di Diritto Romano, Nápoles, Casa Editrice Dott. Eugenio Jovene, 1994, p. 391.

138 Arangio-Ruiz, Vincenzo, op. cit., p. 131

139 Arangio-Ruiz, Vincenzo, op. cit., p. 131
} 
efeito de infligir-lhe pena pecuniária. Com o sistema formulário, como evolução do antigo costume, dava-se ao devedor menor de vinte e cinco anos o direito de argüir exceção fundada na lex Plaetoria de circumscriptione adolescentium, para se eximir do cumprimento da obrigação, fundindo-se, assim, o antigo procedimento dúplice de ação do devedor e reação do devedor menor, por intermédio de outra ação, no procedimento unificado de ação e defesa via exceptio - com enorme simplificação procedimental e maior eqüidade decisória. Vê-se, portanto, que, segundo o reconhecido estudo citado, o Direito Romano, de início, impôs rigidez quase absoluta ao vínculo contratual, sem admitir exceções que permitissem ao devedor se escusar do cumprimento contratual sem ser sancionado. Pouco a pouco, entretanto, o sistema passa a admitir defesas fundadas em exceções, em que se vislumbra o começo de longo processo histórico em que a rigidez do vínculo contratual passa a ser gradativamente mitigada.

Não obstante, em artigo frequentemente citado, Osti ${ }^{140}$, referindo-se à época romana, já encontrava fundamentos filosóficos para a identificação da existência da cláusula rebus sic standibus em passagens dos jurisconsultos Cícero ${ }^{141} \mathrm{e}$, também,

\footnotetext{
${ }^{140}$ Osti, Giuseppe, "La cosi detta clausola 'rebus sic stantibus' nel suo sviluppo storico”, Rivista de Diritto Civile, Anno IV, 1912, pp. 1-58, que diz, à p. 10, sobre "De Officii" e "De Beneficii" e sua influência sobre o desenvolvimento da cláusula rebus,:
}

\begin{abstract}
Ma poi, quelle due trattazioni filosofiche - quasi affatto dimenticate dagli autori moderni - hanno una importanza particolarissima per il nostro argomento, anche e sopratutto per l'influenza che esse esercitarono sul sorgere della teoria di cui stiamo occupandoci: influenza cosi preponderante, per non dire esclusiva, e cosi immediata - come dimostreremo - che induce a vedere in dette trattazioni (o per meglio dire nella rinnovata voga che esse conseguirono quando, per le note affinità, fra la filosofia cristiana e la filosofia stoica cui esse sono inspirati, quest'ultima fu rimessa in onore dalla Scolastica) il punto de partenza del particolare movimento di pensiero che mette capo alla teoria giuridica della clausola rebus sic stantibus
\end{abstract}

141 Cícero, em seu "De Officii” dizia (Cícero, Marco Túlio, "De Officii” (“Dos Deveres”), Livro I, cap. X, p. 18, Martins Fontes, 1999): Livro I, Capítulo X:

Pode acontecer, com efeito, que uma promessa ou pacto se torne inútil ao beneficiário ou a quem o prometeu. Se, como lemos na fábula, Netuno não houvesse cumprido a promessa a Teseu, este não teria sido privado do filho Hipólito - pois dos três desejos, segundo o relato, foi com o terceiro que ele exigiu colericamente a morte do rapaz. Atendido, mergulhou em pesado luto. Não devem, assim, ser mantidas promessas que se revelam inúteis a quem se destinam; e se mais te prejudicarem que favorecerem aquele a quem as fizeste, fica sabendo que não é contrário ao dever antepor o bem maior ao menor. Quando te houveres constituído em advogado de alguém numa causa premente e, nesse ínterim, teu filho contrair moléstia grave, não ofenderás o dever deixando de cumprir o que prometeste; e aquele a quem o prometeste, esse sim fugiria ao dever se se queixasse de abandono.” 
Sêneca ${ }^{142}$, cujos escritos conferiam grande latitude à possível exceção do réu caso as circunstâncias existentes à época da formulação da promessa houvessem se alterado.

E, no Livro III, Capítulo XXV:

94. Em verdade, não devem ser cumpridas as promessas que não são úteis aos beneficiários. O Sol, para voltarmos às fábulas, disse a seu filho Faetonte que faria tudo que ele quisesse; e ele quis conduzir o carro do pai. Subiu nele mas, antes de firmar-se, foi consumido por um raio. Quão melhor seria se o pai não cumprisse a promessa! Que dizer da Promessa de Netuno que Teseu reclamou? Netuno lhe apresentara três desejos à escolha e Teseu desejou a morte de seu filho Hipólito, suspeito de cortejar a madrasta. Realizado o desejo, Teseu mergulhou em pesado luto. 95. E Agamenão? Tendo consagrado a Diana aquilo que de mais belo nascesse aquele ano em seus domínios, sacrificou Efigênia, nascida justamente então, e que nada superava em formosura. Mais valia não cumprir a promessa que concordar com crime tão hediondo. Portanto, nem sempre é bom cumprir as promessas ou devolver os depósitos. Se alguém que te confiou dinheiro fizer a guerra contra a pátria, devolverás o depósito? Não, penso eu, pois assim agirias contra a república, que deve constituir a principal afeição. Assim, muitas coisas que parecem honestas por natureza tornam-se, conforme as circunstâncias, desonestas. Cumprir promessas, aferrar-se aos acordos e devolver os depósitos deixam de ser ações honestas quando já não são úteis.

${ }^{142}$ Seneca, Lucius Annaeus, "De Beneficiis", Livro IV, cap. XXIV (parte final) e XXXV - Tradução de Aubrey Stewart, 1887, disponível em: http://www.gutenberg.org/dirs/etext03/bnfts10.txt,:

The wise man never changes his plans while the conditions under which he formed them remain the same; therefore, he never feels regret, because at the time nothing better than what he did could have been done, nor could any better decision have been arrived at than that which was made; yet he begins everything with the saving clause, "If nothing shall occur to the contrary." This is the reason why we say that all goes well with him, and that nothing happens contrary to his expectation, because he bears in mind the possibility of something happening to prevent the realization of his projects. It is an imprudent confidence to trust that fortune will be on our side. The wise man considers both sides: he knows how great is the power of errors, how uncertain human affairs are, how many obstacles there are to the success of plans. Without committing himself, he awaits the doubtful and capricious issue of events, and weighs certainty of purpose against uncertainty of result. Here also, however, he is protected by that saving clause, without which he decides upon nothing, and begins nothing.

$X X X V$. When I promise to bestow a benefit, I promise it, unless something occurs which makes it my duty not to do so. What if, for example, my country orders me to give to her what I had promised to my friend? or if a law be passed forbidding any one to do what I had promised to do for him? Suppose that I have promised you my daughter in marriage, that then you turn out to be a foreigner, and that I have no right of intermarriage with foreigners; in this case, the law, by which I am forbidden to fulfill my promise, forms my defense. I shall be treacherous, and hear myself blamed for inconsistency, only if I do not fulfill my promise when all conditions remain the same as when I made it; otherwise, any change makes me free to reconsider the entire case, and absolves me from my promise. I may have promised to plead a cause; afterwards it appears that this cause is designed to form a precedent for an attack upon my father. I may have promised to leave my country, and travel abroad; then news comes that the road is beset with robbers. 
Do ponto de vista filosófico, é interessante notar que o modelo jurídico de rigidez absoluta do vínculo contratual encontra sua mais absoluta realização no Direito Romano com a redução do devedor insolvente à condição de escravo ${ }^{143}$. Sumner Maine $^{144}$ sublinha a severidade extraordinária com que os devedores nos sistemas legais muito antigos eram tratados, em contraposição aos extraordinários poderes conferidos aos credores. À época, dizia Maine ${ }^{145}$, a "insolvência era sem dúvida considerada como uma anomalia e a suspensão de pagamento em geral, um artifício e distorção da regra estrita." (tradução nossa). Por oposição, nada mais natural que conferir poderes extravagantes ao credor que, uma vez tendo cumprido sua parte na transação via-se em situação de peculiar vantagem social, passando a gozar de instrumental exorbitante para a execução de procedimentos de cobrança. Ora, pode-se extrair dessa tradição que o princípio do pacta sunt servanda encontrava seu apogeu em um sistema em que o descumprimento de obrigações tinha por sanção a supressão da própria liberdade.

Quando se raciocina em termos de quid pro quo, cumprida a obrigação por uma das partes, espera-se, como natural, o cumprimento da contraprestação. Entretanto, especialmente em contratos de duração, essa lógica é quebrada na medida em que o devedor pode não estar lançando mão de um artifício para deixar de pagar. Antes pode estar em situação de objetiva impossibilidade de adimplir, em vista de contingências fora de seu controle.

Por essa razão, o problema da rigidez do vínculo contratual se põe de maneira mais evidente em relação ao contrato de longa duração, em que o decurso do

\footnotetext{
I was going to an appointment at some particular place; but my son's illness, or my wife's confinement, prevented me. All conditions must be the same as they were when I made the promise, if you mean to hold me bound in honour to fulfill it. Now what greater change can take place than that I should discover you to be a bad and ungrateful man? I shall refuse to an unworthy man that which I had intended to give him supposing him to be worthy, and I shall also have reason to be angry with him for the trick which he has put upon me.
}

\footnotetext{
${ }^{143}$ Alves, J. C. M. Direito Romano, v. II, 5a. ed., Rio de Janeiro: Forense, 1995, pp. 99-100.

${ }^{144}$ Maine, H.S.; Ancient Law - Its Connection with th Early History of Society and its Relation to Modern Ideas, Dorset Press, 1986, p. 267.

${ }^{145}$ Maine, H.S.; idem.
} 
tempo leva ao aparecimento de contingências que afetam sua execução. Certo é que a dogmática e a jurisprudência sempre desempenharam a função de acomodação entre a rigidez normativa, que resultava na intangibilidade do vínculo contratual, e a flexibilidade necessária à convivência entre diferentes sistemas normativos (como no caso acima relatado, do Direito Romano), ou a adaptação do pactuado à alteração superveniente das circunstâncias. Mesmo no Direito Romano, estudiosos afirmam que já se exculpava o devedor do pagamento da dívida na ocorrência de casos fortuitos ou de força maior ${ }^{146}$, cuja incidência está inevitavelmente ligada ao decurso do tempo entre a contração da dívida e seu pagamento.

Dessa maneira, verifica-se que um dos primeiros passos em direção à flexibilização do vínculo contratual decorreu da consideração dos efeitos de casos fortuitos ou de força maior como causas de flexibilização do vínculo contratual. A etapa seguinte viria com a teoria da imprevisão ${ }^{147}$.

Em grande salto histórico, na França, como reporta Darcy Bessone ${ }^{148}$, a Corte de Cassação resistia "tenazmente às solicitações de revisão dos contratos". Não obstante, a Lei Failliot, de 1918, veio a reconhecer que "durante o conflito [I Guerra Mundial] e até três meses depois de cessadas as hostilidades, os contratos comerciais celebrados antes de $1^{\circ}$ de agosto de 1914 , cujo cumprimento se desse do futuro, poderiam ser resolvidos, ainda que não ocorresse qualquer das causas de resolução estabelecidas pelo

${ }^{146}$ Alves, J. C. M; op. cit.; p. 46.

${ }^{147}$ Força maior ou caso fortuito geralmente referem-se a eventos externos ao contrato que produzem efeitos sobre seu cumprimento, a onerosidade excessiva também se refere a esses mesmos efeitos externos. A distinção entre ambos os institutos, segundo Medeiros da Fonseca (*), expoente dessa doutrina, decorre do elemento subjetivo, do campo de aplicação e do requisito de que o evento externo, no caso da onerosidade excessiva, não tenha impossibilitado a prestação, mas tornado, como o próprio termo diz, mais onerosa sua efetivação. Ou seja, enquanto que a aplicação da norma de exoneração da responsabilidade por ocorrência de caso fortuito supõe a ocorrência de evento externo ao sujeito que impossibilite absoluta ou objetivamente o cumprimento da prestação, isto é, impeça a efetivação da prestação por qualquer indivíduo colocado em situação análoga à do obrigado em vista da inevitabilidade do evento; a aplicação da norma relativa à onerosidade excessiva também não dispensa a ocorrência de evento externo ao sujeito, "mas atende também à impossibilidade subjetiva ou onerosidade excessiva da prestação". Para o referido Autor, ocorrência de hipótese de força maior, por seu turno, libera o devedor da responsabilidade de cumprimento da prestação, parcial ou totalmente, permanente ou temporariamente; já no caso da onerosidade excessiva, em vista da alteração radical do ambiente objetivo existente ao tempo da formação do contrato não existe necessariamente liberação do devedor excessivamente onerado, caso haja reparação, ou revisão do contrato.

(*) Fonseca, A. M; Caso Fortuito e Teoria da Imprevisão, Forense, Rio de Janeiro, $3^{\text {a }}$ ed., 1958, p. 346.

${ }^{148}$ Bessone, Darcy; op. cit., p. 282 
Direito comum ou convencionadas pelas partes, se, em virtude do estado de guerra, a execução das obrigações de qualquer dos contratantes lhe causasse prejuízos cuja importância excedesse de muito as previsões que pudessem razoavelmente ser feitas ao tempo da convenção."149

A tradição francesa, com efeito, sempre se pautou pela preponderância do princípio da imutabilidade das convenções. Como afirma o tratado dirigido por Jacques Ghestin ${ }^{150}$, a regra pacta sunt servanda aparece como tradução concreta da concepção voluntarista do contrato e se justifica pela segurança que aporta às relações. Ghestin menciona que o contrato constitui justamente um ato de previsão e, citando Ripert, "une emprise sur l'avenir", uma determinação ou influência sobre o futuro. Ou seja, a imprevisão constitui a antítese da previsão do futuro, função básica do contrato. Historicamente, lembra ainda Ghestin, citando Louveau, o artigo 1.134 do Código Civil Francês, já mencionado, é uma reação contra a atitude dos parlamentos do Ancien régime $^{151}$, constituindo, assim, uma regra de competência, vedando ao juiz toda interferência sobre o contrato a fim de se evitar a arbitrariedade.

Mais do que uma explanação jurídico-teórica ou histórica para a ênfase ao princípio da imutabilidade das convenções, do ponto de vista sócio-econômico, o vínculo contratual imutável propiciaria às partes situação de certeza e segurança conferida pela imutabilidade dos pactos, com redução dos custos de transação ${ }^{152}$. A Revolução

\footnotetext{
${ }^{149}$ Bessone, Darcy, op. cit., pp. 282-283.

${ }^{150}$ Guestin, Jacques, Jamin, Christophe e Billiau, Marc; Traité de Droit Civil-Les Effets du Contrat, Paris, L.G.D.J., $2^{\mathrm{a}}$ ed., 1994, pp. 316-317.

${ }^{151}$ Guestin, Jacques et alii., op. cit., nota de rodapé 41, p. 317: “Cd. A. Louveau, th. Précité, p. 50-51:
}

Le Code civil, par réaction contre l'ancien état de chose, et notamment par la crainte des arrêts de règlement des Parlements, a voulu, manifestant à l'égard du juge une grande défiance, amoindrir son rôle. Il n'avait pas oublié la fameuse apostrophe: 'Dieu nos garde de l'équité des Parlements!'. "Ce cri de la conscience publique, écrit Laurent, révèle l'esprit de nos lois modernes'.

${ }^{152}$ Vide, a esse respeito, North, D..; Institutions, Transaction Costs and the Rise of Merchant Empires, in The Political Economy of Merchant Empires, James D. Tracy, editor, Cambridge University Press, Cambridge, 1997, pp. 27 e 29-30. Para North, as inovações trazidas pela ascensão dos impérios mercantis europeus que reduziram custos de transação consistiram em inovações organizacionais, instrumentos e técnicas específicas e características de execução de obrigações que reduziram os custos de troca a longas distâncias. Essas inovações específicas e instrumentos institucionais se desenvolveram a partir da interação de duas forças econômicas. Uma delas referia-se às economias de escala associadas com o volume crescente de comércio; a outra, foi o desenvolvimento de mecanismos de execução de obrigações (enforcement) que tornaram possível 
Francesa, com seu caráter de revolução burguesa, fazia com que as leis incorporassem expedientes que diminuíssem a incerteza e tornassem mais ágeis os procedimentos de execução dos contratos e circulação do crédito. Se os juízes interferissem menos no andamento das questões contratuais postas, haveria menos dúvidas negociais e, consequentemente, maior calculabilidade ${ }^{153}$, com redução de custos de transação e aumento do tráfico comercial.

Esse movimento dialético ${ }^{154}$ entre a imutabilidade do vínculo contratual e sua flexibilização parece hoje voltar-se para a antítese do pacta sunt servanda. Mostra dessa tendência é assinalada, em certa medida, pela influência, ao menos teórica e, sobretudo ventilada nos Estados Unidos, da teoria da efficient breach, ou, à falta de melhor tradução, rompimento economicamente eficiente do vínculo contratual. Vincenzo Roppo $^{155}$, ao refletir sobre o que será do contrato nos anos 2000, ressalta - talvez

a execução de contratos a custos menores. Esses mecanismos de aperfeiçoamento da execução de contratos se desenvolveram durante longo processo em que não somente várias cortes lidavam com disputas comerciais, mas em que os próprios mercadores desenvolveram mecanismos de execução, como códigos de conduta, entre outros. Na esteira da linha de raciocínio de North, pode-se argumentar que essa evolução já mostrava os caminhos finalmente incorporados ao Código de Napoleão com a consagração do pacta sunt servanda.

${ }^{153}$ Weber, Max, Economía y Sociedad, Fondo de Cultura Económica, México, 1987: “El poderío universal de la sociedad que constituye el mercado demanda, por un lado, un funcionamiento del derecho calculable según reglas racionales."

${ }^{154}$ Vide Roppo, Vincenzo,, Il Contratto, cit., pp. 1016-7:

La dialettica fra rilevanza liberatoria delle sopravvenienze e principio del vincolo contrattuale è - nella prospettiva degli interessi delle parti-tensione fra ansia de liberazione della parte gravata e aspettativa/affidamento di controparte circa la prestazione promessale. Alla luce di questa stessa tensione, il rilievo delle sopravvenienze entra in dialettica con un altro principio (complementare a quello del vincolo): il principio d'irrilevanza dei motivi, e più specificamente d'irrilevanza dell'errore sui motivi. Tant'è vero che in quest'area di tendenziale irrilevanza ricade l'errore di precisione, che non è altro se non ignoranza o falsa conoscenza, al tempo del contratto, delle future sopravvenienze.

${ }^{155}$ Roppo, Vincenzo, “Il Contratto del Duemila”, G. Giappichelli Editore, 2002, pp. 78-79:

Nella tradizione europea, l'idea di contratto è indissociabile dall'idea di vincolo contrattuale: "Il contratto ha forza di legge tra le parti" (art. 1372, $1^{\circ}$ comma, prima parte, cod. civ.). Tecnicamente, l'idea significa resistenza del contratto al pentimento unilaterale della parte, impossibilità per la parte di distruggere unilateralmente il contratto: "Il contratto ... Non può essere sciolto che por mutuo consenso o per causa ammesse dalla legge” (art. 1372, $1^{\circ}$ comma, seconda parte, cod. civ.). Sul piano ideologico, l'idea del vincolo riflette un imperativo che appartiene alla morale prima che al diritto: "pacta sunt servanda".

Negli sviluppi del pensiero giuridico europeo, il vincolo contrattuale può essere stato messo in discussione con riferimento alle sue condizioni e ai suoi 
imprimindo à descrição da tendência apontada cores mais fortes do que as que realmente tem ${ }^{156}$ - que o pensamento jurídico americano é permeável à idéia de que as partes não são obrigadas a cumprir o contrato, mas têm a opção de cumpri-lo, ou pagar a indenização pactuada, colocando-se a alternativa entre o adimplemento ou o inadimplemento em área de indiferença axiológica. ${ }^{157}$

limiti: si è discusso quando il vincolo possa dirsi sorto, e se la soglia della sua costituzione debba essere più avanzata o più arretrata; si è discusso in presenza di quali circostanze una parte possa aspirare a liberarsi dal vincolo pur validamente assunto; e così via. Ma mai si è sfidato il vincolo come tale, nel suo valore de elemento identificativo del contratto - del suo senso, della sua ragion d'essere.

Questa sfida è stata lanciata, invece, nel mondo nel mondo di common law: più precisamente, nel mondo del common law americano. Nell'arco di un intero secolo - dalle vecchie suggestioni di Oliver $W$. Holmes alla spirare del $X I X$, fino alle più estreme teorie dell'efficient breach elaborate alla fine de XX dai cultori dell'analisi economica del diritto - il pensiero giuridico americano è stato attraversato da un'idea: dal contratto non derivano per le parti obblighi di adempimento, ma poderi di scelta fra le adempimento $e$ inadempimento/risarcimento; l'opzione fra adempimento e inadempimento si colloca in un'area d'indifferenza assiologica, riducendosi ad apprezzamenti di pura convenienza economica, perché la violazione del contratto merita di essere considerata "migliore" del suo rispetto tutte le volte che garantisca una "migliore" allocazione delle risorse.

Ne esce, con chiarezza, una figura di contratto che rifiuta l'idea del vincolo, disconosce la sacertà del principio "pacta sunt servanda", si estrania totalmente dalla metafora della "forza di legge.

${ }^{156}$ A real existência da tendência é contestada por Joseph Perillo, influente autor de direito americano dos contratos do século XX e co-autor de um dos mais reputados manuais acadêmicos sobre o tema, naquele país. Com efeito, Perillo, in "Misreading Oliver Wendell Holmes on Efficient Breach and Tortious Interference", Fordham Law Review, Vol. 68, 2000, http://ssrn.com/abstract=241263, escreve o seguinte:

In a letter, Holmes chided Pollock for this passage and clarified his meaning "I stick to my paradox as to what a contract was at common law; promise to pay damages, or, etc., but an act imposing a liability to damages nisi you commit a tort \& are liable. You commit a contract and are liable unless the event agreed upon, over which you may have no, and never have absolute, control, comes to pass.' Thus, Holmes equates a contractual breach with a tort, and we know that the word "tort" is law French for "wrong." Consequently, in Holmes' view, the breach of a contract was as much an offense against the law - a legal wrongas a tort, not the free choice that Holmes' misinterpreters believe he advocated. Indeed, from the bench, Holmes described a breach of contract as a wrong. In his judicial capacity, he certainly approved of the grant of expectancy damages, and allowed a price action where the seller had deposited securities in escrow, but the buyer refused to pay - in essence, specific performance at law.

${ }^{157}$ Conforme exposto na nota anterior, a idéia de indiferença axiológica que supostamente permeia o pensamento jurídico americano está longe de ser amplamente aceita, mesmo pelos autores norte-americanos mais afinados com a chamada Análise Econômica do Direito. Vide, a esse respeito, Shavell, Steven; Is Breach of Contract Immoral?, Harvard John M. Olin Discussion Paper Series, discussion paper $\mathrm{n}^{\circ} 531$, disponível em http://www.law.harvard.edu/programs/olin_center/ 
Como se vê, a noção de vínculo contratual vem passando por reavaliação profunda do ponto de vista de sua funcionalidade. Se é certo que a teoria da efficient breach se situa no campo da eficiência alocativa e representa um modelo de análise da situação das partes em dado estágio do cumprimento do contrato - ou seja, a teoria é mais um instrumento de análise econômica do contrato do que um princípio geralmente aceito, mesmo nos Estado Unidos - é indiscutível que a noção de vínculo contratual passa por discussões que possivelmente a levarão a um plano de maior flexibilidade do que a conferida pela dogmática tradicional.

Cabe, então, pesquisar o porquê da necessidade de flexibilização do vinculo contratual de duração, da mitigação da "santidade dos pactos". Para tanto, é necessário, em relação aos contratos de engineering, aprofundar a análise dos problemas encontrados na alocação de riscos contratuais.

\subsubsection{Notas sobre a introdução do remédio da onerosidade excessiva no Brasil e a experiência do direito comparado}

O Novo Código Civil brasileiro introduziu no ordenamento jurídico disposições que tratam da resolução do contrato por onerosidade excessiva. Em termos resumidos, nos contratos de execução continuada ou diferida, essas disposições permitem ao contratante buscar a resolução ou renegociação do contrato, se a prestação de uma das partes se tornar excessivamente onerosa, com extrema vantagem para a outra, em virtude de acontecimentos extraordinários e imprevisíveis. A consideração da possibilidade de resolução do contrato por onerosidade excessiva se contrapõe, como visto anteriormente e do ponto de vista lógico, ao princípio da força obrigatória dos contratos, um dos pilares da teoria geral dos contratos. Embora não seja objetivo deste trabalho analisar dogmaticamente as diversas teorias sobre a superveniência contratual - de resto já estudadas em obras como as de Medeiros da Fonseca ${ }^{158}$ e Karl Larenz ${ }^{159}$, entre outros -

\footnotetext{
${ }^{158}$ Medeiros da Fonseca, A., Caso Fortuito e Theoria da Imprevisão, Rio de Janeiro, Forense, $3^{\text {a }}$ ed., 1958.

${ }^{159}$ Larenz, K.; Base del Negocio Jurídico y Cumplimiento de los Contratos, Granada, Editorial Comares, 2002
} 
não se pode tratar da flexibilização do vínculo contratual sem que se passe pelo direito positivo nacional e comparado.

O tratamento sobre a onerosidade excessiva contido em nosso vigente Código Civil é, salvo omissão de certa parte ${ }^{160}$, bastante semelhante ao tratamento dispensado ao mesmo tema no Código Civil italiano. Com efeito, os artigos 478 a 480 do Código Civil brasileiro são tradução praticamente literal das disposições constantes dos artigos 1.467 e $1.468^{161}$ do Código Civil italiano de 1942. Sessenta anos após a introdução

${ }^{160}$ O parte referida é: "La risoluzione non può essere domandata se la sopravvenuta onerosità rientra nell'alea normale del contratto." [in Il Codice Civile Illustrato, Piacenza, Casa Editrice La Tribuna, 2006, organização Maggese, F. e Pepe, I., pp. 936]. A omissão dessa parte no Código brasileiro é lamentável porque sua noção se liga à "tipologia e medida" do risco, dando ao intérprete a clara orientação de que o risco específico de cada operação econômica veiculado pelo contrato deve ser examinado. É nesse sentido que Roppo discorre [Il Contratto, Milão, Giuffré, 2001, p. 1024]:

Ogni contratto espone le parti a qualche rischio: alea normale de contratto è la tipologia e la misura del rischio che la parte implicitamente si assume col contratto (implicitamente, perché se l'assunzione del rischio fosse esplicitata in una clausola, il regime della sopravvenienza discenderebbe dalla volontà delle parti e non dalla legge).

Essa dipende in primo luogo dal tipo contrattuale, giacché ogni tipo incorpora un diverso piano di ripartizione dei rischi fra i contraenti: chi deve fornire un manufatto assume rischi diversi, a seconda che prometta la fornitura a titolo di appalto o di vendita (di cosa futura); diverso è il rischio assunto da chi deve fornire servizi, a seconda che s'impegni con un contratto d'opera o di lavoro subordinato o di agenzia.

Ma alla considerazione del tipo deve aggiungersi l'apprezzamento di ogni altro dato personalizzante che concorra a disegnare il piano di ripartizione dei rischi concretamente adottato dalle parti (il particolare oggetto del contratto; clausole estranee alla disciplina del tipo, negoziate ad hoc; la specifica congiuntura di mercato in cui il contratto s'inserisce; ecc.). Cosi, se il contratto appartiene a un mercato dove sono abituali violente oscillazioni dei prezzi (si pensi alla borsa), potrà rientrare nell'alea normale una misura di squilibrio che sarebbe invece da considerare « eccessiva» in mercati più tranquilli.

Sezione III - Dell'eccessiva onerosità

Art. 1467 Contratto con prestazioni corrispettive

Nei contratti a esecuzione continuata o periodica ovvero a esecuzione differita, se la prestazione di una delle parti è divenuta eccessivamente onerosa per il verificarsi di avvenimenti straordinari e imprevedibili, la parte che deve tale prestazione può domandare la risoluzione del contratto, con gli effetti stabiliti dall'art. 1458 (att. 168).

La risoluzione non può essere domandata se la sopravvenuta onerosità rientra nell'alea normale del contratto.

La parte contro la quale è domandata la risoluzione può evitarla offrendo di modificare equamente le condizioni del contratto (962, 1623, 1664, 1923).

Art. 1468 Contratto con obbligazioni di una sola parte

Nell'ipotesi prevista dall'articolo precedente, se si tratta di un contratto nel quale una sola delle parti ha assunto obbligazioni, questa può chiedere una riduzione della sua prestazione ovvero una modificazione nelle modalità di esecuzione, sufficienti per ricondurla ad equità. 
da regra de resolução do contrato por onerosidade excessiva no Direito Contratual italiano, o Direito brasileiro passa a prever expressamente hipótese de resolução somente ventilada, anteriormente, em sede doutrinária, com as várias derivações de aplicação da cláusula rebus sic stantibus.

No que toca à empreitada, à exemplo do artigo 1.664 do Código Civil italiano ${ }^{162}$, que dispõe sobre a revisão do contrato em caso de aumento de custo de materiais e mão-de-obra superior a dez por cento e em caso de encontro de condições geológicas desfavoráveis no solo, o Código Civil brasileiro também prevê solução bastante similar nos artigos 620 e na parte que trata de dificuldades imprevistas de execução por causas geológicas e hídricas do inciso II do art. 625 .

Esses dispositivos diferem dos artigos da parte geral de cada um desses códigos que tratam da onerosidade excessiva porque a hipótese específica de revisão já está prevista. Ou seja, em caso de aumento de custos de materiais e mão-de-obra superior a dez por cento e em caso de imprevistos geológicos, o preço será revisto. Ao contrário, os artigos 478 do Código Civil brasileiro e 1.467 do Código Civil italiano não especificam a causa da revisão sob o ponto de vista material. Na fattispecie desses artigos, a onerosidade excessiva decorre da ocorrência de eventos extraordinários e imprevisíveis, sem delimitação clara do que se entende por "imprevisível" e "extraordinário".

Os artigos citados das partes dos códigos referidos que tratam da empreitada equivaleriam a cláusulas implícitas ao contrato. $\mathrm{Na}$ dogmática que inspirou esses Códigos, poder-se-ia dizer que os dispositivos ora tratados que dizem respeito à empreitada constituiriam conceitos legais indeterminados, enquanto que as disposições

\footnotetext{
162 Artigo 1664 do Código Civil italiano[in Il Codice Civile Illustrato, Piacenza, Casa Editrice La Tribuna, 2006, organização Maggese, F. e Pepe, I., pp. 1059-1060]:
}

Qualora per effetto di circostanze imprevedibili si siano verificati aumenti o diminuzioni nel costo dei materiali o della mano d'opera, tali da determinare un aumento o una diminuzione superiori al decimo del prezzo complessivo convenuto, l'appaltatore o il committente possono chiedere una revisione del prezzo medesimo. La revisione può essere accordata solo per quella differenza che eccede il decimo (1467).

Se nel corso dell'opera si manifestano difficoltà di esecuzione derivanti da cause geologiche, idriche e simili, non previste dalle parti, che rendano notevolmente più onerosa la prestazione dell'appaltatore, questi ha diritto a un equo compenso. 
sobre onerosidade excessiva da parte geral de ditos estatutos poderiam ser caracterizadas como cláusulas gerais ${ }^{163}$.

O Código Civil alemão introduziu, também recentemente, o $§ 313$, abaixo transcrito e vertido para o italiano ${ }^{164}$ :

\begin{tabular}{|l|l|}
\hline \$13 Störung der Geschäftsgrundlage & \$13 Alterazione del fondamento negoziale \\
\hline (1) Haben sich Umstände, die zur Grundlage & (1) Se le circostanze che sono diventate il \\
des Vertrags geworden sind, nach & fondamento del contratto sono notevolmente \\
Vertragsschluss schwerwiegend verändert und & mutate dopo la conclusione del contratto, e le \\
hätten die Parteien den Vertrag nicht oder mit & parti non avrebbero concluso il contratto o lo \\
anderem Inhalt geschlossen, wenn sie diese & avrebbero concluso con un contenuto diverso se \\
Veränderung vorausgesehen hätten, so kann & avessero previsto questi mutamenti, può \\
Anpassung des Vertrags verlangt werden, & pretendersi l'adeguamento del contratto, \\
soweit einem Teil unter Berücksichtigung aller & qualora tenuto conto di tutte le circostanze del \\
Umstände des Einzelfalls, insbesondere der & caso concreto, in particolare della distribuzione \\
vertraglichen gesetzlichen & contrattuale e legale dei rischi, da una delle \\
Risikoverteilung, das Festhalten am & parti non possa pretendersi il mantenimento del \\
unveränderten Vertrag nicht zugemutet werden & contratto non modificato. \\
kann. & (2) Al mutamento delle circostanze è parificata \\
(2) Einer Veränderung der Umstände steht es & l'ipotesi in cui le rappresentazioni essenziali che \\
gleich, wenn wesentliche Vorstellungen, die & sono diventate fondamento del contratto si \\
zur Grundlage des Vertrags geworden sind, & rivelano false. \\
sich als falsch herausstellen. & (3) Se non è possibile un adeguamento del \\
(3) Ist eine Anpassung des Vertrags nicht & contratto o esso non sia pretendibile da una \\
möglich oder einem Teil nicht zumutbar, so & delle parti, la parte svantaggiata può recedere \\
kann der benachteiligte Teil vom Vertrag & dal contratto. Nei rapporti obbligatori di \\
zurücktreten. An die Stelle des Rücktrittsrechts & durata, al posto del diritto di recesso subentra il \\
tritt für Dauerschuldverhältnisse das Recht zur & diritto di disdetta. \\
Kündigung. &
\end{tabular}

O $\S 313$ do BGB trata da figura da revisão ou da resolução do contrato por onerosidade excessiva sob a denominação "Perturbação da Base do Negócio" (Störung der Geschäftsgrundlage).

O mencionado parágrafo foi introduzido no BGB quando da reforma do Direito Obrigacional no ano de 2001. O remédio da revisão do contrato pela alteração da base do negócio jurídico, no entanto, já é bem mais antigo, tendo sido extensivamente desenvolvido pela doutrina e jurisprudência alemãs, desde o Reichsgericht e,

\footnotetext{
${ }^{163}$ Sobre a distinção entre conceitos legais indeterminados e cláusulas gerais, vide Nery Jr., N. e Nery, R., Código Civil Comentado, São Paulo, Revista dos Tribunais, $4^{\mathrm{a}}$ ed., 2006, p. 162.

${ }^{164}$ BGB, § 313; Codice Civile Tedesco - Bürgerliches Gesetzbuch. Trad. Patti, S., Milão, Giuffré-Beck, 2005, pp. 186-189:
} 
posteriormente, pelo Bundesgerichtshof ${ }^{165}$, por autores como Windscheid (Teoria da Pressuposição) e Oertmann (Teoria da Base do Negócio Jurídico) e, mais recentemente, Karl Larenz. O desenvolvimento dessa jurisprudência pelo Reichsgericht foi uma resposta às graves dificuldades econômicas enfrentadas na Alemanha após a I Guerra Mundial. A jurisprudência teve de lidar com problemas relacionados à inflação e à desvalorização da moeda, que tiveram impacto significativo em muitos negócios, por exemplo, aqueles estabelecidos por longo prazo com preços fixos.

$\mathrm{O} \S 313$ do $\mathrm{BGB}$, remete - embora não incorpore totalmente - à teoria da base do negócio jurídico e tem como premissa que, quando da realização do negócio, as partes partem de certos pressupostos e têm certas expectativas, que, no entanto, não estão necessariamente contidas nas declarações de vontade expressas. A base do negócio, ou seus fundamentos, como se verá abaixo, equivale ao tratamento dado às “unforeseen contingecies" pela Análise Econômica do Direito. Como regra, a não realização dessas expectativas ou a incorreção de certas premissas não é razão suficiente para que se afete de qualquer modo o vínculo contratual, em face da máxima pacta sunt servanda. Contudo, existiriam situações excepcionais, nas quais não seria justo exigir o cumprimento do contratado, pois estaria diretamente afetada a própria base do negócio.

Note-se que essa avaliação de equidade permeia todo o remédio da quebra da base do negócio desenvolvido pela jurisprudência, que, anteriormente à introdução do $\S 313$ ao BGB utilizou como fundamento o $\S 242$ do mesmo código, que trata da prestação da obrigação segundo os padrões da boa-fé e das práticas comerciais.

O $§ 313$ do BGB prevê duas hipóteses de aplicação, mas como conseqüências jurídicas idênticas: modificação prejudicial de circunstâncias, que constituem a base do negócio, após a conclusão do mesmo; ou a revelação de falsidade de premissas, tidas como essenciais e que constituem a base do negócio, já desde o momento da celebração do contrato.

Existem diversos pontos em comum entre as hipóteses. Em primeiro lugar, há a necessidade de se identificar uma perturbação na base do negócio, que

\footnotetext{
${ }^{165}$ Larenz, K.; Base del Negocio Jurídico y Cumplimiento de los Contratos, Granada, Editorial Comares, 2002, pp. 5-27 (passim).
} 
será definida mais adiante. Além disso, entende-se que as partes não teriam concluído o contrato ou o teriam concluído com outro conteúdo, caso tivessem previsto a alteração de tais circunstâncias ou tivessem partido de premissas corretas. Chegando-se à conclusão contrária, de que a parte prejudicada pela alteração tivesse interesse o suficiente na realização do contrato, e o teria celebrado com o mesmo conteúdo mesmo sabendo da possibilidade de alteração posterior, não seria aplicável o $§ 313$ do BGB.

Por fim, para que sejam aplicáveis as disposições do $§ 313$ do BGB, deve-se atestar que o cumprimento de obrigações contratuais pelo devedor não pode ser razoavelmente exigido, em face de novas circunstâncias ou de verdadeiras condições, antes desconhecidas pelas partes. Essa avaliação da razoabilidade de se exigir o cumprimento da prestação deve levar em conta as circunstâncias do caso concreto, especialmente a repartição dos riscos contratuais, realizada pela lei ou pelas partes no próprio contrato.

A lei alemã, porém, não definiu o que seria a base do negócio em si, assim como os Códigos Civis brasileiro e italiano não definiram o que se entende por “acontecimento extraordinário". Na falta de definição legal de base do negócio, recorre-se à jurisprudência anterior do Bundesgerichtshof. De acordo com Dieter Schwab ${ }^{166}$, a jurisprudência define a base do negócio como: a) os pressupostos comuns às partes quando da conclusão do negócio, sem que eles tenham se convertido em conteúdo contratual, ou b) então os pressupostos de uma das partes que foram reconhecidos pela outra parte ou the eram reconhecíveis e por ele não refutados; c) sendo que em ambos os casos, a existência ou a realização futura de tais pressupostos são os fundamentos sobre os quais a vontade das partes se construiu. Portanto, as partes declaram sua vontade tendo, reconhecidamente, se baseado nestas premissas, que posteriormente não se verificam integralmente, afetando comprovadamente a capacidade de uma ou de ambas as partes de realizarem suas obrigações do modo contratado.

Além da distribuição contratual e legal de riscos, deve-se avaliar o grau de prejuízo a que se submeteria o devedor se cumprisse sua obrigação como inicialmente acordado. Se o prejuízo verificado se dá em grau previsível e típico, não tem lugar a aplicação do $\S 313$, pois todo contrato contém certo risco e cabe a cada um dos

${ }^{166}$ Schwab, D., Einführung in das Zivilrecht, Heidelberg, 16. Auflage, 2005, C.F. Müller, p. 289. 
contraentes cuidar da proteção de seus interesses, de modo a se resguardar de eventuais prejuízos. Assim, só cabe a aplicação do $\S 313$ se o prejuízo for extraordinário e desproporcional, sendo injusto que apenas esse um o suporte sozinho.

Finalmente, o BGB dispõe claramente sobre a possibilidade de alteração da alocação contratual de riscos no caso de revisão do contrato. Dessa maneira, a aplicação do $\S 313$ não se limita à revisão dos preços contratuais.

Como dito acima, os Estados Unidos, no começo do século, adotaram a doutrina das "implied conditions", especialmente as doutrinas da "frustration", impossibility" e "impracticability" do cumprimento do contrato, como remédio tendente à flexibilização do vínculo contratual. Essa doutrina foi incorporada ao Uniform Commercial Code-UCC $\boldsymbol{C}^{\mathbf{1 6 7}}$, que trata da compra e venda de mercadorias e também ao Restatement (Second) of Contracts. A redação do UCC menciona expressamente a alteração nos pressupostos do negócio, à semelhança do que faz o $§ 313$ do BGB, impondo a obrigação ao vendedor de mitigar as conseqüências danosas. Os $\S \S 261$ e 265 do Restatement (Second) of Contracts ${ }^{168}$, vão no mesmo sentido.

167 Uniform Commercial Code, artigo 2 (Sales), § 615

\$ 2-615. Excuse by Failure of Presupposed Conditions.

Except so far as a seller may have assumed a greater obligation and subject to the preceding section on substituted performance:

(a) Delay in delivery or non-delivery in whole or in part by a seller who complies with paragraphs (b) and (c) is not a breach of his duty under a contract for sale if performance as agreed has been made impracticable by the occurrence of a contingency the non-occurrence of which was a basic assumption on which the contract was made or by compliance in good faith with any applicable foreign or domestic governmental regulation or order whether or not it later proves to be invalid.

(b) Where the causes mentioned in paragraph (a) affect only a part of the seller's capacity to perform, he must allocate production and deliveries among his customers but may at his option include regular customers not then under contract as well as his own requirements for further manufacture. He may so allocate in any manner which is fair and reasonable.

(c) The seller must notify the buyer reasonably that there will be delay or nondelivery and, when allocation is required under paragraph (b), of the estimated quota thus made available for the buyer.

${ }^{168}$ Os Restatements of Contracts (há o primeiro e o segundo) não têm força de lei, mas são uma compilação da common law of contracts elaborada pelo American Law Institute, que serve como doutrina de grande peso para juízes e advogados estadunidenses (vide Calamari, J. e Perillo, cit., pp. 13-14). 
Vale notar que o Uniform Commercial Code não é legislação federal dos EUA, mas sim um modelo de lei uniforme elaborado conjuntamente pelo American Law Institute e National Conference of Commissioners on Uniform State Laws, porém adotado como lei estadual por todos os estados daquele país, inclusive Distrito Federal, com pequenas alterações, no exercício de suas respectivas jurisdições ${ }^{169}$.

O breve apanhado do tratamento dado à superveniência contratual em alguns dos países "revisionistas" de maior economia entre os países desenvolvidos, mostra tendência evidente à ampliação das hipóteses de abertura de possibilidade de revisão do contrato. Com efeito, Itália e Brasil ainda restringem a revisão contratual por onerosidade excessiva à superveniência de "acontecimentos imprevisíveis e extraordinários", enquanto as doutrinas adotadas na Alemanha e EUA conferem maior peso à relevância para as partes contratantes da pressuposição ou circunstância que veio a não se confirmar. Os elementos de imprevisibilidade e extraordinariedade da alteração do "ambiente objetivo existente no tempo da formação do contrato", nas palavras de Medeiros da Fonseca ${ }^{170}$.

\subsubsection{Intervenção do juiz na relação contratual}

Como já dito anteriormente, o artigo $479^{171}$ do Código Civil expressamente prevê a possibilidade de renegociação do contrato em termos "eqüitativos". Esse artigo traz uma nova dinâmica ao ordenamento, na medida em que, proposta a ação de resolução contratual, abrem-se ao réu três possibilidades:

1. contestar o pedido, alegando que não ocorrem os pressupostos da caracterização da onerosidade excessiva, quais sejam: a) existência de prestação diferida no tempo; b) que a prestação não tenha sido paga ou, de qualquer maneira, considerada indevida

\footnotetext{
${ }^{169}$ Calamari, J. e Perillo, J., The Law of Contracts, Saint Paul, West Publishing Co., $3^{\mathrm{a}}$ ed., 1987, p. 15.

${ }^{170}$ Medeiros da Fonseca, A., op. cit. p. 346.

${ }^{171}$ Art. 479. A resolução poderá ser evitada, oferecendo-se o réu a modificar eqüitativamente as condições do contrato.
} 
por outras razões; c) que a onerosidade seja excessiva e; d) que efetivamente tenha se verificado o acontecimento "imprevisível e extraordinário"172;

2. nos termos do artigo 479 , formular proposta que preveja a modificação eqüitativa do contrato; e

3. c) confessar o pedido.

Caso o réu não apresente proposta conforme o item 2, acima, e sua contestação seja acolhida, finda-se o processo com derrota do autor, devendo o contrato ser cumprido como originalmente pactuado. Ao contrário, caso a o réu confesse o pedido ou sua contestação não seja acolhida, sem que tenha apresentada proposta de reformulação das condições do contrato, o juiz declarará resolvido o contrato, com o conseqüente rompimento do vínculo contratual (ou, se aplicado o artigo 317 do Código Civil conforme interpretação abaixo descrita, pode "corrigir" o valor da prestação).

No entanto, caso o réu apresente em juízo proposta de modificação do contrato e esta não seja aceita pelo autor da ação (ou as partes entrem em tratativas para renegociação do contrato), levanta-se questão que tem dividido a doutrina. A questão que se põe é de qual seria o âmbito do poder do juiz: se a prestação jurisdicional deveria ficar limitada à apreciação do caráter eqüitativo ou não da proposta formulada pelo réu, ou se deveria ir além, se o juiz teria o poder de alterar os termos da proposta conforme considere se amoldar a seu juízo de eqüidade.

Nesse sentido, a preservação de relações jurídicas estabelecidas que tenham chegado a ponto de rompimento tende, do ponto de vista do Direito Comparado, a levar à interferência do juiz na relação ${ }^{173}$. No Brasil e na Itália, duas posições se entrechocam: de um lado, em decorrência do princípio da autonomia da vontade, há os que não admitam a interferência do juiz na relação contratual além do julgamento sobre se a proposta formulada em termos eqüitativos ou não. Outros há que a $\operatorname{admitam}^{174} \mathrm{e}$

\footnotetext{
${ }^{172}$ Roppo, V,. Il Contrato, p. 1017.

${ }^{173}$ Como visto acima, essa interferência foi historicamente rechaçada na França e mesmo nos Estados Unidos - ide nota $\mathrm{n}^{\circ} 40$, acima e também Grynbaum, Luc; Le contrat Contingent - L'Adaptation du Contrat par le Juge sur habilitation du Législateur, L.G.D.J. Paris, 2004, pp. 25-81

${ }^{174}$ Inclusive no direito norte-americano moderno, sendo que Luc Grynbaum chega a ver na evolução do Direito Arbitral um fator de interferência de terceiros sobre o regulamento contratual [Grynbaum, L. ; op. cit. p. 124].
} 
consideram que ao juiz, efetivamente, é conferido o poder de alterar a proposta formulada pelo réu para reduzi-la ao que entenda ser eqüitativo ${ }^{175}$, em vista do direito potestativo do réu de lançar mão da proposta como instrumento de recomposição da alocação de riscos e responsabilidades do contrato.

De fato, não parece que o artigo 479 do Código Civil restrinja seu campo de atuação ao mero juízo de verificação da eqüidade da proposta. O ânimo de prosseguimento na relação contratual demonstra que o contrato pode ser viável, ou seja, que existe espaço para o alcance de uma solução eqüitativa, que pode ser suprida pelo juiz mediante os meios de prova necessários. Em outras palavras, embora as implicações econômicas desse entendimento não sejam necessariamente positivas, o artigo 479, por si só já autorizaria a revisão da proposta apresentada pelo réu, para fins de conservação e continuidade da relação contratual ${ }^{176}$.

Entretanto, não bastasse o artigo 479, o artigo $317^{177}$ do Código Civil parece mais claramente permitir ao juiz, ele próprio, ser um agente de renegociação, aplicando-se aqui, perfeitamente, a tese de Kojève, citado por Luc Grynbaum ${ }^{178}$, segundo a qual "a essência do direito se realiza e se revela (ou se manifesta) na e pela interação entre dois seres humanos, A e B, que provocam, necessariamente, a intervenção de um terceiro

175 Na Itália, Martino reporta que a jurisprudência da Corte de Cassação é divida a respeito. Vide Martino V,. La risoluzione per eccessiva onerosità: in I Contratti in Generale, coleção Il Diritto Privato Nella Giurisprudenza - a cura de Cendon, P. - vol. XIII, Turim, UTET, 2000, pp. 580-581.

${ }^{176}$ Vide, a esse respeito, Martins-Costa, Judith, A Revisão dos Contratos no Código Civil Brasileiro: "Na revisão prevista no art. 317 há poder formativo modificativo, que será exercido pelas partes, mediante negociação, ou por intermédio do juiz. Esse poder formativo modificativo nasce da desproporção que atinge a prestação. A sentença retroage ao momento da desproporção, caso o pagamento tenha sido parcelado e pagamentos anteriores tenham ocorrido. Conquanto a dicção legal verse 'o' pagamento, parecendo destinarse unicamente a prestações únicas e diferidas (caso em que a sentença terá eficácia para o pagamento a ser feito, isto é, ex nunc), nada impede que estendamos a aplicação do art. 317 para os contratos duradouros, com prestações sucessivas." ( trabalho apresentado nas XIX Jornadas Nacionales de Derecho Civil, Rosario, Argentina, 25 a 27 de setembro de 2003, disponível em http://200.61.186.245/civil/MartinsCosta\%20(Com.3).pdf:

${ }^{177}$ Art. 317. Quando, por motivos imprevisíveis, sobrevier desproporção manifesta entre o valor da prestação devida e o do momento de sua execução, poderá o juiz corrigi-lo, a pedido da parte, de modo que assegure, quanto possível, o valor real da prestação.

${ }^{178}$ Grynbaum, L.; Le Contrat Contingent - L'Adaptation du Contrat par le Juge Sur Habilitation du Législateur, Paris, L.G.D.J., 2004, p. 23 
imparcial e desinteressado C" (tradução nossa). Parece ainda mais evidente que, caso o réu na ação de resolução do contrato por onerosidade excessiva não ofereça proposta de renegociação em termos que o juiz considere eqüitativos (ou seja, à primeira vista, por eqüitativo entender-se-ia a divisão dos ônus e perdas), ele mesmo, juiz, poderia corrigir o valor da prestação de modo a preservar o contrato.

Essa possibilidade parece aberta, no Brasil, com o advento do artigo 317 do vigente Código Civil, que prevê ser dado ao juiz o poder de "corrigir" a desproporção manifesta entre o valor da prestação devida e o do momento de sua execução. Esse artigo, se combinado com o artigo 479, pode levar à interpretação de que, uma vez oferecida a modificação eqüitativa das condições do contrato, estaria confirmado que o juiz poderia ter o poder de adotar essas novas condições como as prevalentes entre as partes. Ou seja, ao juiz seria o dado o poder de rever o contrato, suprindo o acordo das partes.

No entanto, embora os poderes conferidos ao juiz pelo artigo 479 sejam mais amplos diante do oferecimento da proposta pelo réu (pois o magistrado poderá alterar todas as condições da proposta que, a seu juízo, não pareçam eqüitativas, inclusive as que digam respeito à alocação dos riscos) em relação ao artigo 317, seus poderes são, de um lado, mais incisivos, e, de outro, menos amplos. Mais incisivos porque, caso o autor da ação fundamente o pedido de revisão com base no artigo 317, o juiz poderia rever o valor da prestação ainda que o réu não se dispusesse a oferecer a proposta modificativa do contrato. Por outro lado, esses poderes seriam menos amplos que os conferidos pelo artigo 479, pois, aplicando o artigo 317, ao juiz caberia apenas rever o valor da prestação - e não a alocação global de riscos do contrato ${ }^{179}$.

Ainda que, para alguns, o locus materiae do artigo 317 o desqualifique como dispositivo autorizador da revisão do valor da prestação em qualquer caso de evidenciação da onerosidade excessiva, não se pode colocar em questão que, se

\footnotetext{
${ }^{179}$ Contra essa tese, vide Leães, L.; A Onerosidade Excessiva no Código Civil, Revista de Direito Bancário e do Mercado de Capitais, vol. 31, ano 9, jan-mar de 2006, pp. 19-20. A favor Martins-Costa, J, A Revisão dos Contratos no Código Civil Brasileiro; trabalho apresentado nas XIX Jornadas Nacionales de Derecho Civil, Rosario, Argentina, 25 a 27 de setembro de 2003, disponível em http://200.61.186.245/civil/MartinsCosta\%20(Com.3).pdf: , consultado em 10.03.2006. Vide também, da mesma autora, Comentários ao Código Civil, vol. V, Tomo I. Rio de Janeiro, Forense, 2003, p. 257.
} 
admitida a eficácia combinada dos artigos 317 e 479 do Código Civil, ampliar-se-ia consideravelmente o poder judicial de revisão dos contratos.

Como visto, o novo Código Civil, portanto, introduziu no ordenamento jurídico brasileiro nova dinâmica negocial que, para efeitos deste trabalho demonstra que vínculo contratual passa a ser cada vez mais flexível e sujeito a considerações outras que não somente as atinentes à operação econômica subjacente ao contrato. 


\subsection{A ALOCAÇÃO CONTRATUAL DE RISCOS}

Uma das principais maneiras pelas quais se concretiza juridicamente a alocação de riscos desejada pelas partes contratantes é o próprio regime de preços adotado. Em contratos empresariais que seguem o modelo estudado neste trabalho, o regime de preços costuma assumir uma de três formas usuais: preço global ou fixo, preço por administração e preço por unidades de medida ${ }^{180}$.

Designa-se preço global aquele cujo valor é integralmente prédefinido pelas partes contratantes de maneira a independer da variação dos custos efetivos dos insumos empregados no empreendimento cuja realização seja objeto da contratação. A qualificação "global" decorre da circunstância de o valor do preço compreender todos os custos necessários à execução do objeto contratual, inclusive lucros da contratada. A qualificação "fixo", às vezes utilizada, pode ser confundida, no Brasil, com o caráter irreajustável do preço, porém designa, mais precisamente, a circunstância de o preço não poder variar em função dos custos efetivamente suportados pela contratada. Cláusula típica desse modelo encontra, em formulários editados pela FIDIC $^{181}$, a seguinte redação:

\subsection{Sufficiency of the Contract Price}

The Contractor shall be deemed to have satisfied himself as to the correctness and sufficiency of the Contract Price.

Unless otherwise stated in the Contract, the Contract Price covers all the Contractor's obligations under the Contract (including those under Provisional Sums, if any) and all things necessary for the proper design, execution and completion of the Works and the remedying of any defects.

Designa-se preço por administração, em contraste, aquele cujo valor varia, em grande parte, em função dos custos efetivos do empreendimento de que se trata. Sua configuração básica é identificada segundo dois elementos: a variação do custo dos insumos utilizados e uma "taxa de administração" (fee), usualmente estabelecida como um percentual dos custos efetivos ${ }^{182}$.

\footnotetext{
${ }^{180}$ Para uma análise simplificada, vide Shavell, Steven et alli, Analytical Methods for Lawyers, Foundation Press, 2003, seção sobre "production contracts", pp. 74 a 88.

${ }^{181}$ Conditions of Contract for EPC/Turnekey Projects, Genebra, FIDIC, $1^{\text {a }}$ ed. 1999, p. 14.

${ }^{182}$ É também comum, no jargão do setor, referir-se a essa taxa de administração como "BDI - Bonificações (ou Benefícios) e Despesas Indiretas" e geralmente compreende o valor estimado dos riscos residuais do empreiteiro, as despesas financeiras, as taxas de negociação e, finalmente, a bonificação ou lucro.
} 
E, ainda, designa-se preço por unidade de medida uma combinação das categorias acima: ainda que o preço final seja variável, a variação é calculada a partir de medidas cuja importância já compreende os custos e o lucro da contratada. Um exemplo típico é a contratação de determinado serviço (como a elaboração de projeto de engenharia) segundo uma tarifa horária. Uma vez somadas as horas despendidas, o valor final está dado, não havendo acréscimo de lucro.

Para fins de análise, de maneira a extremar as conseqüências que engendram situações de mudança superveniente de circunstâncias relevantes do negócio, consideraremos, a seguir, apenas os dois primeiros regimes: preço global e por administração.

Suponha-se, para fins de ilustração e concretude, que se trata de um contrato para construção de usina hidrelétrica. Em tais contratos, o escopo completo pode abranger o suprimento de equipamentos (notadamente, turbinas e geradores e sistemas de transmissão), materiais (notadamente, cimento, ferro, alumínio e cabos) e execução de serviços (notadamente, projeto de engenharia, construção, montagem e testes).

De início, importa notar que não é possível determinar, em abstrato, qual regime de preços é o mais vantajoso para execução do contrato, ainda que se cogite apenas do interesse do dono da obra. Isso porque o risco de flutuação do custo dos insumos não é, a rigor, eliminado por qualquer um deles. Ainda que, aparentemente, o contrato por administração deixe essa flutuação explícita, a assunção do risco de flutuação pelo empreiteiro, no contrato a preço global, costuma ser acompanhada do acréscimo de um sobrevalor (na prática empresarial designado, sem grande precisão terminológica, contingência, provisão ou margem) correspondente a uma avaliação da probabilidade de variação futura e do montante que essa variação atingiria. De fato: "Contractors, upon receiving a bid request, evaluate the cost of building the project, and will, consciously or not, add contingencies for risks. If contingencies were not added, contractors could quickly go out of business." "183

\footnotetext{
${ }^{183}$ Hartman, Francis; Snelgrove, Patrick, Risk Allocation in Lump-Sum Contracts - Concept of a Latent Dispute”Journal of Construction, Engineering and Management, September 1996, p. 291.
} 
Em outras palavras ${ }^{184}$ :

\begin{abstract}
Many employers [donos de obra] take the view that their interests are best served by transfering as much risk to the contractor as possible, perceiving that they [os donos da obra] can be benefited by maintaining a risk-free position. However, this is not always right. It is inevitable that for every risk shifted from one contract party to another, there arises a financial adjustment. When contractors account for contingencies in their tender price for a risk shift, employers would need to pay for the risk whether it is materialized or not.
\end{abstract}

Desse modo, somente uma comparação de tal sobrevalor com o custo a ser suportado pelo dono da obra, no contrato por administração (relativo à sua qualificação e estrutura específicas para controle da execução da obra de determinado projeto) poderia permitir a determinação de qual regime é mais vantajoso ${ }^{185}$. Em termos simplificados, o efeito da escolha do regime de preços, nesse caso, seria a transferência, de uma parte à outra, do risco representado pela flutuação do custo dos insumos, transferência, essa, no entanto, que também é, por si, suscetível de avaliação econômico-financeira quer dizer, também representa custo.

Com efeito, a contratação de uma obra do tipo descrito acima, sob regime de preço global e do ponto de vista do dono da obra, pode ser descrita

\footnotetext{
${ }^{184}$ Yau, Maria; Chan, Edwin, Attitudes of Contractors and Employers Towards Transfer of a Time-Related Risk in Construction Contracts, [American Society of Civil Engineers - ASCE - Construction Research Congress, 2005, Broadening Perspectives, Proceedings of the Construction Research Congress 2005 held in San Diego, California, April 5-7, 2005 - doi: 10.1061/40754(183)68 http://ascelibrary.aip.org $/ \mathrm{dbt} / \mathrm{dbt}$.jsp?KEY $=$ ASCECP $\&$ Volume $=183 \& I$ ssue $=40754 \&$ bproc $=$ year \&scode $=200$ $5 \&$ confTitle $=$ Construction + Research + Congress +2005 - consultado em 23.10.2006].
}

${ }^{185}$ Ressalte-se, ainda que brevemente, que, quando a incerteza de que se trata diz respeito não apenas aos custos, mas à própria caracterização do objeto cuja produção ou execução constitui o fim da contratação, regimes de preço global, segundo recente estudo empírico $(*)$, tendem a ser menos onerosos ao empreendedor/dono do negócio. No caso de uma usina hidrelétrica, uma vez que a viabilidade do empreendimento tenha sido analisada, é possível fixar de antemão o parâmetro objetivo de desempenho: a potência que se espera seja gerada, por exemplo (há outros parâmetros, como índice de vazão, mas que também são determináveis segundo um critério pré-fixado). Nesse caso, o principal elemento de incerteza, do ponto de vista analítico, é o custo e as questões que dele resultam já são consideráveis. No entanto, se se trata de objeto cuja especificação (ou cujo parâmetro objetivo de desempenho) não é dada de antemão e cujos critérios de aferição não sejam facilmente observáveis - por exemplo, serviços contínuos de manutenção de determinada rodovia ou de transporte pública, cuja demanda pode variar significativamente ao longo do tempo - um novo elemento se integra, que aumenta consideravelmente a complexidade do modelo.

(*) Jensen, P. e Stonecash, R.; Contract Efficiency in the Presence of Demand and Cost Uncertainty, Melbourne Institute Working Paper $N^{\circ} 1 / 05$, The university of Melbourne, Janeiro 2005, ISSN 1447-5863 (online), ISN 07340 31777, http://www.melbourneinstitute.com/wp/wp2005n01.pdf - consultado em 2./10.2006. 
ilustrativamente como a compra de uma apólice de seguro (para garantir que os efeitos de eventual acréscimo do custo dos insumos não lhe afetará) - em que o prêmio seria o sobrevalor cobrado pelo empreiteiro. Ilustração da mesma natureza seria imaginar que o dono da obra, na empreitada a preço global "compra" um contrato futuro que teria por objeto o preço da obra. Como ocorreria se o valor da obra fosse referência de um contrato futuro, se o preço dos insumos aumentarem, o dono da obra estará "in the money". Se se mantiverem estáveis, ou caso se reduzam, ganhará o vendedor, ou o empreiteiro.

De fato, no transcurso da execução contratual, que normalmente se dilata no tempo, podem se revelar situações que potencialmente subverteriam o efeito do seguro comprado. De fato, uma das premissas da contratação a preço global é o pressuposto de inalterabilidade relevante da situação inicial. Isto porque, ao contrário de seguradoras e mercados de derivativos, os contratos de engineering não são de massa, como já demonstrado acima, não havendo grande diversificação do risco de encarecimento da obra ${ }^{186}$.

Por exemplo, suponha-se que o dono da obra deseje introduzir, por sua conveniência, uma mudança significativa no projeto de engenharia original - para ele, por hipótese, seria mais vantajoso que determinada via de acesso à obra fosse construída segundo trajeto diverso do previsto, que implicasse uma redução de custos de execução da obra. Deixando-se de lado considerações de má-fé, a contratação da obra a preço global, com efeito, permite ao empreiteiro obstar a alteração pretendida pelo dono da obra, ainda que sua cooperação pudesse resultar em situação considerada economicamente eficiente. Não se trata, evidentemente, de simples capricho do empreiteiro ou de possibilidade de recusa física de executar a obra. Trata-se de uma consideração jurídica: o empreiteiro estaria juridicamente autorizado a exigir o cumprimento da avença contratada, podendo, portanto, consentir ou não à sua alteração.

Para ilustração, o modelo uniforme da FIDIC $^{187-188}$ para contratos EPC/Turnkey concede ao dono da obra o direito de alterar o projeto, desde que o empreiteiro não se oponha de maneira justificada:

\footnotetext{
${ }^{186}$ Situação internacionalmente conhecida pela expressão inglesa "cost overrun".

${ }^{187}$ Conditions of Contract for EPC/Turnkey Projects, Genebra, FIDIC, $1^{\text {a }}$ ed. 1999, p. 34.
} 


\begin{abstract}
13.1 Right to Vary
Variations may be initiated by the Employer at any time prior to issuing the Taking-Over Certificate for the Works, either by an instruction or by a request for the Contractor to submit a proposal. A Variation shall not comprise the omission of any work which is to be carried out by others.

The Contractor shall execute and be bound by each Variation, unless the Contractor promptly gives notice to the Employer stating (with supporting particulars) that (i) the Contractor cannot readily obtain the Goods required for the Variation, (ii) it will reduce the safety or suitability of the Works, or (iii) it will have an adverse impact on the achievement of the Performance Guarantees. Upon receiving this notice, the Employer shall cancel, confirm or vary the instruction.
\end{abstract}

Na literatura de Law \& Economics, designa-se essa situação com a expressão hold-up problem $^{189}$ : aquela em que uma das partes pode deixar de cooperar com

${ }^{188}$ O modelo de Condições Gerais de Contrato de Construção do do A.I.A. - [Document A201-1997 General Conditions of the Contract for Construction] exige, expressamente, o acordo do construtor:

\title{
ARTICLE 7 CHANGES IN THE WORK
}

$\S 7.1$ GENERAL

\$7.1.1 Changes in the Work may be accomplished after execution of the Contract, and without invalidating the Contract, by Change Order, Construction Change Directive or order for a minor change in the Work, subject to the limitations stated in this Article 7 and elsewhere in the Contract Documents.

\$7.1.2 A Change Order shall be based upon agreement among the Owner, Contractor and Architect; a Construction Change Directive requires agreement by the Owner and Architect and may or may not be agreed to by the Contractor; an order for a minor change in the Work may be issued by the Architect alone.

\$ 7.1.3 Changes in the Work shall be performed under applicable provisions of the Contract Documents, and the Contractor shall proceed promptly, unless otherwise provided in the Change Order, Construction Change Directive or order for a minor change in the Work.

${ }^{189}$ Klein, B. verbete Hold-up Problem, The New Palgrave Dictionary of Economics and the Law, Palgrave Macmillan, 2002, vol. 2, p. 243. Klein exemplifica a noção da seguinte maneira:

Hold-up problem. The essential elements of 'the hold-up problem' can be illustrated with the following example. A builder constructs a house on land he does not own, but only leases short term. Perhaps the builder believes he has an understanding with the landowner on the future purchase price of the land. However, after the initial land lease expires, the landowner violates the intent of the contractual understanding by threatening to raise the land rent unless the builder agrees to buy the land at an exorbitant price. This simple example illuminates the three factors necessary for the occurrence of a hold-up.

A seguir, com base no exemplo acima, o Autor esclarece que os três fatores mencionados são os seguintes: 1) o investimento do construtor (builder) precisa ser específico para o terreno citado no exemplo; 2) o contrato que rege a relação entre construtor e dono do terreno é incompleto; 3) o dono do terreno precisa considerar proveitoso provocar a situação de hold-up. O Autor (p. 244), ainda referindo-se ao exemplo acima, considera que a situação exemplificada pode não ser satisfatória para explicar o problema do hold-up porque se baseia na ingenuidade do construtor. Williamson, O. E. [verbete Opportunistic Behavior in Contracts, The New Palgrave Dictionary of Economics and the Law, Palgrave Macmillan, 2002, vol. 2, p. 704] no entanto, levanta argumento decisivo, aos mencionar que: 
outra, obstaculizando ou impedindo (holding-up) a consecução de determinado ato em razão de sua posição favorável de barganha ou comportamento oportunista ${ }^{190}$, mesmo que tal ato tivesse como resultado uma situação Pareto-ótima ${ }^{191}$.

Por outro lado, se o empreiteiro, na comparação acima, "vende uma apólice de seguro" ao aceitar a contratação sob o regime de preço global, também estará sujeito às vicissitudes de ser "segurador". Estará sujeito também ao comportamento oportunista do dono, especialmente a situação de moral hazard ${ }^{192}$. Imagine-se, por exemplo, que um contrato hipotético tenha especificado que certa tecnologia, desenvolvida pelo dono da obra, deveria ser utilizada em certa planta industrial e que, em troco de dado

\begin{abstract}
The world of contract in the absence of opportunism is uninteresting: all contracts become self-enforcing by asking the parties to behave responsibly throughout. Yet opportunism does not, by itself, pose a serious contracting problem. For that is further necessary that contracts be incomplete (by reason of bounded rationality) and that the transaction possess attributes for which classical market contracting is poorly suited..
\end{abstract}

190 Ver, ainda, do ponto de vista negocial, Shavell, S. et alli, Analytical Methods for Lawyers, Foundation Press, 2003, p. 80 .

${ }^{191}$ Feldman, A.; verbete Pareto Optimality, The New Palgrave Dictionary of Economics and the Law, Palgrave Macmillan, 2002, vol. 3, p. 6; assim define a situação de Ótimo de Pareto:

The maximum welfare for the collectivity, or what Pareto calls maximum ophelimity, is a point 'from which it is impossible to move a very small distance, in such a way that the ophelimities of the individuals, except for some which remain constant, all increase ... '([1906] 1971: 452). In other words, it is a point from which no move can be made that would increase the welfare of some individuals and make no one worse off. This is the notion that is now known as Pareto optimality. (Note, however, that Pareto's own maximum ophelimity notion is defined locally 'impossible to move a very small distance ... ' - whereas the modern usage makes Pareto optimality a global criterion, with no 'small distance' restriction.)

${ }^{192}$ Moral hazard pode ser definido como:

[...] actions of economic agents in maximizing their own utility to the detriment of others, in situations where they do not bear the full consequences or, equivalently, do not enjoy the full benefits of their actions due to uncertainly and incomplete or restricted contracts which prevent the assignment of full damages (benefits) to the agent responsible. It is immediately apparent that this definition includes a wide variety of externalities, and thus may lead to nonexistence of equilibria or to inefficiencies of equilibria when they exist.

It is a special form of incompleteness of contracts which creates the conflict between the agent's utility and that of others. Such incompleteness may arise due to several reasons: the coexistence of unequal information and risk aversion or joint production, costs and legal barriers to contracting and costs of contract enforcement.

Kotowitz, Y.; verbete Moral Hazard, The New Palgrave: A Dictionary of Economics, The Macmillan Press Ltd., 1991 (reimpressão de 1996), vol. 3, p. 549. 
acréscimo de preço, o empreiteiro houvesse se obrigado a entregar a obra pronta para operação, uma vez que se informou sobre a tecnologia. No entanto, o dono da obra possuía mais informações sobre a probabilidade de ocorrência de falhas na tecnologia e, de maneira oportunista, pode ter se aproveitado da assimetria de informação entre ele e empreiteiro.

Em suma, o regime de contratação por preço global oferece ao dono da obra uma espécie de seguro, desde que as premissas iniciais (que não estejam sob controle do empreiteiro) não sejam alteradas de maneira relevante a ponto de haver desequilíbrio entre prestações e contraprestações. Note-se, como demonstrado acima, que ambas as partes no contrato estarão sujeitas a vicissitudes e comportamentos oportunistas. O contrato a preço global, à semelhança do contrato de compra e venda, embute conflito de interesses entre o empreiteiro, que deseja "vender" a obra com o maior lucro possível, e o dono da obra, em posição contrária, desejando pagar o menor preço possível. À diferença da compra e venda instantânea, no entanto, o contrato é de longa duração e abre-se a possibilidade de surgimento de contingências, decorrentes de comportamentos oportunistas ou não,

Como ocorre nos contratos de franquia, mais extensamente estudados no Brasil $^{193}$, contratos de engineering, aproveitando menção que a respeito dos primeiros faz Paulo Furquim de Azevedo ${ }^{194}$, sob a ótica da teoria dos jogos, são contratos que "apresentam esse mesmo problema de descolamento entre a decisão individual e o desejável entre duas ou mais partes".

Contratos de engineering tipicamente vivem o dilema da cooperação versus o interesse individual, dada a continuidade no tempo da relação contratual e a circunstância de que o pagamento do preço inicialmente fixado em contrato não constitui o único dever do dono da obra do ponto de vista da execução ótima do contrato. No exemplo acima, caso o dono da obra não proceda ao reequilíbrio contratual dado o súbito aumento de preços de certa matéria prima, abre-se campo para comportamentos que fogem ao melhor interesse

\footnotetext{
${ }^{193}$ Vide Azevedo, P. F. e Silva, V. L. S., Contractual mix in Brazilian Franchising, Fifth Conference of the International Society for the New Institutional Economics, Setembro, 2001, apud Zylbersztajn, D. e Sztajn, R, Direito \& Economia, Campus - Elsevier, São Paulo, 2005, p.133.

${ }^{194}$ Zylbersztajn, D. e Sztajn, R, Direito \& Economia, Campus - Elsevier, São Paulo, 2005, p.116.
} 
deste último na medida em que o empreiteiro tenderá a reduzir custos de outros itens envolvidos na construção, redução essa que pode não atender ao interesse do dono da obra.

Ao mesmo tempo que interessa ao empreiteiro a redução de custos globais, com conseqüente aumento da margem de lucros, para o dono da obra, redução de custos pode representar decréscimo de qualidade, com reflexos na utilidade que pretendia extrair da obra, a posteriori. Se fica claro que nem sempre atende ao melhor interesse do dono da obra pagar o menor preço, ao empreiteiro também nem sempre interessa a redução de custos em prejuízo da qualidade final da obra, visto que eventuais garantias contratuais podem gerar demandas por reparos custosos e o dano à reputação do empreiteiro pela má consecução da obra de grande porte é facilmente verificável por outros possíveis clientes.

Para que se assegure o cumprimento contratual a contento, as minutas contratuais frequentemente prevêem cláusulas de fiscalização da obra pelo dono ou por terceiros de sua indicação (os chamados owner's engineers ou engenheiros de fiscalização); garantias contratuais e penalidades. Do lado do engenheiro, o cumprimento perfeito e pontual de suas obrigações algumas vezes enseja o pagamento de prêmios, como ocorre, por exemplo, em usinas termelétricas, quando a obra, em sua conclusão, tem eficiência energética igual ou maior que a prevista em contrato.

Se o regime de preço é por administração, por outro lado, a premissa da inalterabilidade da situação inicial é aliviada - o novo projeto de via de acesso terá sua repercussão em termos de preço naturalmente decorrente da variação dos custos do novo trajeto e o empreiteiro não pode, em princípio, opor-se a ela.

A conclusão acima, no entanto, além de presumir uma configuração bastante básica dos regimes de preço - por exemplo, as partes contratantes podem criar situações intermediárias, definindo limites máximos e mínimos para a taxa de administração, independentemente da variação efetiva dos custos ${ }^{195}$ - baseou-se em hipótese em que a responsabilidade pela alteração da situação inicial foi, claramente,

\footnotetext{
${ }^{195}$ Por exemplo, "[t] he use of targets - such as schedule targets or total cost - to provide incentives in cost reimbursable contracts is believed to be a valid and practical approach towards overcoming their inherent weaknesses." Ver, para este e outros exemplos, Bower, D.; Ashby, G.; Gerald, K.; Smyk, W., "Incentives Mechanisms for Project Success", Journal of Management in Engineering, Vol. 18, No. 1, 2002.
} 
atribuída ao dono da obra. Cumpre cogitar, no entanto, de hipótese diversa, em que a responsabilidade pela alteração não fosse tão diretamente atribuível a qualquer das partes.

Suponha-se que, após o início dos trabalhos de construção, sobreviesse legislação referente à segurança do trabalho, que impusesse, ao executor da obra, o emprego de equipamentos de proteção aos seus trabalhadores cujo custo seria significativamente superior ao originalmente considerado. Se se admite, por hipótese, que o risco da mudança na legislação seja do dono da obra, a conclusão anteriormente enunciada - a possibilidade de caracterização de hold-up problem - se mantém. Se se entende, por outro lado, que a contratação de execução de uma obra por preço global importa, explícita ou, mais importante, tacitamente, a assunção do risco de variação de quaisquer custos, inclusive daqueles resultantes de mudança na legislação, ao empreiteiro, este deixará de estar legitimado (desde o ponto de vista jurídico, note-se, novamente) a se recusar a prosseguir a execução.

Ainda explorando o tema da edição de norma legal como evento externo influente sobre a vida do contrato - já que esse tipo de evento é passível de contratação de seguro apenas em raras hipóteses - caso inexistente previsão contratual, a quem alocar o risco da obtenção de licenças de funcionamento providas por autoridades estatais que não estejam adstritas a prazos ou autoridades que possam exercer certa discricionariedade? Pense-se em certa construção de unidade industrial que empregasse tecnologia de terceiros sujeita a prévia aprovação por Decreto e que certa parte do preço estivesse vinculada à entrada em funcionamento da unidade. Como a unidade não pode entrar em operação enquanto não expedido o ato regulamentar, a quem caberia arcar com os custos do atraso no funcionamento? A empreiteira deveria ser paga em dia, ou o dono da obra poderia se eximir do pagamento (inclusive eventuais acréscimos) até que o Decreto fosse expedido? Em muitas circunstâncias, o dono da obra seria o superior risk bearer, na terminologia empregada por Posner ${ }^{196}$, uma vez que poderia converter a unidade para industrialização de outros produtos, não sujeitos a licenças, ou então poderia ter obtido a licença mesmo antes da contratação do empreiteiro, por exemplo.

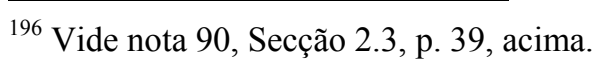


Por outro lado, casos há em que o empreiteiro está em melhor posição para assumir riscos advindos de eventual regra legal que altere o ambiente de execução contratual. No exemplo anterior, se a tecnologia de produção é também provida pelo empreiteiro, fica patente que este está em vantagem para a administração do risco. Ocorre que, voltado à distinção de Posner entre prevenção e seguro, o contrato pode ter explicitamente previsto que o empreiteiro arcasse com o risco de edição do Decreto de aprovação de uso da tecnologia, muito embora não fosse o detentor do conhecimento tecnológico específico. Nesse caso, o dono da obra deliberadamente transferiu o risco ao empreiteiro, como um assegurado transfere certo risco a uma seguradora.

Voltando, uma vez mais a Posner, a noção de superioridade técnica para suportar riscos, no engineering, não é tão óbvia, uma vez que, como visto na citação acima, os projetos possuem grande variância, o que, por si só, significa risco. Essa variância, como visto em capítulo anterior, explica-se pela complexidade dos projetos e obras de engenharia.

Cabe referir que a própria identificação de determinada cláusula como atribuindo um risco a um dos dois pólos da relação contratual não é necessariamente fácil, entre outros fatores, pela grande variação dos riscos inerentes a cada projeto, como visto acima. Ao contrário, estudo empírico recente ${ }^{197}$ sugere que donos de obras, empreiteiros e consultores externos (mesmo em situação em que não são parte na relação concreta, mas analisam a redação de determinado conjunto de cláusulas-padrão largamente utilizado em determinada indústria) divergem significativamente quanto à interpretação das mesmas cláusulas contratuais. É evidente que, nas palavras dos autores do estudo, "[i]n terms of mutual understanding of risk apportionment, it is desirable to have all three parties interpret risk allocation in the same way". Ocorre que, segundo os resultados obtidos, esse não é o caso. As mesmas cláusulas sobre alterações do escopo dos serviços, condições de solo e subsolo, conseqüências de atrasos às obras causados por autoridades públicas, relação com outras empresas contratadas pelo dono da obra, quando analisadas por um dos pólos, são entendidas de maneiras diferentes.

\footnotetext{
${ }^{197}$ Hartman, Francis; Snelgrove, Patrick, Risk Allocation in Lump-Sum Contracts - Concept of a Latent Dispute, Journal of Construction, Engineering and Management, September 1996, p. 292.
} 
O estudo citado acima, a par de permitir e subsidiar o aperfeiçoamento da redação das minutas utilizadas em vistas das características de risco de cada projeto, revela a probabilidade de ocorrência do hold-up problem como uma circunstância inclusive involuntária.

É evidente, portanto, que, em contexto negocial que exclua considerações sobre diferença de poder de barganha entre as partes ou hipossuficiência de uma delas, bem como a incidência de regras específicas de direito do consumidor e de contratos por adesão que protejam especialmente um dos pólos da relação, a decisão sobre a outorga de permissão ou não, a uma das partes contratantes, para recusar-se a dar cumprimento ao contrato, em razão de alteração superveniente de circunstâncias relevantes do negócio, depende de juízo complexo sobre, entre outros fatores, a natureza da alocação de riscos resultante do regime de preços escolhido pelas partes.

Desde essa perspectiva, um esforço de análise encontrável na literatura já comentada ${ }^{198}$ procura distinguir os riscos controláveis daqueles incontroláveis

Ocorre, de início, que, embora a distinção proposta na passagem referenciada acima possa ser útil à veiculação de juízos sobre a responsabilidade de cada parte em caso de eventos supervenientes como os indicados - tendo por critério seu caráter controlável ou não - ela, porém, não fornece critérios suficientes para que esse juízo seja formulado ou alcançado.

Se um dos critérios importantes para a definição de determinado risco como controlável é a influência de uma das partes na magnitude dos custos decorrentes do risco, um conjunto relevante de eventos que, à primeira vista, podem ser considerados "incontroláveis", inclusive aqueles expressamente mencionados no trecho anteriormente citado ("material price escalation, weather, and unpredictable changes in underground conditions or properties"), assume caracterização menos automática. Por exemplo, a estratégia de compras de determinado empreiteiro - que materiais a serem incorporados à obra serão adquiridos primeiro ou a disponibilidade de instrumentos financeiros de proteção (como hedges de preços de commodities) - tem impacto sensível

\footnotetext{
${ }^{198}$ Vide Seção2.3 3 - Risco, acima.
} 
na magnitude da susceptibilidade ao risco de flutuação de custos de insumos. A aquisição significativa de materiais importantes - como o aço - em obras do tipo considerado, no início da execução dos trabalhos, evidentemente, também reduziria o risco de variação do custo de tal insumo.

Do ponto de vista da variação do custo dos insumos, ainda, pode-se ponderar se a inflação deve ser considerada como controlável ou não, segundo o conceito acima indicado. É óbvio que, dificilmente, um agente econômico singular poderá definir a variação da inflação no país, porém também não se pode desconsiderar que, no contexto brasileiro, a ocorrência de inflação não é uma hipótese implausível. Os mesmos mecanismos de estratégia de compras citados acima poderiam atenuar seu efeito.

Da mesma forma, pode-se investir mais ou menos em estudos de condições geológicas e de solo, com impacto tangível sobre a capacidade de prevenção (ou incorporação de custos) associada a riscos desse tipo.

Ou seja, a consideração de determinado risco como controlável ou incontrolável, desde que se adote do critério uma noção menos trivial, embora sugira um encaminhamento da questão, também não a soluciona, representando mais o enunciado da conclusão de um juízo do que critério para sua formulação, pois sua própria definição não prescinde da avaliação de fatores de considerável complexidade. 


\subsection{A ONEROSIDADE EXCESSIVA NA JURISPRUDÊNCIA}

Como é sabido, a questão da resolução e também revisão do contrato por onerosidade excessiva já foi formulada de diversas maneiras pela doutrina estrangeira e pela brasileira. Tais teorias, que dão fundamento jurídico à flexibilização do vínculo contratual, foram expostas nesse trabalho anteriormente. São essas formulações que fundamentam, no plano teórico, maior flexibilização da máxima pacta sunt servanda.

As construções doutrinárias encontraram maior ou menor recepção no direito positivo brasileiro, que utilizou formulações próprias em diversos diplomas legais, que, por sua vez, não são completamente coincidentes. Assim, encontramos disposições referentes à resolução e à revisão por onerosidade excessiva não somente no Código Civil, como estudado nesta tese, mas também no Código de Defesa do Consumidor (CDC) e na legislação administrativa (Lei 8.666/93).

Em que pesem as diferenças de tratamento dadas pelo legislador a cada um desses casos, a análise da jurisprudência de onerosidade excessiva referente ao CDC e à legislação administrativa pode se revelar útil ao estudo da onerosidade excessiva nos contratos de engineering. Isso porque permite ao operador do direito entender a maneira que os membros do Judiciário internalizaram as diversas teorias e formas de se pensar e analisar a onerosidade excessiva.

Também a justificar a análise deste material está a maior disponibilidade de decisões nestes ramos, dada a introdução destes dispositivos no direito positivo brasileiro antes da consagração de seus correspondentes no novo Código Civil Brasileiro.

No presente capítulo, será feita, portanto, breve análise dessa jurisprudência relativa à onerosidade excessiva. Uma vez que não se trata de tema central da presente tese, tal análise terá como objetivo apenas levantar os fundamentos de decisão dos juízes e 
averiguar até que ponto tal jurisprudência contribui para a determinação dos conceitos do direito positivo, de modo a explicitar e esclarecer as hipóteses de incidência das regras que permitem a revisão ou resolução do contrato por onerosidade excessiva.

\subsubsection{Código de Defesa do Consumidor (CDC)}

Antes de se passar à análise propriamente dita da jurisprudência da onerosidade excessiva no $\mathrm{CDC}$, importante fazer uma observação metodológica quanto à interpretação diferenciada conferida à onerosidade excessiva nesse Código em relação ao regramento do direito civil comum. Essa necessidade decorre do reconhecimento do direito do consumidor como microssistema, colocado pelo legislador à parte do direito privado comum, mas que deve necessariamente ser confrontado e compatibilizado com as disposições gerais deste último.

O direito do consumidor conta com princípios próprios e disposições especiais aplicáveis às relações de consumo. Dentro deste microssistema, aponta Cláudia Lima Marques, impera uma lógica de proteção do consumidor ${ }^{199}$. Para que a finalidade protetiva desse sistema possa ser cumprida, deve o operador do direito utilizar-se deste parâmetro em toda atividade de interpretação e aplicação do direito nas relações abrangidas pelo CDC.

A finalidade de proteção própria do direito do consumidor transparece em quase todas as decisões referentes à onerosidade excessiva em relações de consumo. ${ }^{200}$ Contudo, por vezes, a necessária proteção do consumidor (em razão da sua

${ }^{199}$ Marques, C. L.; Comentários ao Código de Defesa do Consumidor, 2a Ed., São Paulo, RT, 2006, p. 694:

O CDC concentra-se justamente no sujeito de direitos; visa proteger este sujeito, sistematiza suas normas a partir desta idéia básica de proteção de apenas um sujeito "diferente" da sociedade de consumo: o consumidor. É um Código especial para "desiguais", para "diferentes" em relações mistas, entre um consumidor e um fornecedor. É Código de (todo construído sistemático) de Proteção (idéia básica instrumental e organizadora do sistema de normas oriundas de várias disciplinas necessárias ao reequilíbrio e efetivação desta defesa e tutela especial) do Consumidor.

${ }^{200}$ Como exemplo, podemos citar a jurisprudência do STJ nos casos de onerosidade excessiva em contratos leasing reajustados pela variação do dólar americano, em conseqüência da súbita desvalorização cambial ocorrida no ano de 1999. A solução adotada foi de repartir os prejuízos entre as partes envolvidas, em uma solução de eqüidade. Vide, exemplificativamente: 
posição de maior fragilidade nas fases de formação e execução do contrato) resulta em uma flexibilização significativa de certas premissas do direito privado, como a autonomia das partes e a vinculação destas à vontade manifestada no contrato, que, apesar de todas as regras especiais pertinentes ao direito do consumidor permanecem válidas também no microssistema consumerista.

A maior crítica, no entanto, que se pode fazer a essa jurisprudência do CDC é quanto à imprecisão com que o tema da onerosidade excessiva é tratado. Sem grandes dificuldades, percebe-se que o próprio termo "onerosidade excessiva" é utilizado para designar situações diversas. A jurisprudência o utiliza como termo geral que engloba todo tipo de situação em que uma das partes da relação de consumo (geralmente o consumidor) se encontra em situação demasiadamente gravosa em comparação com a outra. A posição subjetiva do devedor passa a ter total preponderância na análise do caso concreto em detrimento do exame do sinalagma estabelecido na formação do contrato.

A configuração de situação demasiadamente gravosa para uma das partes, contudo, não advém necessariamente da ocorrência de um fato superveniente à formação do contrato, nos termos do artigo $6^{\circ}$, inciso $\mathrm{V}$, do CDC. A onerosidade excessiva, nesse sentido lato, pode se configurar já na formação do contrato, isto é, de início o contrato já estabelece prestações tidas como desproporcionais. Nesse caso, o CDC lida

CIVIL. ARRENDAMENTO MERCANTIL. CONTRATO COM CLÁUSULA DE REAJUSTE PELA VARIAÇ̃̃O CAMBIAL. VALIDADE. ELEVAÇÃO ACENTUADA DA COTAÇÃO DA MOEDA NORTE-AMERICANA. FATO NOVO. ONEROSIDADE EXCESSIVA AO CONSUMIDOR. REPARTIÇÃO DOS ÔNUS. LEI N. 8.880/94, ART. $6^{\circ}$. CDC, ART.6 $6^{\circ}$, V.I. Não é nula cláusula de contrato de arrendamento mercantil que prevê reajuste das prestações com base na variação da cotação de moeda estrangeira, eis que expressamente autorizada em norma legal específica (art. $6^{\circ}$ da Lei n. 8.880/94). II. Admissível, contudo, a incidência da Lei n. 8.078/90, nos termos do art. $6^{\circ}$, V, quando verificada, em razão de fato superveniente ao pacto celebrado, consubstanciado, no caso, por aumento repentino e substancialmente elevado do dólar, situação de onerosidade excessiva para o consumidor que tomou o financiamento. III. Índice de reajuste repartido, a partir de 19.01.99 inclusive, eqüitativamente, pela metade, entre as partes contratantes, mantida a higidez legal da cláusula, decotado, tão somente, o excesso que tornava insuportável ao devedor o adimplemento da obrigação, evitando-se, de outro lado, a total transferência dos ônus ao credor, igualmente prejudicado pelo fato econômico ocorrido e também alheio à sua vontade. IV. Recurso especial conhecido e parcialmente provido. (STJ, Segunda Seção, REsp 473140/SP, Rel. Min. Aldir Passarinho, d.j. 12.02.2003)". 
com o tema sob a designação de cláusulas abusivas, que permitem não propriamente a revisão do contrato, mas sim a atividade de extirpação das disposições eivadas de nulidade.

Além das duas possibilidades acima mencionadas, a jurisprudência aponta no art. 39, inciso V, CDC, dentre as ditas práticas abusivas do fornecedor, mais uma hipótese de verificação de onerosidade excessiva que justificaria a revisão ou a resolução contratual.

Em suma, dentro do microssistema do CDC existem várias hipóteses em que se pode fundamentar a atuação do juiz para corrigir condições desfavoráveis ao consumidor, e que, de modo geral, configuram onerosidade excessiva de sua prestação. A jurisprudência invoca esses diferentes fundamentos legais, às vezes, sem atentar para as diferentes nuances de cada um deles.

Na prática, no entanto, a inicial perplexidade causada pela invocação de fundamentos legais diversos do CDC sempre sob a alcunha genérica de onerosidade excessiva pode ser superada ou simplesmente desconsiderada sem maiores problemas, uma vez que não há real interferência no processo de tomada de decisão. Em outras palavras, mesmo que o aplicador do direito não empregue da forma mais técnica possível os termos utilizados, quando da análise do caso prático, acaba por trabalhar com os requisitos correspondentes. Logo, o juiz não irá deixar de atestar uma situação de onerosidade excessiva ocasionada por fato superveniente por confundi-la com aquela gerada por uma cláusula ou prática abusiva. E vice-versa.

É no plano teórico que se encontram as maiores objeções a tal procedimento. A imprecisão terminológica é indicativa da existência de um grau de fluidez conceitual significativa e preocupante, especialmente quando se leva em consideração que esses mesmos aplicadores terão de enfrentar a questão da aplicação de um regime de resolução e revisão contratual com fundamento na onerosidade excessiva do Código Civil. Se há imprecisão conceitual dentro do microssistema do direito do consumidor, há de se temer uma maior dificuldade de interpretação das regras constantes do regime geral do Código Civil, uma vez que essas possivelmente serão interpretadas de acordo com a experiência anterior realizada no seio do CDC, apesar de fazerem parte de um sistema com lógica diferente e de apresentarem traços distintivos bastante significativos. 
Outro sinal de inexatidão, também relacionado à confusão de hipóteses normativas como descrito acima, é a invocação, nas decisões, de diferentes teorias para se justificar a revisão ou resolução do contrato. Algumas falam em teoria da imprevisão, outras em teoria da base do negócio, outras até mesmo em lesão. Ao invés de recorrerem aos parâmetros legais, ${ }^{201}$ várias decisões se valem de teorias que, ou não encontram acolhida integral no direito positivo brasileiro, ou não se referem especificamente ao caso concreto. Esse procedimento causa maior dificuldade de identificação dos requisitos para revisão ou resolução do contrato por onerosidade excessiva $^{202}$.

\footnotetext{
${ }^{201}$ Um bom exemplo de abandono de parâmetros legais em face da aplicação de teorias é a decisão, cuja ementa segue abaixo. Nela, em razão da inaplicabilidade do CDC ao caso em exame, argumenta-se a impossibilidade de se invocar as teorias da quebra da base negocial e da imprevisão, para que se configure a onerosidade excessiva. Sem entrar no mérito da decisão (que, inclusive, parece acertado), deve-se ressaltar a associação do CDC com as mencionadas teorias, demonstrando, ao mesmo tempo, que não se recorre aos critérios do direito positivo e também o desconhecimento da existência de hipóteses de resolução ou revisão do contrato por onerosidade excessiva fora do CDC.
}

Revisão contratual c/ pedido de busca e apreensão e depósito liminar. Contrato de compra e venda com reserva de domínio. Equipamentos médico-hospitalares. Mora do devedor. Protesto. Edital. Possibilidade. O Artigo 1.071 do CPC indica que a mora do comprador será provada com o protesto do título, tão-somente, não exigindo nada além disto, enquanto o Artigo 15 da Lei no 9.492/1997 prevê expressamente a intimação por edital em caso de devedor domiciliado fora da competência territorial do Tabelionato. Rejeição da preliminar. Inaplicabilidade do CDC. O conceito de consumidor adotado pelo CODECON foi exclusivamente de caráter econômico, levando em consideração apenas aquela pessoa, física ou jurídica, que adquire bens ou contrata a prestação de serviços, como destinatário final, visando o atendimento de uma necessidade própria e não para o desenvolvimento de uma outra atividade negocial. A aquisição de equipamentos médico-hospitalares a serem utilizados na prestação de serviços médicos não está incluída na proteção jurídica que se desenvolve em beneficio do consumidor. Precedentes do STJ. Descabe invocar a Quebra da Base Negocial ou Teoria da Imprevisão, ante a inaplicabilidade da Lei Consumerista e porque a flutuação internacional da moeda é algo inteiramente previsível, não encontrando agasalho a tese de onerosidade excessiva, descabendo exigir que a empresa estrangeira que contrata em dólar e cumpre o contrato pelo valor acordado, remetendo as mercadorias compradas, receba valor menor do que aquele pactuado, uma vez que o contrato foi firmado em moeda estrangeira. Viabilidade da contratação em moeda internacional quando o credor é pessoa jurídica estrangeira, na forma do Artigo $2^{\circ}$, IV, do Decreto $n^{\circ} 857 / 69$. Regular o protesto, configurada a mora do devedor e caracterizado o descumprimento contratual, cabe manter a sentença por seus próprios fundamentos.(TJRJ, Ap. Civ. 2006.001.29542, Quinta Câmara Cível, Rel. Roberto Wider, d.j. 29.08.2006). (grifo nosso)

${ }^{202}$ Ementas relacionadas:

Ação de revisão de cláusulas. Contrato de empréstimo pessoal. Caracterizada a relação de consumo. Inaplicabilidade da teoria da onerosidade excessiva. Inocorrência de situação imprevisível. Teoria da base objetiva do contrato, prevista no artigo $6^{\circ}$ inciso v do CDC. Afastada a limitação imposta na lei de 
Além da invocação de teorias diversas, a jurisprudência ainda recorre a princípios e cláusulas gerais do direito do consumidor e mesmo do direito constitucional. Podemos citar a função social dos contratos, o dever de informação e transparência do fornecedor, o necessário atendimento a fins sociais, entre outros ${ }^{203}$.

usura, aplicando-se as taxas de juros balizadas no contrato e regras de mercado (súmula 596 do STF). No entanto, continua sendo vedada a pratica de anatocismo. In casu, a prova pericial não constatou a capitalização mensal de juros, o que evidencia a prática de anatocismo. Manutenção do decisum. Recurso conhecido e improvido. (TJRJ, Décima Quarta Câmara Cível, Ap. Civ. 2005.001.04884, Rel. Ferdinaldo do Nascimento, d.j. 09.08.2005). (grifo nosso)

Civil. Contrato de compra e venda com reserva de domínio. Preço em moeda estrangeira. Alteração cambial que desvalorizou a moeda nacional perante a moeda estrangeira, acarretando desequilíbrio contratual. Teoria da imprevisão. Onerosidade excessiva. Comprovação. Mitigação do princípio da autonomia contratual e obrigatoriedade dos contratos, em razão da previsão constitucional do princípio da função social dos contratos. Aplicabilidade do princípio da boafé objetiva norteador da teoria geral dos contratos, ainda na vigência do Código Civil de 1916, eis que se trata de cláusula geral. Revisão contratual pertinente, visando equilibrar as relações jurídicas. Negado provimento ao recurso. (TJRJ, Segunda Câmara Cível, Ap. Civ. 2005.001.26945, Rel. Antônio Saldanha Palheiro, d.j. 19.10.2005). (grifo nosso)

Cartão de crédito - cobrança de juros e encargos acima dos legalmente autorizados. Contrariedade à lei da usura. Não estando as administradoras de cartões de crédito sob a regência das normas que disciplinam o sistema financeiro, sujeitam-se às limitações de juros impostas pela lei da usura - lei 22626/33. Ocorrência da cobrança excessiva de juros, encargos e multa, contrariando legislação em vigor, dispensando a prova pericial contábil. Nulidade das cláusulas permissivas. Vedação da cláusula mandato - artigo 51 VIII do CDC e súmula n ${ }^{\circ} 60$ do S.T.J. Prática abusiva, inclusive por se tratar de cláusula potestativa pura conforme art. 115 (atual art. 122) do CCB. Condições estabelecidas unilateralmente pelo fornecedor do serviço, sem anuência ou mesmo prova do conhecimento do consumidor. Infrigência ao princípio da transparência máxima art, $4^{\circ}$, caput e $6^{\circ}$ III do CDC. Princípio da força obrigatória dos contratos, ora mitigado, no âmbito do estado democrático de direito, à proteção do consumidor como direito fundamental, art. $5^{\circ}$, XXXII cf/88. Teoria da lesão, induvidosamente acatada pelo inciso v do art. $6^{\circ}$ do CDC c/c art. 480 do Código Civil de 2002. Onerosidade excessiva do contrato que demanda a intervenção do judiciário para reequilíbrio do pacto. Efeito ex tunc, que macula o suporte contratual das referidas cláusulas desde seu nascimento e as operações delas decorrentes. Após o advento do CDC - lei 8078/90, não se mostra razoável a realização de operações manifestamente ilegais sob o argumento de tratar-se de matéria controvertida. Relação de consumo que possibilita a faculdade da inversão do ônus da prova. Provimento do recurso. (TJRJ, Décima Terceira Câmara Cível, Ap. Civ. 2003.001.18840, Rel. Antônio Saldanha Palheiro, d.j. 17.09.2003). (grifo nosso)

${ }^{203}$ Ementas relacionadas:

Direito do consumidor. Recurso especial. Ação de conhecimento sob o rito ordinário. Cessão de crédito com anuência do devedor. Prestações indexadas em moeda estrangeira (dólar americano). Crise cambial de janeiro de 1999. Onerosidade excessiva. Caracterização. Boa-fé objetiva do consumidor e direito de informação. - $\mathrm{O}$ preceito insculpido no inciso $\mathrm{V}$ do artigo $6^{\circ}$ do $\mathrm{CDC}$ 
dispensa a prova do caráter imprevisível do fato superveniente, bastando a demonstração objetiva da excessiva onerosidade advinda para o consumidor. - A desvalorização da moeda nacional frente à moeda estrangeira que serviu de parâmetro ao reajuste contratual, por ocasião da crise cambial de janeiro de 1999, apresentou grau expressivo de oscilação, a ponto de caracterizar a onerosidade excessiva que impede o devedor de solver as obrigações pactuadas. - A equação econômico-financeira deixa de ser respeitada quando o valor da parcela mensal sofre um reajuste que não é acompanhado pela correspondente valorização do bem da vida no mercado, havendo quebra da paridade contratual, à medida que apenas a sociedade de fomento ao crédito estará assegurada quanto aos riscos da variação cambial. - É ilegal a transferência de risco da atividade financeira ao consumidor, ainda mais quando não observado o seu direito à informação. (STJ,Terceira Turma, Resp 417927/SP, Rel. Min. Nancy Andrighi, d.j. 21.05.2002) (grifo nosso)

Reintegração de posse. Arrendamento mercantil. Mora. Reconvenção. Revisão de cláusula contratual. Variação cambial. Aplicação do previsto no artigo $6^{\circ}$, inc. $\mathrm{V}$, do CDC. A cláusula que estipule o reajuste de prestações de contrato de arrendamento mercantil com base na variação cambial, viola os princípios consumeristas basilares da transparência, da confiança e da boa fé objetiva. Onerosidade excessiva decorrente de fatos supervenientes e inesperados. Releitura do pacto. Rompimento da base negocial. Substituição da vinculação cambial por outro índice que melhor reflita a justa proporcionalidade. Se o réu pagou 31, de um total de 36 parcelas, deixando de pagar as últimas, em razão da ilegal aplicação da variação cambial, cabe acolher o pedido reconvencional, para determinar a substituição da variação cambial pelo IGPM com relação às prestações vencidas e a imediata reintegração do réu na posse do bem. Precedentes da Corte. Sentença reformada. (TJRJ, Quinta Câmara Cível, Ap. Civ. 2005.001.00723, Rel. Roberto Wider)

"EMENTA: POSSE E PROPRIEDADE DE BENS MÓVEIS. AÇÃO DE RESOLUÇÃO CONTRATUAL. CONTRATO DE EXECUÇÃO CONTINUADA. ONEROSIDADE EXCESSIVA SUPERVENIENTE AO AJUSTE POR FATO DO PRÍNCIPE (RESOLUÇÃO DA ANVISA AGÊNCIA NACIONAL DE VIGILÂNCIA SANITÁRIA) A JUSTIFICAR O PEDIDO DE RESOLUÇÃO DO CONTRATO. APLICAÇÃO DO ART. 478 DO CÓDIGO CIVIL DE 2.002. EFEITOS DA SENTENÇA. A moderna tendência da teoria dos contratos, infensa à rigidez do axioma pacta sunt servanda é adotada pelo atual Código Civil, que exalta a função social do contrato como cláusula geral. Nesse passo, impõe-se o acolhimento do pedido de resolução do contrato que se tornou excessivamente oneroso para uma das partes, mesmo que por ato alheio ao do credor. Os efeitos da sentença devem, consoante o disposto no artigo 478 do $\mathrm{CPC}$, retroagir à data da citação. Primeira apelação parcialmente provida. Segunda apelação prejudicada. (Apelação Cível No 70009546888, Décima Quarta Câmara Cível, Tribunal de Justiça do RS, Relator: Sejalmo Sebastião de Paula Nery, Julgado em 16/03/2006).

Embargos infringentes - Arrendamento mercantil - Cláusula de reajuste de acordo com a cotação do dólar - Ação revisional julgada procedente e mantida em grau de apelação - Teoria da imprevisão que é diferente no Código Civil e no Código de Defesa do Consumidor. CDC que se contenta com a onerosidade excessiva, prescindindo da imprevisibilidade - Alegação de recursos captados no exterior - Julgador que, na aplicação da lei, deve estar atento aos fins sociais a que ela se destina (art. $5^{\circ}$ da LICC) - Princípio que, na órbita consumerista, se traduz na ponderação de forças entre o fornecedor e o consumidor - Avaliação concreta da capacidade de cada uma das partes de suportar ônus decorrentes das relações estabelecidas - Entidades financeiras que se cercam de cautelas que impedem ou minimizam prejuízos das flutuações verificadas - Embargos 
Importante notar que não se pretende com isso menosprezar a importância das cláusulas gerais, nem sua utilidade como parâmetros de interpretação e valoração das disposições legais. Podem ser apontados, no entanto, dois riscos na sua utilização: a criação inadvertida de requisitos para a revisão ou resolução não previstos na própria lei ${ }^{204}$ (como, por exemplo, a boa ou má-fé do fornecedor) e também a existência de um espaço de decisão por demais amplo. Em outras palavras, o atendimento ao interesse social pode comportar, eventualmente, decisões diametralmente opostas e, às vezes, incompatíveis com outros dispositivos, que têm de necessariamente ser afastados ${ }^{205}$.

infringentes rejeitados ( $2^{\circ}$ TACivSP $-12^{\text {a }}$ Câm. - EI 694.678-2/8 - rel. Juiz Romeu Ricupero - j. 13.12.2001)”.

${ }^{204}$ Constitui exemplo da citada consideração de requisitos não previstos no CDC:

CIVIL E PROCESSUAL CIVIL. CONSIGNAÇÃO EM PAGAMENTO. REVELIA. PRESUNÇÃO RELATIVA DE VERACIDADE. CONTRATO DE ABERTURA DE CRÉDITO. REVISÃO DE CLÁUSULAS. NECESSIDADE DE FATO SUPERVENIENTE A ENSEJAR ONEROSIDADE EXCESSIVA. VÍCIO NO NEGÓCIO JURÍDICO. INOCORRÊNCIA. DESPROVIMENTO. 1. A presunção de veracidade dos fatos alegados pelo autor na inicial decorrente da revelia é relativa, pois do conjunto probatório dos autos pode resultar em raciocínio-lógico contrário, derrubando a presunção que favorecia o autor. 2. Os princípios da livre autonomia da vontade e da força obrigatória que informam o contrato não mais possuem o sentido absoluto outrora lhes atribuído, sendo manifestamente aceita, em determinadas situações, a intervenção judicial no conteúdo dos contratos, e, por conseguinte, a contenção de sua força obrigatória. 3. A teor do disposto no art. $6^{\circ}$, inc. $\mathrm{V}$, da Lei $\mathrm{n}^{\circ} 8.078 / 90$, a modificação de cláusula de contrato de abertura de crédito exige a inexperiência de um contratante ou o abuso do poder econômico, e a revisão reclama a superveniência de fatos ou acontecimentos que tornem as prestações excessivamente onerosas, provocando desequilíbrio contratual, o que não se verifica na hipótese. 4. Recurso desprovido. (TJDFT, 20040110554695APC, Relator Mario-Zam Belmiro, $3^{\text {a }}$ Turma Cível, julgado em 09/01/2006, DJ 21/03/2006 p. 101). (grifo nosso)

${ }^{205}$ A ementa abaixo trata de onerosidade excessiva decorrente da existência de cláusula abusiva. É, portanto, onerosidade excessiva existente já na gênese do contrato. $O$ interesse de transcrevê-la, mesmo não sendo este o objeto de estudo desta tese, está em exemplificar a utilização de um princípio geral (interesse social) para se justificar uma decisão que não poderia ser tomada frente aos parâmetros legais. Nessa decisão, como se pode verificar pela consulta ao voto do relator, a taxa de juros seria abusiva e, portanto, passível de revisão judicial pela simples razão de existirem no mercado outras taxas de juros mais baixas. O raciocínio tortuoso é justificado juridicamente por um suposto atendimento ao interesse social.

CARTÃO DE CRÉDITO - REVISÃO DA TAXA DE JUROS. - 1. As administradoras de cartão de crédito são instituições financeiras (Súm. 283 STJ) e não estão sujeitas à Lei da Usura (Súm. 596 - STF). 2. A norma constitucional que tabelava os juros, revogada pela EC 40/2003, tinha aplicabilidade condicionada à edição de lei complementar (Súm. 648 - STF). - 3. Anatocismo vedado pela Súm. 121 - STF, mas não comprovado. - 4. A nova concepção social do contrato. Intervenção do Judiciário no intuito de relativizar o dogma da autonomia da vontade e ajustar a execução do contrato ao interesse social, afastando a onerosidade excessiva para o consumidor (art. 39, V, CDC) e 
Um dos maiores exemplos das dúvidas que surgem da imprecisão com que se trata a onerosidade excessiva na jurisprudência diz respeito à necessidade de verificação de imprevisibilidade do fato superveniente. No direito do consumidor, já se reconheceu, inclusive pelo STJ, a desnecessidade do fato superveniente causador de onerosidade excessiva ser imprevisível. Isso porque o CDC não o exige em seu art. $6^{\circ}$, inciso $V .^{206}$ Não obstante, existem, mesmo assim, decisões ainda hoje que exigem a imprevisibilidade mesmo em relações regidas pelo $\mathrm{CDC}^{207}$ Essa confusão, em geral, vem da dificuldade de se diferenciar os requisitos do CDC e do Código Civil para a revisão ou resolução do contrato por onerosidade excessiva: a imprevisibilidade é requisito somente no Código Civil. ${ }^{208}$

Em suma, até esse ponto, procurou-se demonstrar que a jurisprudência relativa ao CDC não trata de forma muito precisa ou técnica as categorias jurídicas relacionadas à onerosidade excessiva. Ora, se já há certa insegurança quanto à

o enriquecimento indevido do fornecedor (art. 884, CC). - 5. Abusividade da taxa de juros. Redução ao percentual do "crédito pessoal". - 6. Recurso parcialmente provido. (TJRJ, Décima Câmara Cível, Ap. Civ. 2006.001.10610, Rel. Paulo Mauricio Pereira, d.j. 28.03.2006). (grifo nosso)

${ }^{206}$ Vide primeira e última ementas transcritas na nota de rodapé 203, acima.

${ }^{207}$ Por exemplo:

PLANO DE SAÚDE - Agravo contra decisão que concedeu tutela antecipada para realização de tratamento médico - Não cabimento - Caso de urgência médica com risco de vida - Não há que se falar em falta de interesse porque o agravado tinha conhecimento das exclusões em negrito constantes do contrato Entendimento que os procedimentos de saúde cobertos pelos Planos não podem sofrer limitações, quando o paciente está em tratamento, para proteção do direito à vida, previsto no art. $5^{\circ}$ da $\mathrm{CF}$ - É abusiva a exclusão contida no contrato, nos termos do art. $6^{\circ}$ do Código do Consumidor - A vetusta cláusula rebus sic stantibus do Direito Romano integra o Código do Consumidor no art. $6^{\circ}, \mathrm{V}-$ Presentes os requisitos da imprevisibilidade e da onerosidade excessiva - A cláusula rebus sic stantibus faz parte do Código Civil de 2002, arts. 478 a 480 Preliminar rejeitada e, no mérito - Recurso improvido. (TJSP, Agravo de Instrumento n. 351.957-4/7 - Campinas - $8^{\mathrm{a}}$ Câmara de Direito Privado - Relator: Ribeiro da Silva - 27.10.04 - V.U.). (grifo nosso)

208 Imprevisibilidade que, pelos estudos desenvolvidos no âmbito do STJ, seria entendida nos termos dos Enunciados 17, 175 e 176 do Centro de Estudos Judiciários (CEJ): "17 - Art. 317: a interpretação da expressão "motivos imprevisíveis" constante do art. 317 do novo Código Civil deve abarcar tanto causas de desproporção não previsíveis como também causas previsíveis, mas de resultados imprevisíveis." - "175 Art. 478: A menção à imprevisibilidade e à extraordinariedade, insertas no art. 478 do Código Civil, deve ser interpretada não somente em relação ao fato que gere o desequilíbrio, mas também em relação às conseqüências que ele produz." - "176 - Art. 478: Em atenção ao princípio da conservação dos negócios jurídicos, o art. 478 do Código Civil de 2002 deverá conduzir, sempre que possível, à revisão judicial dos contratos e não à resolução contratual." 
matéria estritamente jurídica, mais razão para se temer uma atuação equivocada do juiz quando necessita adentrar a verificação da onerosidade excessiva em uma perspectiva mais estritamente econômica, uma vez que a formação dos juízes e operadores do direito em geral tende a ser deficitária neste aspecto.

Algumas decisões, acertadamente, explicitam a necessidade de se comprovar a situação de onerosidade excessiva, seja recorrendo-se a uma perícia, ${ }^{209}$ seja comprovando de outro modo o impacto econômico da ocorrência de fato superveniente. Essa não é, contudo, posição predominante. Muito freqüentemente a decisão judicial faz análise apenas superficial da situação de fato antes de se reconhecer a presença ou não de onerosidade excessiva na prestação. E a superficialidade da análise, sob a perspectiva econômica, pode levar a situações de flagrante injustiça, pois a decisão, ao invés de reparar o desequilíbrio ocasionado por fato superveniente, o mantém, ainda que em outros termos, ou então cria ela mesma outra situação de desequilíbrio. ${ }^{210}$

${ }^{209}$ Ementa relacionada:

Ação de Consignação em Pagamento - Contrato de Arrendamento Mercantil Alegação de desequilíbrio contratual e onerosidade excessiva, em virtude de redução das taxas de juros, bem como indevida a cobrança de encargos. Aplicação do Código de Defesa do Consumidor, que nos artigos $4^{\circ}$, inciso III, $6^{\circ}$, inciso $\mathrm{V}$ e 51 , parágrafo $1^{\circ}$, inciso III, possibilitam a revisão de cláusulas contratuais quando ocorrer onerosidade excessiva. No mesmo sentido os artigos 478 e 480 do Código Civil. Não basta ao arrendatário alegar a existência de desequilíbrio contratual, onerosidade excessiva, cobrança indevida de encargos e apontar o valor que pretende consignar, sem justificar, por critérios técnicos e contábeis, como chegou aos valores apresentados na petição inicial, não havendo a juntada aos autos do Contrato de Arrendamento Mercantil firmado pelas partes para viabilizar a análise da questão pelo Poder Judiciário, ou a produção de prova pericial para comprovar o desequilíbrio contratual. O ônus da prova, de demonstrar a veracidade dos fatos narrados, é do autor, artigo 331, inciso 1 do Código de Processo Civil - Desprovimento do recurso. (TJRJ, Décima Sétima Câmara Cível, Ap. Civ. 2005.001.20925, Rel. Camilo Ribeiro Ruliere, d.j. 09.11.2005). (grifo nosso)

${ }^{210}$ Por exemplo:

Processual civil. Coisa julgada. Ação revisional de contrato de prestação de serviços de telefonia fixa cumulada com pedido de antecipação de tutela. Sentença proferida em sede de juizado especial cível impondo ao apelado obrigação de fazer que, na sua concepção, lhe causa onerosidade excessiva e daí postula sua revisão. Alegação de nova causa de pedir e outro pedido. Pretensão albergada em sofisma, a qual, na verdade, busca extinguir o efeito preclusivo da coisa julgada da anterior ação, ao invés de se embasar no art. 471, i, do Código de Processo Civil. Sentença terminativa que se impõe com o reconhecimento da coisa julgada, dado o seu efeito preclusivo. Recurso provido. (TJRJ, Quinta Câmara Cível, Ap. Civ. 2006.001.22514, Rel. Antônio Saldanha Palheiro, d.j. 08.08.2006). (grifo nosso) 
Passemos agora à análise da jurisprudência referente à onerosidade excessiva nos contratos administrativos.

\subsubsection{Contratos Administrativos}

Nos contratos administrativos, a questão da onerosidade excessiva é discutida dentro do tema do equilíbrio econômico-financeiro do contrato. Também conhecido como equação financeira do contrato, esse equilíbrio é entendido como a relação original entre encargos do particular e a contraprestação assegurada pela Administração. Não se entende que esse equilíbrio seja uma equivalência perfeita, no sentido econômico, entre as obrigações das partes. Como foi dito acima, o equilíbrio econômico-financeiro é aferido a partir da relação originária entre as prestações. É, portanto, decorrente da realização de uma proposta pelo particular e a sua escolha pela Administração como a mais vantajosa. É nesse sentido que se deve entender a garantia do artigo 37, inciso XXI, da Constituição Federal, no que se refere à manutenção das condições efetivas da proposta.

A readequação da contraprestação da administração para que se assegure o equilíbrio econômico-financeiro do contrato pode ser realizada em diversas

A decisão remete ao seguinte caso: decisão proferida em Juizado Especial Cível limitou a possibilidade da operadora de telefonia de cobrar pelas ligações realizadas pelo usuário além do valor da assinatura. A decisão, contudo, não permitia também que se interrompesse a prestação do serviço quando atingido o referido valor. Desse modo, a operadora ficava obrigada a prestar o serviço, no que ultrapassasse o valor da assinatura, sem a respectiva remuneração. A ementa aqui transcrita refere-se à ação intentada posteriormente, para reverter essa situação, tida como de onerosidade excessiva. O entendimento, no entanto, final foi da impossibilidade de acolhida desse pedido, por ele, supostamente, pretender violar a coisa julgada da ação anterior. A decisão, aqui, por privilegiar o formalismo, acabou por preservar situação de injustiça originada em outra decisão judicial. Diferente solução, para problema semelhante, como segue:

Telefonia. Condenação no Juizado Especial Cível. Limitação das cobranças ao valor da franquia. Sentença determinativa que permite integração posterior, conforme artigo 471, inciso I, do CPC. Onerosidade excessiva reconhecida pelo próprio poder concedente. Matéria objeto de uniformização de jurisprudência nesta Corte Estadual. Interpretação sistemática dos artigos 22, caput, do CDC e artigo 478 do novo Código Civil. Nulidade que se deixa de reconhecer na forma do artigo $245 \S 2^{\circ}$ do CPC. Sentença de improcedência reformada. Apelação provida. (TJRJ, Décima Câmara Cível, Ap. Civ. 2006.001.06315, Rel. Bernardo Moreira Garcez Neto, d.j. 04.04.2006). 
situações. Ela é pensada em primeiro lugar na situação de alteração unilateral do contrato. Essa prerrogativa da Administração decorre da supremacia do interesse público, que, para ser atendido, autorizaria, inclusive, alterações contratuais à revelia do particular. Como garantia para este, a possibilidade de revisão do contrato.

A lei também faz previsão de que a readequação seja realizada em situações em que fatos imprevisíveis impliquem em onerosidade excessiva, em paralelo à onerosidade excessiva do Código Civil e do CDC. Essa hipótese está prevista no art. 65, inciso II, d, primeira parte, da Lei 8.666/93.

Importante notar que a lei imprime um caráter de excepcionalidade a essas hipóteses de revisão: a dificuldade tem de ser extraordinária e causada por fatos imprevisíveis ou cujas conseqüências sejam imprevisíveis. ${ }^{211}$

Outra demonstração de excepcionalidade está em se definir o fato autorizador da revisão do contrato por quebra do equilíbrio econômico-financeiro como álea imprevisível e extracontratual. Assim, é um fato não contemplado na avença original

${ }^{211}$ Ementa relacionada:

A aplicação da teoria da imprevisão dá lugar quando fatos novos, imprevistos ou imprevisíveis, ou ainda previsíveis, mas de conseqüências incalculáveis, estranhos à vontade das partes, causam desequilíbrio do contrato e refletem na economia e na execução do mesmo, importando em sua alteração a fim de restabelecer a relação que as partes pactuaram inicialmente. Somente se cogitará em se restabelecer o equilíbrio econômico-financeiro do contrato quando presentes os pressupostos fáticos previstos em lei, isto é, fatos imprevisíveis, ou previsíveis, porém de conseqüências incalculáveis, retardadores ou impeditivos da execução do ajustado, ou ainda, em caso de força maior, caso fortuito ou fato do príncipe, configurando álea econômica extraordinária e extracontratual. $\mathrm{O}$ aumento do piso salarial da categoria é fato previsível e de conseqüências calculáveis, razão pela qual não se aplica o art. 65, II, da Lei $n^{\circ}$ 8.666/93. Conseguintemente, não se verifica o rompimento do equilíbrio econômicofinanceiro do contrato, eis que caberia à autora formular proposta, tendo em conta as circunstâncias previsíveis, não se podendo imputar à Administração o ônus de arcar com possíveis prejuízos causados pela omissão da própria contratada. Por conseqüência, não se pode admitir a seleção e contratação de licitante, oferecedor de preços fictícios, para, após o aperfeiçoamento do vínculo com a Administração Pública, proceder-se a reajustamento dos preços. Esse procedimento implicaria em burla à regra constitucional da licitação e à própria base principiológica do Direito Administrativo". (TRF 5 Região, $2^{\mathrm{a}}$ Turma, AC 341792, Rel. Francisco Cavalcanti, d.j. 21/09/2004). 
entre particular e Administração e que altera profundamente a relação entre a contraprestação e os encargos do particular. ${ }^{212}$

Importante observar, ainda, que a lei trata juntamente com a hipótese de onerosidade excessiva descrita acima, as situações de força maior, caso fortuito e fato do príncipe, que autorizariam também a revisão do contrato. Nessas situações também se faz necessário restabelecer o equilíbrio econômico-financeiro do contrato, porém, as hipóteses são diferentes. Como visto acima, quando se fala em força maior ou caso fortuito, quer-se designar situação de impossibilidade de cumprimento da obrigação e não especificamente de dificuldade por a prestação ter se tornado excessivamente onerosa para uma das partes. E, quanto ao fato do príncipe, é atuação da Administração que afeta negativamente o modo ou as condições de prestação pelo particular. Alguns arestos o diferenciam em relação à alteração unilateral do contrato pela Administração, pois fato do príncipe seria atuação da Administração que atinge uma generalidade, enquanto a alteração unilateral cuida de atuação direcionada para o contrato ${ }^{213}$.

${ }^{212}$ Ementas relacionadas:

A teoria da imprevisão somente é aplicável quando fatos posteriores ao contrato, imprevistos e imprevisíveis pelas partes contratantes e a elas não imputáveis, modificam profundamente o equilíbrio contratual. Tendo em vista que o aumento anual do salário mínimo não constitui fato imprevisto nem imprevisível pelas partes contratantes, é inaplicável à espécie o disposto no artigo 65, II, "d", da Lei $8.666 / 93$ para impor a revisão do preço contratado, sob o fundamento de quebra do equilíbrio econômico-financeiro do contrato".(TRF $1^{\mathrm{a}}$ Região, $3^{\mathrm{a}}$ Turma suplementar, AC 199901000564982, Rel. Leão Aparecido Alves, d.j. $12 / 02 / 2004)$.

O contrato firmado entre a apelante e a Administração Pública data de 14 de maio de 1991, ou seja, quando já estava em vigor o disposto no artigo $9^{\circ}$ da Lei 8.178 , de $1^{\circ}$ de março de 1991, o que demonstra a absoluta ausência de modificação das condições econômico-financeiras do contrato, eis que a disposição legislativa já existia quando ele foi assinado. Dessa forma, é incabível a invocação da teoria da imprevisão, pois ela somente é aplicável quando fatos posteriores ao contrato, imprevistos e imprevisíveis pelas partes contratantes e a elas não imputáveis, modificam profundamente o equilíbrio contratual" (TRF $1^{\text {a }}$ Região, $3^{\text {a }}$ Turma suplementar, AC 9501197611, Rel. Leão Aparecido Alves, d.j. 12/12/2001).

213 Em conformidade com o art. $65, \S 5^{\circ}$, Lei 8.666/93, em razão da ausência de repercussão direta sobre os preços contratados:

A COFINS incide sobre o total da receita bruta da pessoa jurídica e não diretamente sobre o valor da remuneração paga ao trabalhador. Ausente o impacto direto do encargo sobre a prestação, não há como aplicar a regra do artigo $65, \S 5^{\circ}$, da Lei $n^{\circ} 8.666 / 93$. Essa interpretação da lei afasta a alegação de cerceamento de defesa em virtude da ausência de perícia para verificar a repercussão do aumento da alíquota sobre o custo da mão-de-obra. Em um ambiente de estabilidade do poder aquisitivo do real, o aumento do piso salarial 
Em suma, as possibilidades de revisão do contrato administrativo para restaurar seu equilíbrio econômico-financeiro são diversas, mas apenas uma delas diz respeito à onerosidade excessiva da prestação por fato superveniente imprevisível ou de conseqüências imprevisíveis.

Uma particularidade da revisão do contrato por onerosidade excessiva, no âmbito dos contratos administrativos, é o entendimento de que a manutenção do equilíbrio econômico-financeiro do contrato não só é direito do particular, mas também seria meio de se assegurar o interesse público, que não se resumiria a manter tarifas baixas ou assegurar o menor gasto pela Administração. O interesse público residiria também na continuidade e boa prestação do serviço público. ${ }^{214}$

Desse entendimento, de que se protege o interesse público quando se revisa a remuneração do particular, de acordo com o apresentado acima, pode-se tirar a conclusão de que contratar com a Administração acaba sendo um negócio vantajoso para o particular, na medida em que as diversas possibilidades de revisão do contrato são entendidas também como tendentes a proteger o interesse público. A possibilidade de o contrato ser revisto para ser cumprido naquelas condições originárias diminui os riscos de o particular ter de realizar sua prestação sob condições alteradas e adversas, lhe ocasionando prejuízo, com o qual não contava.

A discussão gira, afinal, em torno de quais riscos e dificuldades na prestação o particular deve assumir e quais não. Em outras palavras, discute-se o que é fato previsível e o que é fato imprevisível, e que, por isso, quando da sua ocorrência, ensejaria

${ }^{214}$ Ementa relacionada:

dos trabalhadores ou do valor do tíquete-alimentação não constitui fato imprevisível ou previsível de conseqüências incalculáveis, principalmente considerando a periodicidade anual de prorrogação da prestação do serviço". (TRF 4 Região, 3 ${ }^{\mathrm{a}}$ Turma, AC, Processo 200070000211578, Rel. Francisco Donizete Gomes, d.j. 29/10/2002)

Necessária a manutenção do equilíbrio-financeiro dos contratos celebrados com o Poder Concedente, porque o interesse público não se resume à contenção de tarifas, sendo evidenciado, também, na continuidade e qualidade do fornecimento de energia, na manutenção do contrato, de modo a viabilizar investimentos no setor, para que o país não volte à escuridão". (STJ, Corte Especial, AGRSLS 162, Rel. Edson Vidigal, d.j. 15/03/2006) 
revisão do contrato administrativo ${ }^{215}$. Em outras palavras, a jurisprudência procura identificar se os fatos que causam impacto na execução do contrato podem ser qualificados como imprevisíveis ou de conseqüências imprevisíveis. Sem isso, a jurisprudência não costuma autorizar a revisão do contrato para restaurar o equilíbrio econômico-financeiro.

Como se abordará em maior detalhe no capítulo seguinte, ao tratar da Teoria dos Contratos Incompletos, um passo além do que foi exposto acima, da diferenciação entre fatos imprevisíveis e previsíveis, é procurar explicitar a razão pela qual fatos previsíveis não ensejam a revisão para readequação do equilíbrio econômicofinanceiro. Reconhecer que certas situações são previsíveis significa que elas devem ter sido objeto de estipulação contratual, seja expressa ou implicitamente. Expressamente quando veiculada por dispositivo contratual que enfrenta diretamente a possibilidade de ocorrência do fato alterador das condições iniciais de execução do contrato, prevendo já solução adequada à ocorrência desse fato. Portanto, não se tem dificuldades de se reconhecer a impossibilidade de revisão para reajustar o contrato à sua equação financeira original quando o contrato já trata expressamente dessa possibilidade.

Um pouco diferente é a situação em que o contrato não prevê expressamente o fato alterador das condições de execução do contrato. Nesse caso, por ser o fato previsível, mesmo na falta de disposição expressa, deve-se entender que o particular levou em consideração tal situação quando da formulação da proposta. Em outras palavras,

${ }^{215}$ Ementas relacionadas:

O aumento salarial a que está obrigada a contratada por força de dissídio coletivo não é fato imprevisível capaz de autorizar a revisão contratual de que trata o art. 65 da Lei 8.666/93”. (STJ, 2 ${ }^{\text {a }}$ Turma, RESP 411101, Rel. Eliana Calmon, d.j. 07/08/2003)

A revisão destinada a manter o equilíbrio econômico-financeiro dos contratos administrativos admitida pela Constituição (art. 37, XXII) e pelas Leis $\mathrm{n}^{\mathrm{o}} \mathrm{s}$ $8.666 / 93$ (arts. $57, \S 1^{\circ}, 58, \S \S 1^{\circ}$ e $2^{\circ}$, e 65 ) e $8.987 / 95$ se dá apenas em razão de mudança na situação de fato existente no momento da proposta ou da contratação, não bastando mero equívoco do proponente na avaliação das circunstâncias do negócio”. (TRF 1 1 Região, 5 ${ }^{\mathrm{a}}$ Turma, AC 200034000200765, Rel. João Batista Moreira, d.j. 30/08/2004)

Não dá margem ao reajuste para manter o equilíbrio econômico-financeiro do contrato, o fato de ter o licitante omitido encargos trabalhistas devidos por força de convenção coletiva de trabalho (vale alimentação) do qual tomou conhecimento antes da assinatura do contrato. Tal situação não se caracteriza como fato imprevisível”. (TRF 1ª Região, 6 ${ }^{\mathrm{a}}$ Turma, AC 200001000813580, Rel. Maria Isabel Gallotti Rodrigues, d.j. 01/04/2002) 
situações previsíveis são objeto de cálculo pelo particular ao formular sua proposta, mesmo que isso não tenha se convertido em uma cláusula expressa no contrato, determinando certa providência ou alteração na execução quando da ocorrência de tal hipótese. ${ }^{216}$

Nesse sentido, não parece procedente o entendimento de Marçal Justen Filho, segundo o qual não faria sentido o contrato prever situações meramente possíveis $^{217}$. De um modo ou de outro, isso já acontece e nem por isso deve ser autorizada a readequação do contrato, uma vez que não constar do contrato não significa que o particular não tenha levado em consideração ou não devesse ter levado em consideração tal risco e se precavido contra ele. A distinção de Marçal, inclusive, parte de uma análise de probabilidade de ocorrência e não de previsibilidade. Ela parte, portanto, de uma análise de conveniência da inclusão de certas cláusulas, entendendo sempre possível a revisão do contrato na eventual ocorrência dessas situações menos prováveis. $\mathrm{O}$ autor desconsidera, assim, a diferenciação feita pela lei e pela jurisprudência entre fatos previsíveis e imprevisíveis.

${ }^{216}$ Ementa relacionada:

1. Não constitui fator exógeno e imprevisível a ponto de ensejar a aplicação da Teoria da Imprevisão e justificar o realinhamento da equação financeira do contrato o aumento salarial decorrente de acordo coletivo. 2. Não é crível que uma empresa prestadora de serviços como a autora não esteja afeita aos acordos coletivos e não possa calcular o impacto deles sobre o preço a ser cotado quando participa de uma licitação. É fato completamente previsível. 3. "A não inclusão, nos custos, de uma expectativa de crescimento da despesa de pessoal, revela a desconsideração, de um plus, perfeitamente dimensionável pelos dados estatísticos antecipadamente divulgados pelos sindicatos obreiro e patronal" (MAS 1998.01.00.013010-1/DF). 4. A não consideração desse aspecto no momento em que o preço é cotado pode deixar a Administração em difícil situação perante as demais empresas que competiram, além de poder ter o condão de revelar o ardil de que se valeu a empresa vencedora. 5. Remessa oficial e apelação providas". (TRF 1ª Região, AMS 199701000288037, Rel. Carlos Alberto Simões de Tomaz, d.j. 08/05/2003)

${ }^{217}$ Trecho relacionado:

A tutela do equilíbrio econômico-financeiro dos contratos administrativos destina-se a beneficiar à própria Administração. Se os particulares tivessem de arcar com as conseqüências de todos os eventos danosos possíveis, teriam de formular propostas mais onerosas. A Administração arcaria com os custos correspondentes a eventos meramente possíveis - mesmo quando inocorressem, o particular seria remunerado por seus efeitos meramente potenciais. É muito mais vantajoso convidar os interessados a formular a menor proposta possível: aquela que poderá ser executada se não se verificar qualquer evento prejudicial ou oneroso posterior. Concomitantemente, assegura-se ao particular que, se vier a ocorrer o infortúnio, o acréscimo de encargos será arcado pela Administração. Em vez de arcar sempre com o custo de eventos meramente potenciais, a Administração apenas responderá por eles se e quando efetivamente ocorrerem. Trata-se, então, de reduzir os custos de transação atinentes à contratação com a Administração Pública" in Comentários à lei de licitações e contratos administrativos, São Paulo, 2002, $9^{\mathrm{a}}$ ed., Dialética, p. 499-500 
Importante aqui reiterar a diferença entre a falta de cláusula expressa e a falta de previsão contratual em geral. Como dito acima, diversos elementos entram no cálculo do particular ao realizar sua proposta, sem que, por isso, vá transformar esse cálculo em uma cláusula expressa. Nem por isso, tal fato deixa de ser previsível. A posição de Justen Filho deve ser aceita apenas parcialmente, na medida em que efetivamente não é conveniente, em termos de negociação, explicitar todos os aspectos que poderiam afetar o contrato. Sua conclusão, porém, que autoriza a revisão do contrato para readequação da equação financeira, é que deve ser vista com maiores reservas.

\subsubsection{Considerações sobre a jurisprudência acima analisada}

Da análise anteriormente efetuada, depreende-se que a jurisprudência recente que trata de contratos sujeitos ao $\mathrm{CDC}$ e ao regramento administrativo, embora necessariamente deva se vincular a pressupostos distintos dos aplicáveis aos contratos submetidos à disciplina do Código Civil, ainda adota como pano de fundo de suas considerações a teoria da imprevisão. A questão da alocação de riscos no contrato é dificilmente abordada, fazendo que a operação econômica subjacente ao contrato tenha seus contornos reiteradamente desconsiderados.

Sempre ressaltando a diversidade entre os regimes jurídicos relativos às relações de consumo e administrativas em relação às puramente privadas, entre entes em situação de igualdade jurídica, fica-se com a impressão que inexiste consideração precisa dos pressupostos fáticos e requisitos legais de aplicação da teoria da onerosidade excessiva sob qualquer das perspectivas analisadas. Paradoxalmente, ao contrário da experiência italiana, em relação a que Mario Bessone ${ }^{218}$ identifica resistência dos juízes à aplicação das normas sobre onerosidade para evitar "o perigo de que o juiz assuma a aparência de legislador" (tradução nossa) e a preocupação dos julgadores em não prejudicar a segurança do tráfico, a jurisprudência brasileira parece caminhar em direção oposta, sem, pelo menos expressamente, levar em consideração os efeitos de sua orientação sobre a economia, especialmente no que toca à segurança jurídica.

\footnotetext{
${ }^{218}$ Bessone, M. Adempimento e Rischio Contrattuale. Milão, Giuffrè, $2^{\mathrm{a}}$ reimpressão inalterada, 1998, pp. 75;
} 
Alguns dos acórdãos analisados dão a entender que os julgadores sentem-se investidos da função de redistribuição de riquezas, pensando o contrato menos como "veste" de uma operação econômica, ou então cumprimento estrito de uma promessa, e mais como meio de mitigação de desigualdades sociais. Embora não seja o objetivo deste trabalho estudar eventuais funções redistributivistas do ordenamento civil, a análise demonstra ainda ser necessário o empreendimento de esforço de síntese dialética entre a anterior situação de rigidez do vínculo contratual e atual possibilidade de flexibilização desse vínculo. 


\section{A PERSPECTIVA DA ANÁLISE ECONÔMICA DO DIREITO}

A revisão ou resolução do contrato por onerosidade excessiva não tem por fundamento os princípios de eqüidade ${ }^{219}$, boa-fé, ou função social do contrato, embora esses princípios conformem o quadro de sua aplicação, sob a perspectiva do vigente Código Civil.

A teoria da onerosidade excessiva antes deriva da longa elaboração histórica que se inicia com a noção do contrato como criador de um vínculo indissolúvel, quase sagrado - daí a reveladora expressão "santidade dos pactos". Essa elaboração transformadora culmina, na era industrial e pós-industrial, em contratos extremamente complexos, como os de engineering, que são parte de uma realidade econômica sempre dinâmica e globalizada. Nesse sentido, contratos complexos, atualmente, têm caráter internacional mais ou menos acentuado, mas raramente deixam de tê-lo. Ainda que as partes não se submetam a jurisdições diversas, o objeto contratual, os bens ou serviços transacionados dificilmente deixam de ter elementos originados em mais de um país.

Embora pontualmente possa-se identificar a regra moral da santidade dos pactos em alguns aspectos do processo de formação, execução e conclusão de um contrato complexo, em geral, é justamente a multiplicidade de fatores envolvidos em sua execução contratual que torna superada a aplicação irrestrita do princípio pacta sunt servanda. Como visto anteriormente, a execução de contratos de engineering envolve incertezas e riscos, cuja origem vai desde a falta de informação sobre elementos da natureza (o solo, por exemplo), insumos e tecnologias empregadas; ou mesmo variações inesperadas desses elementos. Se a fabricação em escala ou em linha de produção é notoriamente sujeita a menor variabilidade em relação a quantidades e tipos de insumos utilizados, a obra complexa, única, singular e sobretudo inovadora revela grande variedade de elementos constituintes e grande interação entre eles.

${ }^{219}$ Fonseca, A. M; Caso Fortuito e Teoria da Imprevisão, Forense, Rio de Janeiro, $3^{\mathrm{a}}$ ed., 1958, p. 244. 
Por exemplo, ainda que seja perfeitamente possível estimar com acuidade o número de horas de trabalho humano e insumos materiais necessários à construção de um metro quadrado de parede, não se pode estimar com precisão se esta medida unitária será a mesma quando se pensa que, em uma obra complexa, paredes se conectam entre si de maneira singular, para suportar cargas não usuais e sujeitas a fatores que não são comumente encontrados. Pense-se numa usina nuclear, a título de ilustração, que tem paredes blindadas para fins de eventual isolamento de áreas expostas à radioatividade.

Por outro lado, é fato que o empreiteiro - como, aliás, as pessoas em geral, porém de maneira intuitiva - formula os preços que propõe ao dono da obra com base em estatísticas e previsões. Ao contrário do que ocorre com a produção industrial e em escala, a possibilidade de estocagem de insumos, no engineering, é limitada (homenshora não são insumos estocáveis, por exemplo), a tecnologia construtiva é muita vezes nova e a interação entre obra e meio ambiente é delicada. Essas circunstâncias fazem com que a execução do contrato de engineering se desenvolva em ambiente de risco, como visto.

Ao contrário da compra e venda e outros tipos contratuais, é possível dizer que o empreiteiro luta contra as ocorrências fortuitas e vai gradualmente confirmando suas expectativas no curso da execução do projeto, a ponto de Lessard e Miller ${ }^{220}$, em aprofundado estudo sobre grandes obras de engenharia, dizerem que:

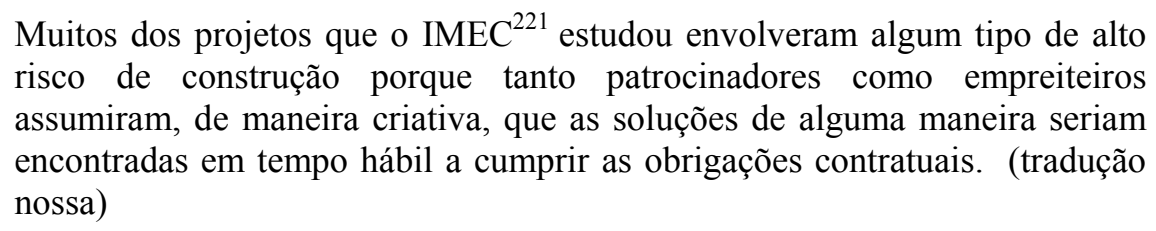

Em outras palavras, o empreiteiro, o engenheiro e muitos dos envolvidos em projetos de engenharia tomam decisões com base em estatísticas e

\footnotetext{
${ }^{220}$ Lessard, D. e Miller, R.; Mapping and Facing the Landscape of Risks”, in The Strategic Mangement of Large Engineering Projects - Shaping Institutions, Risks and Governance, ed. e Miller, R e Lessard, D., The MIT Press, Cambridge, 2000, p. 81

221 International program on the Management of Engineering and Construction projects, programa coordenado pela cadeira HQ/CAE de Administração de Tecnologia da Universidade de Québec, Montreal, Canadá. A cadeira é dirigida pelo Prof. Roger Miller (http://www.er.uqam.ca/nobel/r34670/anglais1.html ultima visita em 01.12.2006)
} 
probabilidades. Reitere-se, porém, que as estatísticas e decisões são instrumentos de tomada de decisão, mas estão longe de ser antecipações da realidade efetiva, uma vez que entre a tomada da decisão e a execução existe o tempo, que traz a contingência. Em passagem que resume bem algo que é senso comum, Luhmann diz que:

\begin{abstract}
O cálculo probabilístico tem sido frequentemente usado num esforço de prover o presente com uma base consensual sobre que decisões podem ser tomadas. No entanto, esse cálculo falha precisamente nessa função, precisamente do ponto de vista social. Isso se torna aparente na representação de probabilidades na dimensão temporal ou espacial. Mesmo que alguém saiba que uma usina nuclear explode uma vez a cada doze milhões de anos, pode, todavia, acontecer de explodir amanhã. Mesmo que alguém saiba que se sofre um acidente fatal dirigindo numa rodovia uma vez a cada doze milhões de quilômetros, a morte pode ainda estar esperando na próxima curva. Na avaliação social, o cálculo deixa todas as eventualidades abertas para o caso individual e a avaliação do risco diferirá naturalmente dependendo de se alguém sente que o acidente poderia ocorrer muito cedo ou provavelmente somente ao final de um período inteiro ${ }^{222}$ e 223 .
\end{abstract}

Assim, o cálculo probabilístico nada garante para o futuro, mas, como diz Luhman, é usado como base consensual para a tomada de decisões. Essa base consensual se consubstancia, geralmente, no contrato. Ou seja, o contrato de engineering assim como o contrato de seguro e outros contratos que envolvam álea em alguma medida - trazem em seu núcleo o juízo sobre probabilidades que, por mais acuradas que sejam, ou que revelem o menor nível de risco possível, ainda assim podem se converter em prejuízo, em dano.

Por essa razão, o artigo 478 do Código Civil parece não ter a profundidade de percepção desses característicos dos contratos complexos, como os contratos de engineering, ao condicionar a revisão ou resolução do contrato por onerosidade excessiva somente "em virtude de acontecimentos extraordinários e imprevisíveis". A extraordinariedade de determinado evento, em muitos contratos de

\footnotetext{
${ }^{222}$ Luhman, N. op. cit. p. 49

${ }^{223}$ Como ilustração entre o descompasso entre probabilidades e modelos computacionais em áreas muito afetas ao contrato do engineering, como a constrição de túneis, vide o comentário de Duddeck, H., reproduzido po Lessaman H. e Vieder, R; The Implications of Geotechnical Model Uncertainty for Construction Mangement, in Analysing Uncertainty in Civil Engineering, Springer-Verlag, Heidelberg, 2005, p. 171:

The entire discussion in the regulations about safety coefficients and probabilities ignores the much more important question: how do we even find the potential risk and how can we estimate them correctly? In underground construction in particular, it becomes apparent that the computed safety is not the most important thing, but that which comes before, namely the hazardous situations to which attention must be paid.
} 
engineering, é de difícil qualificação como tal, tendo em vista que muitos projetos empregam novas tecnologias e, por se tratarem de contratos negociados individualmente, muitas vezes não incluem provisões que correspondam ao nível de risco encontrado durante a execução do contrato.

Se alguns ordenamentos civis, como os que seguem a tradição francesa, por exemplo, optam pela resolução do contrato em caso de conflito entre as partes, outros, como o BGB, estendem o leque de opções disponíveis às partes em caso de conflito. Na Alemanha, além da resolução e da possibilidade de revisão do contrato em caso de alteração das circunstâncias, também são adotadas políticas legislativas que restringem as hipóteses de conflito com a adoção de teorias como a do adimplemento substancial. Com efeito, na disciplina alemã dos contratos de obra - Werkwertrag - tipo equivalente ao nosso contrato de empreitada, prevê-se, no inciso (1) do $\S 640$ do BGB, que o dono da obra não pode recusar-se a recebê-la em vista da existência de defeitos não essenciais $^{224}$.

Em caso de conflito insolúvel, a resolução contratual constitui uma "opção de saída" 225 do jogo contratual para qualquer das partes que se considere prejudicada. Assim, colocada a resolução do contrato como a espada que paira sobre cada uma das partes em caso de descumprimento contratual, é necessário saber até que ponto as partes têm capacidade econômica para suportar variações no programa

${ }^{224}$ BGB, § 640, (1) (in Codice Civile Tedesco - Bürgerliches Gesetzbuch. Trad. Patti, S., Milão, GiuffréBeck, 2005, p. 458-9)
\$640 Abnahme
(1) Der Besteller ist verpflichtet, das vertragsmäßig hergestellte Werk abzunehmen, sofern nicht nach der Beschaffenheit des Werkes die Abnahme ausgeschlossen ist. Wegen unwesentlicher Mängel kann die Abnahme nicht verweigert werden. Der Abnahme steht es gleich, wenn der Besteller das Werk nicht innerhalb einer ihm von Unternehmer bestimmten Frist abnimmt, obwohl er dazu verpflichtet ist.
Tradução para o italiano:
$\S 640$ Presa in consegna
(1) II committente e obbligato a prendere in consegna l'opera realizzata in conformità al contratto, ameno che Ia presa in consegna sia esclusa dalle caratteristiche dell'opera. La presa in consegna non può essere rifiutata a causa di difetti non essenziali. Alla presa in consegna e equiparato il caso il cui il committente non prende in consegna l'opera entro un termine congruo fissatogli dall'imprenditore, sebbene sia obbligato a farlo.

${ }^{225}$ Baird, D. G et al,; Game Theory and The Law, Harvard University Press, Cambridge, 1994, p. 307: "Exit option: The right of one player to terminate a bargaining game and receive some alternative payoff." 
contratual que passam a ser possibilitadas pelo reconhecimento da situação de onerosidade excessiva, com a conseqüente potencialidade de revisão do contrato pelo juiz ${ }^{226}$.

Obviamente, essa avaliação somente pode ser feita tomando-se em consideração o contrato isoladamente das demais relações jurídicas mantidas pelas partes. Do contrário, o direito contratual estaria sendo aplicado com intuito redistributivo.

Mas, para que o juiz possa atuar sobre a relação afetada por contingências imprevistas, é necessário conhecer como, do ponto de vista econômico, as partes chegaram ao acordo consubstanciado no contrato e como a alteração inesperada da situação de contorno do contrato afeta sua execução. Muito do que será dito doravante decorre de elaboração empreendida para subsidiar a interpretação da onerosidade excessiva a partir de artigo de Triantis "Unforeseen contingencies. Risk Allocation in Contracts"227, que justamente revê a literatura existente sobre as doutrinas da common law que lidam com a alteração inesperada de circunstâncias tendo como pano de fundo a análise desenvolvida pela análise econômica do direito a partir da alocação de riscos no contrato.

Em contratos como os de engineering, uma vez definido o escopo contratual, que constitui o objetivo a ser alcançado pelo esforço conjunto das partes - que intercambiarão prestações e contraprestações - põe-se o problema básico da formação contratual, que consiste na alocação de riscos entre as partes, como visto no Capítulo 3.2, acima.

Essa fase de início do iter contratual determina, do ponto de vista contratual, o nível de investimento que cada uma das partes destinará à execução do contrato. A noção é intuitivamente compreensível na medida em que, para o agente racional, quanto maior o risco suportado, maior a remuneração esperada. Nesse contexto, por "preço" do risco, deve-se entender tanto o valor da prestação exigida pelo empreiteiro para suportar os riscos que assume no contrato, como o ônus que o dono da obra terá para, ele próprio, suportar o risco assumido. Exemplificando com hipótese frequentemente encontrada em contratos de engineering, o empreiteiro certamente exigirá ser remunerado

\footnotetext{
${ }^{226}$ Vide artigo 317 do Código Civil.

227 Triantis, G. in Encyclopedia of Law and Economics - Volume III - the Regulation of Contracts, Bouckaert, B e De Geest, G, ed.; Edward Elgar Pub. Ltd, Cheltenham, 2001 (reimpressão).pp. 100-116)
} 
com certo valor por suportar o risco do solo em que se erigirá a obra. Da mesma forma, caso o dono da obra opte por assumir esse mesmo risco, arcará com os custos respectivos, como os de execução de sondagens, pagamentos de acréscimos ao empreiteiro para fazer frente a eventuais dificuldades de solo e assim por diante.

Assim, partindo-se do pressuposto, também racional, de que as partes cheguem a acordo quanto ao preço a ser pago pelo conjunto de riscos que cada uma suporta, cada uma delas, partes, determinará o nível de investimento necessário a suportar esses riscos. Empreiteiro ou dono da obra, no exemplo citado fará as sondagens que considere necessárias, planejará o emprego de equipamentos mais ou menos pesados etc.

No entanto, do ponto de vista da eficiência econômica, as partes tenderão a assumir os riscos em relação a que estejam mais preparadas a suportar. Sempre voltando ao exemplo citado, embora, em muitos casos, o dono da obra, ainda na fase de estudos de viabilidade de projetos, faça sondagens de solo e se disponha a assumir o risco do solo frente ao empreiteiro, por já ter realizado o investimento previamente, o detentor desse risco, em última instância, é usualmente a parte que tenha conhecimentos técnicos de geologia ou engenharia. No Brasil, geralmente, o próprio empreiteiro assume o risco ao final da obra, tendo em vista o que dispõe o artigo 618 do Código Civil a respeito da responsabilidade qüinqüenal pela segurança e solidez na empreitada de edifícios ou outras construções consideráveis ${ }^{228}$.

Ainda que seja possível dizer que o preço quantifique todo o espectro de direitos, riscos e obrigações das partes no contrato oneroso, no processo de

\footnotetext{
${ }^{228}$ Por escapar ao objeto deste estudo, não se entrará aqui na discussão a respeito da eficácia cogente ou dispositiva da responsabilidade pela solidez e segurança do edifício especificamente em caso de problemas no solo. No entanto, a título de ilustração, mesmo que se considere que o empreiteiro necessariamente responde pela solidez e segurança do edifício, quando a origem de eventual defeito ou dano derive de problemas de solo, o dono da obra pode, ainda assim assumir o risco quanto às contingências relativas ao solo durante a execução da obra. Ou seja, se durante a execução da obra o solo se mostrar com característicos diversos dos pressupostos pelas partes, conforme o contrato, o preço poderá ser revisto. Depois de concluída a obra, no entanto, o risco seria assumido pelo empreiteiro. Essa interpretação parece ser razoável na medida em que o empreiteiro estaria em melhor posição para responder por defeitos ocasionados por falhas de solo porque, além de seu conhecimento técnico, ao executar a obra teve a oportunidade de se inteirar diretamente sobre os característicos geológicos da área. A esse respeito, vale reproduzir este trecho de Lessaman H. e Vieder, R.: "A responsible site engineering will always (not just in the event of failure) want to know how the building system will behave in the vaious phases of construction and what has been assumed as being the cause of a particular failure pattern." The Implications of Geotechnical Model Uncertainty for Construction Mangement, in Analysing Uncertainty in Civil Engineering, Springer-Verlag, Heidelberg, 2005, p. 166
} 
alocação de riscos pode-se levar em conta a classificação dos riscos sob o ponto de vista quantitativo ou qualitativo, como visto acima. É possível, em novo exemplo, que risco de problemas de solo acima sejam tomados pelo empreiteiro, durante a fase de execução da obra, até certo montante (alocação quantitativa), além da qual seria suportado pelo dono da obra; ou então, que certo tipo de risco relativo ao solo, como os relativos ao lençol freático, fosse suportados pelo dono da obra e, outro, como o risco relativo à consistência do solo fosse deixado para o empreiteiro.

Nesse ponto, abrem-se parêntesis para lembrar que é de vital importância no tema da alocação dos riscos contratuais a técnica da limitação de responsabilidade, além das questões técnicas, econômicas, relativas ao preço e a definição do objeto contratual. A técnica da limitação da responsabilidade constitui uma das respostas jurídicas ao problema da alocação de riscos. A questão, proverbialmente debatida no Brasil $^{229}$, não foi inteiramente resolvida no Código Civil como o foi no BGB que, em seu $§ 639$ dispôs o seguinte ${ }^{230}$ :

\section{§ 639 Haftungsausschluss \\ Auf eine Vereinbarung, durch welche die Rechte des Bestellers wegen eines Mangels ausgeschlossen oder beschränkt werden, kann sich der Unternehmer nicht berufen, wenn er den Mangel arglistig verschwiegen oder eine Garantie für die Beschaffenheit des Werks übernommen hat.}

\section{§ 639 Esclusione della responsabilità}

L'imprenditore non può avvalersi di una pattuizione mediante la quale vengono esclusi o limitati $i$ diritti del committente in conseguenza d un difetto, qualora egli abbia taciuto dolosamente il difetto oppure abbia assunto una garanzia per le caratteristiche dell'opera.

${ }^{229}$ Vide Aguiar Dias, J., Cláusula de Não-Indenizar, Forense, Rio de Janeiro, $4^{\mathrm{a}}$ ed. 1980, e sobretudo, seu Da Responsabilidade Civil, Forense, Rio de Janeiro, 9a ed.1994, vol. II, p. 672 , em que cunhou a sempre citada frase: "Nosso direito não simpatiza com as cláusulas de irresponsabilidade".

${ }^{230}$ BGB, § 639; Codice Civile Tedesco - Bürgerliches Gesetzbuch. Trad. Patti, S., Milão, Giuffré-Beck, 2005, p. 458-9. Vide, também, nas Conditions of Contract for EPC/Turnkey Projects, Genebra, FIDIC, $1^{\mathrm{a}}$ ed. 1999, p. 47:

Neither Party shall be liable to the other Party for loss of use of any Works, loss of profit, loss of any contract or for any indirect or consequential loss or damage which may be suffered by the other Party in connection with the Contract, other than under Sub-Clause 16.4 [Payment on Termination] and Sub-Clause 17.1 [indemnities].

The total liability of the Contractor to the Employer, under or in connection with the Contract other than under Sub-Clause 4.19 [Electricity, Water and Gas], Sub-Clause 4.20 [Employer's Equipment and Free-Issue Material, Sub-Clause 17.1 [indemnities] and Sub-Clause 17.5 Intellectual and Industrial Property Rights], shall not exceed the sum stated in the Particular Conditions or (if a sum is not so stated) the Contract Price stated in the Contract Agreement. This Sub-Clause shall not limit liability in any case of fraud, deliberate default or reckless misconduct by the defaulting Party. 
Embora não diga respeito diretamente a este trabalho, a técnica da limitação convencional da responsabilidade possui importantíssima função na alocação de riscos, sobretudo se se levar em conta o princípio de que cabe à parte melhor preparada assumir determinado risco. Como já visto em capítulo anterior, a identificação do superior risk-bearer só se pode dar caso a caso, no contrato, em vista das capacidades e habilitações das partes e da rede de interesses que circunda o contrato.

O problema que se põe é que a alocação de riscos nos contratos de engineering está muito longe de ser um procedimento simples, como visto acima. Não há pessoa que lide com contratos que duvide de que, quanto mais claro o significado de suas disposições, quanto mais definida a repartição de riscos e contrapartidas, "melhor é o contrato". Independentemente de técnicas, estilos ou tradições de redação de contratos, quanto mais hipóteses possíveis de ocorrências futuras são cobertas pelo contrato, mais claramente os riscos estarão identificados e alocados no programa contratual, com a conseqüência da melhor exploração das capacidades das partes.

Ainda que os valores que orientam a decisão do juiz ou árbitro possam ser sociais, por exemplo, a manutenção do contrato em vista de seus efeitos em relação a terceiros, como no caso de uma obra de infra-estrutura, o critério de preenchimento semântico para verificação da ocorrência da onerosidade excessiva pode ser encarado sob o prisma econômico, isto porque a matéria também diz respeito a custos de transação e à eficiência alocativa de recursos. O raciocínio baseia-se no enfoque de Williamson a respeito dos benefícios decorrentes da combinação Direito, Economia e Organizações para o estudo dos contratos:

Então, qual o benefício trazido pela adoção de um enfoque concebido de
modo a combinar Direito, Economia e Organizações para o estudo dos
contratos? Tal como eu vejo, o maior alcance decorre do uso diligente da
perspectiva que a Economia dos Custos de Transação transmite. A análise
dos contratos incompletos no seu conjunto será facilitada pela superação do
conceito acadêmico do contrato como regra jurídica pela perspectiva do
ordenamento privado e pelo questionamento sobre os mecanismos através
doa quais se logra economizar em custos transacionais.

${ }^{231}$ Williamson, Oliver; Por que Direito, Economia e Organizações?, in Zylbersztajn, Décio e Sztajn, Rachel; Direito \& Economia - Análise Econômica do Direito e das Organizações, Editora Campus-Elsevier, Rio de Janeiro, 2005, p. 46-47. 
Entretanto, a Análise Econômica do Direito expõe ser teoricamente improvável a descrição pormenorizada no contrato de todas as hipóteses possíveis de ocorrências futuras em vista dos custos de transação envolvidos nesse procedimento. Esses custos de transação, diz Tirole ${ }^{232}$, geralmente são relacionados pela literatura a três fatores:

a. Contingências imprevistas: "As partes não são capazes de definir ex ante as contingências que podem ocorrer (ou as ações que podem ser viáveis) posteriormente. Assim, devem se contentar em assinar o contrato, como uma relação de autoridade ${ }^{233}$ ou patrimonial, que não mencione explicitamente essas contingências, ou com não assinar contrato algum";

b. Custo de redigir de contratos: "Mesmo que alguém pudesse prever todas as contingências, estas seriam tão numerosas que seria demasiadamente custoso descrevê-las no contrato";

c. Custo de execução judicial ou arbitral de contratos: "Os juízes devem entender os termos do contrato e verificar as contingências e ações contratadas para fins de executar o contrato". (tradução nossa)

Considerando-se que os fatores acima enumerados são autoexplicativos, é necessário esclarecer que o custo de executar judicialmente contratos, para a Teoria dos Contratos Incompletos, não tem como foco de atenção os custos de execução em si, como os honorários de advogado e custas judiciais, mas sim que "se é

232 Tirole, J., Incomplete Contracts: Where do we stand?, Econometrica, vol. 67, no 4 (julho/1999) pp. 743744. A tradução acima é do seguinte texto:

Unforeseen contingencies: "Parties cannot define ex ante the contingencies that may occur (or actions that may be feasible) later on. So, they must content themselves with signing a contract such as an authority or ownership relationship that does not explicitly mention those contingencies, or with signing no contract at all.',

Cost of writing contracts: "Even if one could foresee all contingencies, they might be so numerous that it would be too costly to describe them in a contract." Cost of enforcing contracts: "Courts must understand the terms of the contract and verify the contracted upon contingencies and actions in order to enforce the contract."

${ }^{233}$ Vale esclarecer que a Teoria dos Contratos Incompletos também é aplicada pelos economistas a várias relações, inclusive as não patrimoniais, estendendo o conceito de "contrato" a relação de subordinação como a relação entre agências reguladoras e administrados. 
suficientemente grande o custo de prover ao juiz prova de que uma contingência ou condição relevante ocorreu, então a inclusão de uma disposição a respeito [no contrato] não é compensadora para as partes" ${ }^{\text {234 }}$. De outro lado, esse terceiro fator também se liga à hipótese de ser, na prática, impossível, ou muito custosa, a efetiva verificação da ocorrência de certas contingências pelo juiz ${ }^{235}$.

Por oposição, um contrato seria considerado "completo", segundo a Teoria dos Contratos Incompletos, quando previsse todas as condutas, prestações e contraprestações relativas às partes em todas as hipóteses relevantes para o contrato $^{236}$.

No campo da engenharia de alta complexidade, a presença dos ditos contratos incompletos é extremamente freqüente. A própria citação de Lessard e Miller, acima transcrita, mostra que, muitas vezes, em grandes obras, as soluções para os problemas construtivos que se apresentam são encontradas no curso da própria obra - e não planejadas de antemão. Especialmente quando se trata de contratos tendo por objeto obra cuja solução tecnológica de viabilização não é clara ou o pouco desenvolvida, a incompletude contratual é substancial. É freqüente que contratos que partem de projetos básicos arquitetônicos - por envolverem complexas tecnologias de engenharia em sua execução - ainda não contem com a técnica construtiva totalmente desenvolvida de antemão. Se, como visto acima, uma das maneiras de contornar essa incompletude é a correta alocação de riscos, com a adoção de subtipos contratuais como o contrato por administração, por exemplo, também é certo que, em muitos casos, esse subtipo não é admissível para órgãos financiadores ou mesmo partes privadas, dadas as limitações orçamentárias e mesmo de retorno esperado.

\footnotetext{
${ }^{234}$ Shavell, S.; Foundations of Economic Analysis of Law, o. cit., p. 300.

${ }^{235}$ Imagine-se, por exemplo, que o solo onde a obra é executada seja contaminado no curso da construção, exigindo providências imediatas do empreiteiro de tal sorte que os vestígios de contaminação desapareçam e, portanto, seja impossível, na fase judicial, provar a causa da contaminação. Embora uma visão mais apressada possa considerar que o risco da obra, antes de sua entrega, é do empreiteiro, este pode ter se eximido, contratualmente (ou seja, transferido ao dono da obra) dos riscos do caso fortuito e força maior e vir a alegar que a contaminação se deu por culpa de terceiro, ou até mesmo por culpa ou responsabilidade do dono na obra (imagine-se um canteiro de obras em que várias construções são desenvolvidas ao mesmo tempo, por empreiteiros diversos, como, por exemplo, uma grande unidade de produção de celulose). Claramente, estaria criado impasse de difícil solução.
}

${ }^{236}$ Com adaptações, esta é a definição de Schwartz, A., verbete Incomplete Contracts, The New Palgrave Dictionary of Economics and the Law, Palgrave Macmillan, 2002, vol. 2, p. 277: "A complete contract describes payoff-relevant actions for every possible state of the world and the payoffs for these actions." 
A Teoria dos Contratos Incompletos não tem sido empregada sob a perspectiva da interpretação dos contratos, já que, segundo Shavel1 ${ }^{237}$, "a premissa geral na literatura da contratação incompleta é a de que os contratos são [judicialmente] executados como escritos, de maneira que a interpretação dos contratos não é examinada" (tradução nossa). Ela constitui antes um modelo de análise da alocação de riscos inscrita no contrato desenvolvida pela Análise Econômica do Direito. Sob sua própria perspectiva, a do Direito Contratual, vários códigos e compilações civis subjacentemente reconhecem a incompletude do contrato. São exemplos já citados: a adoção da teoria da onerosidade excessiva no Brasil, nos artigos 478 a 480 (parte geral dos contratos) e 625, inciso II (empreitada) do Código Civil; na Itália, artigos 1.467 e 1.468 do Código Civil italiano de 1942; da teoria da alteração das circunstâncias negociais, na Alemanha, § 313 do BGB; e nos Estados Unidos, com o § 2-615 do Uniform Commercial Code, e mesmo as teorias da "impracticability" e "impossibility" consolidadas nos "Restaments of Contracts".

Entretanto, embora a Análise Econômica do Direito venha considerando que a incompletude contratual seria um suposto fático dos contratos, Hermalin, Katz e Craswell ${ }^{238}$ notam que esse suposto é de problemático reconhecimento já que a completude contratual pode, muitas vezes, ser forçosamente alcançada com a adoção de cláusulas que simplesmente dissessem algo como "se um evento (contingência), outro que aqueles enumerados acima, ocorrer, a conseqüência será...;",239 . Ou seja, é possível, do

${ }^{237}$ Shavell, S., On the Writing and the Interpretation of Contracts . Harvard Law and Economics Discussion Paper No. 445, out/2003., disponível em SSRN: http://ssrn.com/abstract=470100 ou DOI: $10.2139 /$ ssrn.470100 (consultado em 07.09.2006), verbis: More generally, the usual assumption in the incomplete contracting literature is that contracts are enforced as written, so that the interpretation is not examined.

${ }^{238}$ Hermalin, B. et al., The Handbook of Law and Economics, a ser editado, disponível em SSRN: http://ssrn.com/abstract=907678, visto em 15.09.2006, p. 65 .

${ }^{239}$ O texto é o seguinte:

The assumption of literally incomplete contracts has played an important role in law \& economics (both implicitly, as in Shavell, 1980, and Rogerson,1 984, and explicitly, as in Goetz and Scott, 1981, Ayres and Gertner, 1989, and Hadfield, 1994). Nonetheless, as Hermalin and Katz (1993) observe, it is a potentially problematic assumption, because it is so easy to complete contracts by adding a stereotypical residual ("none-of-the-above") clause to a contract. That is, literal completeness can be achieved simply by adding a clause that states, "if an event (contingency) other than those listed above occurs, then the outcome shall be ..." 
ponto de vista contratual, alocar riscos genericamente de forma a deixar certo contrato completo.

Os efeitos dessa incompletude sobre os contratos de engineering demonstram que o juiz poderá estar diante de uma situação em que as partes deliberadamente deixaram obscuro certo aspecto contratual a fim de que, em renegociação, ou por decisão de terceiros (o juiz), seja preenchida a lacuna (gap-filling procedure). Mais, diante do eventual comportamento oportunista de uma das partes, poderá o juiz verificar que não preencher a lacuna contratual poderá justamente significar a premiação do comportamento oportunista . Veja-se, por exemplo, a hipótese levantada por Shavell ${ }^{240}$, em que um construtor deliberadamente comprometeu-se a erigir uma fábrica para certo empresário, usando método construtivo que era mais caro que o necessário para a finalidade e cuja utilização não era de domínio de outros construtores. Em meio à construção, o construtor ameaça abandonar a obra se não houver acréscimo substancial do preço contratual, deixando refém o dono da obra-empresário. A hipótese descrita configura mais um hold-up problem ${ }^{241}$, portanto.

Coase , em 1937, publica o artigo The Nature of the Firm ${ }^{242}$, em que discute a coordenação dos agentes econômicos, contrapondo duas formas abstratas de coordenação: o mercado e a firma, e, como forma intermediária, o contrato. Essas formas de organização são empregadas na medida em que uma ou outra impliquem menores custos de transação, considerada a transação como a unidade de análise do sistema econômico. A partir desse insight de Coase, a literatura econômica, principalmente com os trabalhos de Oliver Williansom e Klein et al., passa a identificar as dimensões críticas de acordo com as quais os custos de transação diferem entre si, sendo a especificidade de ativos a principal delas. Como diz Paulo Furquim de Azevedo, "Se uma determinada transação implica investimentos que lhe são específicos - não podendo ser utilizados de

\footnotetext{
240 Shavell, Steven; Contracts, Holdup and Legal Intervention, paper para discussão, Internet (http://www.law.harvard.edu/programs/olin_center/)

${ }^{241}$ Vide nota $n^{\circ} 46$, acima, para a noção de holdup problem.

242 Economica, 4386 (1937), posteriormente republicado em "The Firm, the Market and the Law", The University of Chicago Press, Chicago, 1988, pp. 33-55.
} 
forma alternativa sem uma perda considerável - a parte que arcou com esses investimentos fica em uma posição especialmente sujeita a alguma ação oportunista das demais partes"243.

A literatura jurídica já tem se preocupado com o assunto ${ }^{244}$, embora de maneira errática, sendo certo que não existem parâmetros confiáveis para avaliar até que ponto a adaptação ou resolução do contrato mediante aplicação das normas sobre onerosidade excessiva premia o comportamento oportunista, ou realmente faz a adequação do conteúdo contratual às novas situações institucionais, inclusive frente à incerteza inerente ao investimento. É fato, porém, que, ausente o comportamento oportunista, a adaptação do contrato seria grandemente facilitada, com o alcance de soluções de mercado. No entanto, dada a complexidade do objeto do contrato de que se trata - o contrato de engineering - a identificação do comportamento impróprio é bastante difícil.

Em artigo publicado originalmente no Journal of Law, Economics, and Organization $^{245}$, Coase, comentando antigas anotações sobre o contrato como forma de

\footnotetext{
${ }^{243}$ Paulo Furquim de Azevedo, Capítulo 1, “Antecedentes - 1.6 Williamson, Klein et alii: dimensionalizando as transações, o papel da especificidade de ativos", p. 50, in Elizabeth M. M. Querido Farina et alii, “Competitividade: Mercado, Estado e Organizações', Editora Singular, São Paulo, 1997. Para interessante tipificação das razões por que os ativos podem ser considerados específicos, feita pelo mesmo autor, vale transcrever: "Os ativos podem ser específicos a uma transação por diversas razões. Algumas vezes, o produto ou os equipamentos utilizados na produção contêm algum atributo fisico relevante apenas para uma contraparte (especificidade fisica). É o caso de componentes de um automóvel, feitos por uma empresa de autopeças, que fora desenvolvidos especificamente para uma família de modelos de uma mesma montadora, não tendo o mesmo valor se comercializados com outras empresas. Também são relevantes os casos em que o tempo necessário para encontrar e negociar com um segundo contratante constitui um custo relevante, podendo haver perdas decorrestes da perecibilidade ou da ociosidade de ativos (especificidade temporal). Ativos podem também ser especificos se seu retorno, em decorrência de custos de frete, for maior se a transação for efetuada por uma contraparte localizada próximo (especificidade locacional). Finalmente, a especificidade de um ativo pode derivar de algum componente de capital humano, ou seja, capacitações e aprendizado incorporados às pessoas (especificidade humana), ou de um investimento realizado com uma única finalidade de atender à demanda de uma contraparte (ativos dedicados)" -"Contratos - Uma Perspectiva Econômica", Capítulo 6 - "Economia dos Contratos", p. 127, in Zylbersztajn, D. e Sztajn, R, Direito \& Economia, Campus - Elsevier, São Paulo, 2005.

${ }^{244}$ Roppo, Vincenzo; op.cit., p. 1041/2: "In generale, può dirsi che la risoluzione si presenta inidonea nei casi il cui il contratto serve a realizzare operazioni di lunga durata, tecnicamente complesse ed economicamente impegnative, che - una volta avviate - sono difficilmente reversibili. Si pensi agli appalti per grandi opere impiantistiche o infrastrutturali; o alla progettazione, fornitura, messa in funzione, manutenzione di un complicato sistema informatico per qualche grande organizzazione privata o pubblica: se anche sopravvengono problemi nel rapporto, è impensabile che la realizzazione della diga o della piattaforma petrolifera o del ponte sospeso sulla baia possa essere lasciata a metà, o proseguita da un'impresa diversa; né è pensabile che il sistema informatico (che oramai condiziona tutta la vita dell'organizzazione-cliente) venga smantellato e rifatto ex novo."
}

245 "Starting with the view that both integration and long-term contracts are ways of binding people and therefore reducing risk (the risk that they may act in a way disadvantageous to you), I asked why a certain 
organização, perguntou-se por que, em alguns casos, prefere-se a celebração do contrato de longo prazo, em lugar da integração vertical, tendo em vista que ambos - integração e contrato de longo prazo - são meios de vincular pessoas e reduzir riscos, particularmente porque, à primeira vista, todas as vantagens da integração podem ser obtidas por intermédio do contrato de longo prazo. Esse questionamento pode ser estendido aos contratos de engineering.

Por um lado, as partes entabulam contratos complexos de engineering por duas razões:

a) O desenvolvimento do objeto de um contrato de engineering muita vezes é um investimento específico, cujos recursos investidos não podem ser facilmente realocados dentro da firma - ou seja, não podem ser utilizados de forma alternativa sem perda considerável, já que a atividade-fim é diversa da de engenharia. Por exemplo: a dona de uma obra de engenharia industrial provavelmente não terá razões econômicas para manter indeterminadamente equipes de engenheiros de projeto e construção depois da conclusão da obra, porque terá que fazer investimentos específicos em capacitação e dispensa da equipe. No entanto, fosse o mercado perfeito e ausentes comportamentos oportunistas, seria possível rapidamente formar equipes e localizar fornecedores, bem como deles se desfazer. b) Ocorre que, existindo a possibilidade de comportamentos oportunistas, também é um investimento específico identificar quem é confiável, sendo essa tarefa mais facilmente atribuível a um só centro de imputação - a firma de engenharia - que se incumbiria de conhecer seus fornecedores, sua reputação e qualidade de seus serviços.

Assim, voltando à dicotomia posta por Coase, o contrato - forma organizativa intermediária - parece servir à congregação de elementos de mercado, já que a firma de engenharia empregaria recursos para evitar comportamentos oportunistas dentro da cadeia produtiva que encima e, concomitantemente, beneficiar-se-ia do mercado ao procurar fornecedores economicamente eficientes para fins de aumentar sua margem de lucro. A noção intuitiva subjacente ao acima descrito é que poderia ser mais caro para o

solution is adopted in some cases but not in others, particularly since at first sight it would appear that all advantages of integration can be obtained by means of a long-term contract." - Ronald Coase, The Nature of the Firm, 1. Origin, 2. Meaning, 3. Influence, Journal of Law, Economics, and Organization, vol. 4, pp. 3-47 (1988). reproduzido in The Nature of the Firm: Origins, Evolution, and Development (Oliver E.Williamson and Sidney G.Winter, eds, Oxford University Press, 1991). 
dono da obra reunir todos os elementos para a consecução desta última por sua conta e risco do que contratar uma empresa de engenharia que, por utilizar os fatores de produção envolvidos na obra de engenharia de forma mais eficiente, pode concluir a obra a custos relativamente inferiores aos que o dono da obra incorreria para a mesma empreitada e ainda se beneficiar da margem de lucro.

No entanto, contratos de longa duração envolvem riscos naturais à consecução de seu objeto, como, por exemplo, o risco de haver flutuações inesperadas no preço de certa matéria-prima, mas também riscos de ocorrência de comportamentos oportunistas - muitas vezes associados aos ditos "riscos naturais", já que se pode aproveitar um risco natural como oportunidade de ganhos superiores à mera neutralização dos efeitos da concretização do risco.

Nesse momento, o que a economia trata de "assimetria informacional" faz com que o dono da obra (ou o juiz, se chamado a intervir) tenha poucos instrumentos de identificação do comportamento oportunista e a aplicação da regra da onerosidade excessiva, com o reequilíbrio contratual, pode ser afetada. Ora, a tarefa do aplicador do princípio da manutenção do equilíbrio contratual durante a vida do contrato é relativamente simples quando se pode identificar a fonte do desequilíbrio e sua imprevisibilidade.

Uma vez mais retornando ao exemplo anterior, dada a abrupta elevação do preço de certa matéria-prima, basta conhecer as quantidades envolvidas na execução do contrato e o diferencial de preços para que se proceda ao reequilíbrio contratual. No entanto, suponha-se que a matéria prima não possua cotação de mercado confiável ou que vários fatores se aglutinem no desequilíbrio contratual reflexamente, por exemplo: a inesperada escassez de matéria prima haja causado não somente o aumento de seu preço, mas dificuldades para sua aquisição, demandando o dispêndio de energias do contratado para aquisição da matéria prima, ou adaptação de sucedâneos. Nesse passo, comportamentos oportunistas poderão ocorrer já que ao dono da obra (ou juiz) pode se tornar extremamente custosa a análise de todos os fatores envolvidos no desequilibro contratual.

Paradoxalmente, os mesmos artigos de lei acima citados, de vários ordenamentos que permitem a revisão ou resolução do contrato em caso de alteração das 
circunstâncias negociais fazem com que, potencialmente, todo contrato de duração seja incompleto. Ainda que se adotasse uma cláusula do tipo da mencionada por Hermalin, Katz e Craswell, a lei reintroduziria o elemento de incompletude contratual justamente ao abrir a possibilidade de renegociação contratual ou sua resolução nas hipóteses contempladas nas teorias chamadas de "revisionistas" 246 , incorporadas a vários ordenamentos, como visto acima.

Dessa forma, ao adotar alguma das teorias revisionistas do contrato, o ordenamento, em maior ou menor grau, abre a possibilidade às partes de invocar as normas que conduzem à revisão contratual independentemente de o contrato ser mais ou menos completo, no último sentido acima (em razão da inclusão de uma cláusula que o "feche" genericamente).. Essa constatação leva a que sempre exista a possibilidade de interferência do juiz na relação contratual que, diferentemente das partes - que avaliam a alocação de riscos do contrato ex ante - avalia essa mesma alocação ex post, ou seja, após a ocorrência de certa contingência imprevista. Ao mesmo tempo, ao abrir a possibilidade de acesso ao juiz para revisão do contrato em caso de alteração das circunstâncias negociais, o custo de levar a questão ao Judiciário pode compelir as partes a renegociar.

De fato, dois dos fatores que restringem a possibilidade de renegociação entre as partes são o aumento dos custos de renegociação à luz das novas informações disponíveis e o comportamento estratégico das partes (hold-up, conforme referido no Capítulo 3.2, anterior). Nesse ponto, é possível que a adoção das teorias revisionistas do contrato pelo ordenamento venha a contribuir para a ineficiência na alocação de recursos, na medida em que as parte se verão como que "coagidas" a renegociar, mesmo que a solução socialmente desejável fosse a resolução do contrato. Mais uma vez, hipóteses de verificação de condutas oportunistas serão criadas.

Considerados os aspectos acima, fica claro que os contratos de engineering, por suas características de alocação de riscos acima apontadas, serão afetados pela nova regra brasileira sobre a onerosidade excessiva, na medida em que o perfil de riscos e complexidade da operação econômica que veiculam poderá tender à criação de novos comportamentos oportunistas que aumentarão a sofisticação das questões postas

\footnotetext{
${ }^{246}$ Fonseca, A. M; Caso Fortuito e Teoria da Imprevisão, Forense, Rio de Janeiro, $3^{\text {a }}$ ed., 1958, p. 247.
} 
ante os juízes. Se considerarmos o padrão de decidibilidade dos conflitos em vista da onerosidade excessiva experimentado pela jurisprudência brasileira até o momento, conforme examinado no Capítulo 3.3, anterior, vemos que os todos os envolvidos na resolução de conflitos contratuais terão um longo caminho a percorrer. A essa altura, talvez, as incertezas geradas pelo novo sistema de revisão contratual sejam melhor equacionadas, no âmbito dos contrato de engineering, pelas cortes arbitrais especializadas, a exemplo do que ocorre nos países desenvolvidos. 


\section{CONCLUSÃO}

Demonstrou-se neste estudo que os contratos de engineering possuem contornos próprios que os levam a ser considerados tipos sociais, sendo-lhes aplicável o regime das empreitadas, muito embora as operações econômicas a eles subjacentes revistam-se de características que revelam sua complexidade e elevado grau de riscos. Por se referirem a obras ou projetos de grande porte, muitas vezes relacionados ao desenvolvimento das infra-estruturas locais, tais operações não só exigem decurso de tempo considerável para sua conclusão, como a coordenação e controle de inúmeros fatores, que estão em interação constante entre si e com o ambiente externo, demandando criatividade, organização cooperativa, tecnologia e pesados investimentos financeiros.

A resposta jurídica para a veiculação dessas operações, de maneira a induzir os investimentos financeiros e humanos necessários e a cooperação entre as partes, tem sido a elaboração de minutas contratuais também complexas, cuja sofisticação se beneficia do desenvolvimento de contratos-tipo, ou formulários. Estes, em alguns dos países desenvolvidos, consolidam a experiência que vem sendo acumulada durante décadas e auxiliam as partes no planejamento de suas ações de médio e longo prazo tendentes à conclusão de obras em geral de grandes proporções. Procura-se, a partir da experiência acumulada e da consolidação de práticas reiteradas, reduzir os custos de prever o maior número de estados futuros e de negociar sobre a multiplicidade de questões incidentes. Em outras palavras, o esforço se destina a facilitar o tráfico negocial e reduzir custos de transação.

Todo esse esforço de consolidação de práticas e experiências, que aumenta a fluidez e eficiência do processo de negociação e execução contratual, tem por suposto que as regras acordadas para fazer frente às circunstâncias imprevistas sejam cumpridas, sob pena de se perder todo ou grande parte do esforço empreendido no planejamento das ações futuras. Ao planejar, alocam-se riscos e recursos, distribuem-se tarefas e se procura alcançar o equilíbrio entre as partes, a fim de permitir o desenvolvimento das obras em bases de cooperação. 
No entanto, a experiência demonstra que a cooperação é frequentemente substituída pelo oportunismo e o longo período de execução do contrato induz o surgimento de novas contingências que podem por em jogo o equilíbrio inicialmente estabelecido. No caso das grandes obras ou projetos, por mais que o esforço de planejamento engendrado por intermédio do contrato seja compensador, dificilmente será completo, exaurindo todas as hipóteses possíveis, justamente pela complexidade e nível de incertezas que se apresentam.

Assumindo-se que a completude contratual é utópica, os ordenamentos jurídicos viram-se na premência de flexibilizar o contrato, torná-lo adaptável às novas contingências e passaram a prever a possibilidade de que os contratos fossem revistos ex post, ou seja, após o estabelecimento da relação com a alocação de riscos e responsabilidades. Com isso, os ordenamentos buscaram o restabelecimento do equilíbrio inicialmente alcançado por intermédio da interferência de um terceiro desinteressado: juiz, árbitro ou autoridade reconhecida pelas partes no âmbito de sua relação. A relação antes bilateral torna-se tríplice e, como se expôs, o terceiro exerce seu poder sobre as partes - a quem realmente interessam os benefícios que podem advir do contrato (ou mesmo de sua resolução).

Paradoxalmente, ao se abrirem as portas do ordenamento contratual para a intervenção do juiz ou árbitro sobre o programa contratual, novos custos são incorridos e, a prevalecer a tendência apontada de que ao juiz é conferido o poder de alterar a relação contratual - independentemente do consentimento de ambas as partes quanto à possibilidade da continuidade contratual - um novo desequilíbrio poderá ser gerado e novos custos incorridos. Desse ponto de vista, a Análise Econômica do Direito, como método de análise do fato social, mostra que, do ponto de vista da alocação eficiente de recursos, a relação contratual pode se tornar comprometida nessa hipótese.

O desfecho da análise empreendida neste trabalho leva a duas conclusões, considerado o ordenamento vigente e as características peculiares aos contratos de engineering:

Primeiro, do ponto de vista de política de resolução de conflitos, conclui-se que será necessária a adoção de nova ótica pelos juízes ou árbitros em relação aos 
contratos, a fim de dar peso à consideração do contrato como "veste" de uma operação econômica e, que como tal, tem seus pressupostos e é conduzida sob a expectativa de que as partes auferirão a utilidade objetivada, a custos compatíveis. Se não se pode considerar que as partes necessariamente agirão em estrita obediência às exigências do comportamento cooperativo, é preciso saber investigar e distinguir o eventual comportamento oportunista e as causas dos eventuais desequilíbrios, a natureza das contingências cujo desfecho levou ao desequilíbrio e os efeitos que o provimento jurisdicional ou arbitral trará aos terceiros que, de uma forma ou outra, sejam afetados ou tenham interesse no projeto ou obra. É preciso não esquecer que contratos de engineering, pelo porte e sofisticação da operação que veiculam, necessariamente afetam uma multiplicidade de sujeitos que circulam em seu raio de influência. Adicionalmente, é necessário identificar precisamente se a contingência já possui tratamento no programa contratual, uma vez que a solução prevista no contrato, mesmo que aos olhos do juiz pareça inadequada, faz parte de um equilíbrio mais amplo e complexo.

Segundo, do ponto de vista da Economia dos Contratos, ou seja, da análise das estratégias contratuais, é possível que a flexibilidade que o ordenamento procura incorporar quanto ao vínculo contratual seja internalizada ao contrato. Num mundo ideal, diante da materialização ou perspectiva de concretização de qualquer fato ou ato não necessário, bastaria que as partes acordassem que as perdas ou ganhos daí advindos seriam distribuídos na mesma proporção das utilidades que esperavam auferir quando da celebração do contrato. Inúmeros fatores não permitem essa situação idílica, no entanto. Essa circunstância, não obstante, não impede que as partes divisem e aperfeiçoem mecanismos de solução ou mitigação das conseqüências de conflitos no interior do próprio programa contratual. Exemplos dessas estratégias, que já são adotadas e podem ser ampliadas e aperfeiçoadas, consistem no pré-estabelecimento regras de processamento de demandas ("claims") por parte do empreiteiro, na manutenção de terceiros que acompanhem o desenvolvimento contratual, como os gerenciadores de projetos.

Enfim, o trabalho procura mostrar que a flexibilização do vínculo contratual no sentido da abertura de canais de revisão das posições contratuais, em relação aos contratos de engineering é, em si, eficiente. Mas o mesmo não ocorre necessariamente com a flexibilização imposta externamente à relação contratual, uma vez que o equilíbrio do contrato de engineering é complexo e a situação de risco freqüentemente encontrada 
demanda soluções que contemplem a globalidade dos interesses envolvidos e o complexo equilíbrio da operação. 


\section{REFERÊNCIA BIBLIOGRÁFICA}

AIA; The American Institute of Architects, - software AIA Contract Documents.

ALPA, G. e. VERRUCOLI, P., (coord.) Al Nuovi tipi contrattuali e tecniche di redazione nella pratica commerciale. Quaderni di Giurisprudenza commerciale, no.14, Milão: Giuffrè, 1978.

ALPA, G., Engineering: Problemi de Qualificazione e di Distribuzione del Rischio Contrattuale" in Nuovi Tipi Contrattuali e Tecniche di Redazione Nella Pratica Commerciale - Profili Compartitici - Quaderni di Giurisprudenza Commerciale, a cura de Piero Verrucoli, n. ${ }^{\circ}$ 14, Milão: Giuffré, , 1978.

ALPA, G.; FUSARO, A., I Contratti di Engineering, in Trattato di Diritto Privato, direto da Pietro Rescigno, vol . 11, tomo III, 2a ed., Turim: UTET, 2000.

ALVES, J. C. M., Direito Romano, v. II, 5a. ed., Rio de Janeiro: Forense, 1995.

ARANGIO-RUIZ, V.; Istituzioni di Diritto Romano, Nápoles: Casa Editrice Dott. Eugenio Jovene, 1994.

ARISTÓTELES., Da interpretação, trad. Bini, E. São Paulo, Edipro $1^{\mathrm{a}}$ ed; , 2005, pp. 89-93

ARNAUD, A. J., Critique de la raison juridique - 2. Gouvernants sans frontières Entre mondialisation e post-mondialisation, Paris: L.G.D.J., 2003.

Código Civil francês, acessado em 15.06.2006 disponível em: http://www.legifrance.gouv.fr/WAspad/UnCode?code=CCIVILL0.rcv

BACKHAUS, J. G., The Elgar Companion to Law and Economics. 2a. ed. Cheltenham: Edward Elgar, Publishing, 2005.

BAIRD, D. G. et. al., Game Theory and the Law, Cambridge, Harvard University Press, 1994.

BARCEllONA, P., Formazione e Sviluppo del Diritto Privato Moderno, Náploes, Jovene Editore, 1993. 
BELLANTUONO, G., I Contratti Incompleti nel Diritto e Nell'Economia, Pádua, CEDAM, 2000.

BELLEGARDE NUNES et al., capítulo sobre o Brasil do livro FIDIC-Na Analysis of International Construction Contracts, editor geral Knutson, R.; Kluwer Law International e International Bar Association, Haia, 2005, p. 1

BESSONE, D., Do Contrato - Teoria Geral, $3^{\mathrm{a}}$ ed ., Rio de Janeiro: Forense, 1987.

BESSONE, M., Adempimento e Rischio Contrattuale. Milão, Giuffrè, $2^{\mathrm{a}}$ reimpressão inalterada, 1998, pp. 1-2

BETTI, E., Teoria Generale delle Obbligazioni, vol. I, Milão, Giuffrè, 1953.

BETTI, E., Teoria generale del negozio giuridico, Nápoles, Edizione Scientifiche Italiane, reimpressão corrigida da $2^{\mathrm{a}}$ ed., 1994.

BGB, - Codice Civile Tedesco - Bürgerliches Gesetzbuch. Trad. Patti, S., Milão, GiuffréBeck, 2005, p. 458-9)

BIGIAVI, W., (coord.) I Contratti Atipici, tomo II, Turim: UTET, 1991.

BIGIAVI, W., (coord.). L'Engineering, La Joint Venture, I Contratti di Informatica, I Contratti Atipici di Garanzia (Giurisprudenza Sistematica Di Diritto Civile e Commerciale). Turim: UTET, 1991.

BOBBIO, N, Dalla struttura alla funzione - Nuovi studi di teoria del diritto, Milão, Edizioni di Comunità, 1977, p 63

BOGGIANO, A; International Standard Contracts - The Price of Fainess, Graham \& Troutman/Martinus Nijhoff, Dordrecht, The Neherlands, 1991, pp. 2-5.

BOGUS, S; MOLENAAR, K.; DIEKMANN E.. Concurrent Engineering Approach to Reducing Design Delivery Time; Journal of Construction, Engineering and Management, v. 131, (2005) pp. 1179 e 1185.

BOLTON, P.; DEWATRIPONT, M., Contract Theory, Cambridge: The MIT Press, 2005.

BOON, J. A.; GOFFIN, R, Les contrats «clé en main ». 2a. ed. Paris: Masson, 1987..

BOWER, D.; ASHBY, G.; GERALD, K.; SMYK, W., "Incentives Mechanisms for Project Success", Journal of Management in Engineering, Vol. 18, No. 1, 2002.

Bruner, P e O'Connor, Jr, P.; Bruner \& O'Connor on Construction Law, West Group, 2002, vol. 2, §5:1, pp. 11-13 
BRUNER, P. e O'CONNOR, JR, P.; Bruner \& O'Connor on Construction Law, West Group, 2002, vols. 1 a 7.

CAMILletTI, F., Profili Del Problema Dell'Equilibrio Contrattuale. Milão: Giuffré, 2004.

CARVALHO de MENDONÇA, J. X., Tratado de Direito Comercial Brasileiro, $4^{\mathrm{a}}$ ed, Rio de Janeiro, Freitas Bastos, 1947

CAVAllo BORGIA,., Il Contratto di Engineering, Pádua Cedam, 1992, p. 135, discutida, em conjunto com outras, no capítulo 3 ,

CÍCERO, MARCO TÚLIO, “De Oficiis” (“Dos Deveres”), São Paulo: Martins Fontes, 1999.

COASE, R., The Nature of the Firm, 1. Origin, 2. Meaning, 3. Influence, Journal of Law, Economics, and Organization, vol. 4, pp. 3-47 (1988). reproduzido in The Nature of the Firm: Origins, Evolution, and Development (Oliver E.Williamson and Sidney G.Winter, eds.), Oxford: Oxford University Press, 1991.

COASE, R., The Nature of the Firm; Economica, vol. 4 pp. 386 ss. (1937), posteriormente republicado em The Firm, the Market and the Law, The University of Chicago Press, Chicago, 1988.

COASE, R., Why Economics Will Change, comentários proferidos na Universidade de Missouri, Columbia, Missouri, em 4 de abril de 2002; Ronald Coase Institute em: http://coase.org/coaseremarks2002.htm

CÓDIGO CIVIL FRANCÊS; Louage d'ouvrage (ou contrat d'entreprise) -arts. 1710 ; $1779,3^{\circ}$; e 1787 a $1799-1$ -

http://www.legifrance.gouv.fr/WAspad/UnCode?code=CCIVILL0.rcv (acessado em 15.06.2006).

CÓDigo CIVIL ITALIANO, - Il Codice Civile Illustrato, Piacenza, Casa Editrice La Tribuna, 2006, organização Maggese, F. e Pepe, I

COMISSÃO ALEMÃ PARA ADJUDICAÇÃO E CONTRATOS (DVA), Fontes: http://www.wuw-anwaltskanzlei.de/Baurecht/Baurecht-VOB/baurecht-vob.html e http://www.jura.uni-marburg.de/zusatzqualifikationen/baurecht/dokumente/SkriptVOBundAGB2.doc ambos consultados em 16.12.06

COMPARATO, F. K., Obrigações de Meios, de Resultado e de Garantia, in Ensaios e Pareceres de Direito Empresarial, Rio de Janeiro, Forense, 1978.

COMPARATO, F., O Poder de Controle na Sociedade Anônima, Forense, Rio de Janeiro, $3^{\text {a }}$ ed., 1983, pp.83, 84-85. 
COSTANZA, M, Il Contratto Atípico, Milão, Giuffrè, 1981, pp. 273 e 274

COOTER, R.; ULEN, T., Law and Economics, $4^{\mathrm{a}}$ ed. Boston, Pearson Addison Wesley, 2004

COUTO E SILVA, C. V., Contrato de "Engineering”, Revista dos Tribunais vol. 685, nov/1992, pp. 29-40.

CRASWELL, R.., Two Economic Theories of Enforcing Promises, in Readings in The Theory of Contract Law, Peter Benson, ed., Cambridge University Press, 2001, disponível em SSRN: http://ssrn.com/abstract=243613 (consultado em julho 2000),

DE MARTINI, A.; L'Eccessiva Onerosità Nell'Esecuzione Dei Contratti. Milão: Giuffrè, 1950.

DE NOVA, G., Il Tipo Contrattuale, Cedam, Pádua, 1974, pp. 97 e ss.

DE NOVA, G., Nuovi Contratti. Il Diritto Attuale, no.10, 2a. ed. Turim: UTET, 1994.

DI MARZIO, F., (coord). Il Nuovo Diritto Dei Contratti-Problemi e Prospettive. Milão: Giuffrè, 2004.

DIB, A., Forms and agreements for Architects, Engineers and Contractors. V.1 Clark Boardman Company 1998.

DOCUMENT A201-1997 - General Conditions of the Contract for Construction, O modelo de Condições Gerais de Contrato de Construção do A.I.A (download on line)

DUDDECK, H. apud LESSAMAN H. E VIEDER, R., The Implications of Geotechnical Model Uncertainty for Construction Mangement, in Analyzing Uncertainty in Civil Engineering, Springer-Verlag,

EGGLESTON, K ; POSNER, E.; ZECKHAUSER, R., Simplicity and Complexity in Contracts, http://papers.ssrn.com/paper.taf?abstract_id=205391, p. 7. - consultado em 21.07.2006

ELIZABETH M. M. Q. F. et al., “Competitividade: Mercado, Estado e Organizações'. São Paulo: Editora Singular, 1997.

FARIA, J. E. E KUNTZ, R., Qual o Futuro dos Direitos?, Max Limonad, 2002, p. 100

FARIA, J. E., O Direito na Economia Globalizada, $1^{\text {a }}$ ed., São Paulo: Malheiros Editores, 2004. 
FÉDÉRATION INTERNATIONALE DES INGÉNIEURS-CONSEILS (FIDIC), Conditions of Contract for Construction; Conditions of Contract for EPC/Turnkey Project; , Short Form of Contract, Genebra, 1999.

FELDMAN, A., (verbete) Pareto Optimality, The New Palgrave Dictionary of Economics and the Law, Palgrave Macmillan, 2002, vol. 3, p. 6

FERRARESE, M. R, Diritto e Mercato - Il Caso degli Stati Uniti, Turim, G. Giappichelli Editore, 1992

FERRARESE, M. R., Le istituzioni della globalizzazione. Bolonha: Società Editrice Il Mulino, 2000.

FERRARESE, M., Mercati e globalizzazione. Gli incerti cammini del diritto in Le istituzioni della globalizzazione, Bologna, Mulino, 2000, p. 70:

FERRAZ JR., T. S., Introdução ao Estudo do Direito, São Paulo, Ed. Atlas, $4^{\mathrm{a}}$ ed., 2003, p. 87:

FIDIC , Fédération Internationale des Ingénieurs-Conseils, Turnekey Projects, Genebra, $1^{\mathrm{a}}$ ed. 1999 , p. 14

FISCHER-LESCANO, A., TEUBNER, G., "Regime-Collisions: The Vain Search for Legal unity in the Fragmentation of Global Law", vol. 25, Michigan Journal of International Law, 2004 999-1045.

FRIED, C., Contract as Promise - A Theory of Contractual Obligation, Cambridge, Harvard University Press, 1981

FRILET, M., capítulo sobre a França do livro FIDIC-An Analysis of International Construction Contracts, editor geral Knutson, R.; Kluwer Law International e International Bar Association, Haia, 2005, p. 87-126

GALGANO, F.; La globalizzazione nello specchio del diritto. Bolonha: Il Mulino, 2005.

GALLO, P., Sopravvenienza Contrattuale e Problemi di Gestione del Contratto, Milão: Giuffrè, 1992

GAMBINO, F., Problemi del Rinegoziare, Milão: Giuffrè, 2004

GHESTIN, J., BILLIAU, M., Le prix dans les contrats de longue durée. Paris: L.G.D.J., 1990.

GILMORE, G., The Death of Contract, 2a. ed. Columbus: Ohio State University Press, 1995. 
GOLBERG, V. P., (coord.) Readings in the economics of contract law. Cambridge: Cambridge University Press, 1993.

GONZÁLES, M.; ARRUÑADA, B.; FERNÁNDEZ, A., Causes of Subcontracting Evidence from Panel Data on Construction Firms, University Pompeu Fabra Economics and Business Working Paper No. 428. disponível em SSRN:

http://ssrn.com/abstract $=224551$

GORDLEY, J., Mistake in Contract Formation, American Journal of Comparative Law, vol. 52, 2004 pp. 433-468.

GORDLEY, J., The Philosophical Origins of Modern Contract Doctrine. Oxford: Clarendon Press, 1992.

GRAU, E.; FORGIONI, P., O Estado, A Empresa e o Contrato, São Paulo, Malheiros, 2005

GRAU, E.; O Direito Posto e o Direito Pressuposto, $6^{a}$ ed. São Paulo, Malheiros, 2005

GRYNBAUM, L. , Le Contrat Contingent - L'Adaptation du Contrat par le Juge Sur Habilitation du Législateur, Paris, L.G.D.J., 2004

GUESTIN, J. ; JAMIN, C. ; BILliAU, M., Traité de Droit Civil - Les Effets du Contrat, $2^{a}$ ed., Paris: L.G.D.J., 1994.

HARTMAN, F; SNELGROVE, P, Risk Allocation in Lump-Sum Contracts - Concept of a Latent Dispute, Journal of Construction, Engineering and Management, September 1996, p. 291

HERMALIN, B. et al., "The Handbook of Law and Economics", a ser editado, disponível em SSRN: http://ssrn.com/abstract=907678, visto em 15.09.2006, p. 65

HETLAND, P. W., Uncertainty Management, in Appraisal, Risk and Uncertainty, Smith, N. editor; Thomas Telford Publishing, Londres, 2003, p. 72

HSIUNG, B., The Commonality between Economics and Law, vol. 18, European Journal of Law and Economics, 2004.

HUET, J., Les principaux contrats spéciaux, Traité de Droit Civil, dir. Jacques Guestin, Paris, L.G.D.J., $2^{\mathrm{a}}$ ed., 2001.

JACKSON, H. E. et al., Analytical Methods for Lawyers. Nova York: Foundation Press, 2003.

KLEIN, B., (verbete) Hold-up Problem, The New Palgrave Dictionary of Economics and the Law, editado por Newman, P., Palgrave Macmillan, 2002, vol. 2, p. 243 
KNIGHT, F H., Risk, Uncertainty and Profit, 1921, Cosimo, Nova York

KOTOWITZ, Y., (verbete) Moral Hazard, The New Palgrave: A Dictionary of

Economics, The Macmillan Press Ltd., 1991 (reimpressão de 1996), vol. 3, p. 549

KRONMAN, A. T.; POSNER, R., The Economics of Contract Law, Boston, Little, Brown and Company, 1979

LAPERTOSA, F., L'Engineering, Milão: Giuffrè, 1993.

LARENZ, K., Derecho Civil - Parte General (tradução de Allgemeiner Teil des deutschen Bürgerlichen Rechts), Madrid: Editorial Revista de Derecho Privado Editoriales de Derecho Reunidas, 1978.

LARENZ, K., Metodologia da Ciência do Direito. 2ª ed., Lisboa: Fundação Calouste Gulbenkian, 1983.

LARENZ, K., Base del Negocio Jurídico y Cumplimiento de los Contratos, trad. Carlos Fernandez Rodriguez, Granada, Editorial Comares, 2002.

LAW, J. E MOL, A., Complexities; An Introduction, in Complexities: Social Studies of Knowledge Practices, 2006 (segunda impressão) Duke University Press, Durham e Londres, , p. 3.

LESSARD, D.; MILLER, R., Mapping and Facing the Landscape of Risks", in The Strategic Mangement of Large Engineering Projects - Shaping Institutions, Risks and Governance, editors Miller, R e Lessard, D., The MIT Press, Cambridge, 2000, p. 81

LEÃES, L, A Onerosidade Excessiva no Código Civil, Revista de Direito Bancário e do Mercado de Capitais, vol. 31, ano 9, jan-mar de 2006, pp. 19-20

LEVITT, R.; ASHLEY, D. LOGCHER, R, Allocating Risk and Incentive in Construction; Journal of the Construction Division (ASCE), vol. 106, $\mathrm{n}^{\mathrm{o}} 3$, setembro 1980, p. 299.

LOPES, T. A., Comentários ao Código Civil-Parte Especial-Das Várias Espécies de Contratos; vol. 7; São Paulo, Editora Saraiva, 2003, p. 299

LIPSHAW, J. M., Contingency and Contracts: A Philosophy of Complex Business Transactions, Depaul Law Review, vol. 54., pp. 1073-1142.

LUHMANN, N., Law as a Social System, Oxford: Oxford University Press, 2004.

LUHMAN, N.; Risk - A Sociological Theory, New Brunswick (USA), Aldine Transaction Publishers, 2005, p. 16: 
MCCANN, JR., C. R., Conceptions of Probability, in The Elgar Companion to Economics and Philosophy, ed. By Davis, J. B., Marciano, A e Runde, J.- Edward Elgar, Cheltenham, 2004, p. 459

MACNEIL, I.R., Whither Contracts?, Journal of Legal Education, vol. 21, pp. 403-418. 1969

MCCANN, JR., C. R., Conceptions of Probability, in The Elgar Companion to Economics and Philosophy, ed. By Davis, J. B., Marciano, A e Runde, J.- Edward Elgar, Cheltenham, 2004, p. 459

MACNEIL, I. E., The Many Futures of Contracts, Southern California Law Review, (1974), vol. 47, p. 755

MACNEIL, I. R.; GUDEL, P. J., Contracts - Exchange Transactions and Relations Cases and Materials. 3a. ed., Nova York: Foudation Press, 2001.

MACNEIL, I.; CAMPBELL, D., The Relational Theory of Contract: selected works of Ian Macneil. Londres: Sweet \& Maxwell, 2001.

MAINE, H.S., Ancient Law - Its Connection with th Early History of Society and its Relation to Modern Ideas, Dorset Press, 1986, p. 267

MARINELLI, F., Engineering; in I Nuovi Contratti Nella Prassi Civile e Commerciale, vol XIII - Strutture industriale e tecnologiche; Turim, UTET, 2004, p.p. 28-29

MARQUES, C. L., Comentários ao Código de Defesa do Consumidor, $2^{\mathrm{a}}$ Ed., São Paulo, RT, 2006, p. 694

MARTINS-COSTA, J., Comentários ao Código Civil, vol. V, Tomo I. Rio de Janeiro, Forense, 2003, p. 257

MARTINS-COSTA, J., A Revisão dos Contratos no Código Civil Brasileiro: trabalho apresentado nas XIX Jornadas Nacionales de Derecho Civil, Rosario, Argentina, 25 a 27 de setembro de 2003, disponível em http://200.61.186.245/civil/MartinsCosta\%20(Com.3).pdf:

MARTINO V,. La risoluzione per eccessiva onerosità: in I Contratti in Generale, coleção Il Diritto Privato Nella Giurisprudenza - a cura de Cendon, P. - vol. XIII, Turim, UTET, 2000, pp. 521-580.

MASCARELLO, C., Il Contratto di Appalto, Milão: Giuffrè, 2002.

MASTEN, S. E. (Editor), Case Studies in Contracting and Organization, Nova York, Oxford University Press, 1996. 
MEDEIROS DA FONSECA, A., Caso Fortuito e Theoria da Imprevisão, Rio de Janeiro, Forense, $3^{\mathrm{a}}$ ed., 1958.

MERCURO, M.; MEDEMA, S., Economics and the Law - From Posner to PostModernism, Princeton, Princeton University Press, 1997.

MOTA PINTO, C.A., Teoria Geral do Direito CiviI, Coimbra, Coimbra Editora, $3^{\text {a }}$ ed., 1990, p. 343

MUSY, A. M., La Comparazione Giuridica Nell'Età Della Globalizzazione. Milão: Giuffré, 2004.

NERY JR., N.; ANDRADE NERY, R. M., Código Civil Comentado e Legislação Extravagante, São Paulo, RT, 4ª ed., 2006.

NETTO, A. et al., The Contra Preferentem Rule and Standard Forms of Construction Contracts, International Construction Law Review, vol. 19, part 3, julho 2002, p. 387

NORTH, D. C., Institutions, Transaction Costs and the Rise of Merchant Empires, in The Political Economy of Merchant Empires, James D. Tracy, editor, Cambridge: Cambridge University Press, 1997.

OSTI, G., La cosi detta clausola 'rebus sic stantibus' nel suo sviluppo storico, Rivista de Diritto Civile, p.1-58, Anno IV, 1912.

OSTI, G., Appunti per una teoria della 'sopravvenienza, Rivista di Diritto Civile, Anno V,pp. 471-498, 1913

PACHECO, P. M., El Análisis Económico del Derecho - Una Reconstrucción Teórica, Madrid, Centro de Estudios Constitucionales, 1994.

PARISI, F., Positive, normative and functional schools in law and economics, in The Elgar Companion to Law and Economics, Ed. Jürgen G. Backhaus, 2a ed. 2005, Edward Elgar, Cheltenham, Grã Bretanha, 2005, pp. 58-73.

PARKER; ADAMS, The A.I.A. Standard Contract Forms and the Law (1954), apud, Bruner, P e O’Connor, Jr,, op. cit., §5:1, p. 12.

PERFETTI, U., L'Ingiustizia Del Contratto. Milão: Giuffré, 2005.

PERILLO, J., Misreading Oliver Wendell Holmes on Efficient Breach and Tortious Interference, Fordham Law Review, Vol. 68, 2000, http://ssrn.com/abstract=241263

PETROSKI, H., To Engineer is Human: The Role of Failure in Successful Design, New york, Vintage Books, 1992, p. 43 
POLINSKY, A. M., An Introduction to Law and Economics, $3^{\mathrm{a}}$ ed., Nova York: Aspen Publishers, 2003.

PONTES de MIRANDA, Tratado de Direito Privado, Tomo XLIV, Revista dos Tribunais, São Paulo, 1984, $3^{\mathrm{a}}$ ed., $2^{\mathrm{a}}$ reimp., pp. 375-376.

POSNER, R., The Problematics of Moral and Legal Theory, The Belknap Press of Harvard University Press, Cambridege, 1999.

POSNER, R., Economic Analysis of Law, Aspen Publishers, New York, $6^{\mathrm{a}}$ ed., 2003, pp. 105 e ss

RONDINONE, N., Storia Inédita della Codificazione Civile, Milão: Giuffrè, 2003.

ROPPO, V., Il Contratto, Milão: Giuffré, 2001.

ROPPO, V., Il Contratto del Duemila, Turim: G. Giappichelli Editore, 2002.

ROSENER, W.; DORNER, G., capítulo sobre a Alemanha do livro FIDIC-An Analysis of International Construction Contracts, editor geral Knutson, R.; Kluwer Law International e International Bar Association, Haia, 2005, p. 79-86.

SANTOS, B. S., Os Processos da Globalização, in "Globalização - Fatalidade ou Utopia?”, Boaventura de Sousa Santos [org.], 2ª ed. Portugal: Edições Afrontamento, 2002.

SICCHIERO, G., L'Engineering, La Joint Venture, I Contratti di Informática, I Contratti Atipici di Garanzia, Turim, UTET, 1991, p. 37

SCHWAB, D., Einführung in das Zivilrecht, Heidelberg, 16. Auflage, 2005, C.F. Müller.

SCHWARTZ, A., (verbete) Incomplete Contracts, The New Palgrave Dictionary of Economics and the Law, Palgrave Macmillan, 2002, vol. 2, p. 277

SCHWARTZ, A.; SCOTT, R. E., Contract Theory and the Limits of Contract Law, vol. 113, Yale Law Journal, 2003.

SENECA, L. A,“'De Beneficiis”, Tradução de Aubrey Stewart, 1887, disponível em: http://www.gutenberg.org/dirs/etext03/bnfts10.txt

SHAVELL, S., Foundations of Economic Analysis of Law. Cambridge: The Belknap Press of Harvard University Press, 2004.

SHAVELL, S., Contracts, Holdup and Legal Intervention, Harvard John M. Olin Discussion Paper Series, discussion paper $n^{0} 508$ (03/2005), disponível em http://www.law.harvard.edu/programs/olin_center/ 
SHAVELL, S. et al.; Analytical Methods for Lawyers, Foundation Press, 2003, seção sobre "production contracts", pp. 74 a 88.

SHAVELL, S., Is Breach of Contract Immoral? Harvard John M. Olin Discussion Paper Series, discussion paper $\mathrm{n}^{\mathrm{o}} 531$ (11/2005), disponível em http://www.law.harvard.edu/programs/olin_center/.

SICCHIERO, G., L'Engineering, La Joint Venture, I Contratti di Informática, I Contratti Atipici di Garanzia, Turim: UTET, 1991.

SWEET, J., SCHNEIER, M. M., Legal Aspects of Architecture, Engineering and the Construction Process, Toronto, Thomson Canada, $7^{\text {a }}$ ed. 2004

SWEET, J., Confessions of a Law Teacher, International Construction Law Review, vol. 18,2001, p. 541

STIT, W. B, Corporate Practice of Engineering, The Business Lawyer, vol. 14, julho/1959, pp. 969-988.

SZTAJN, R., Contrato de Sociedade e Formas Societárias, São Paulo, Saraiva,1989, p. 14.

SZTAJN, R., Externalidades e Custos de Transação: A Redistribuição de Direitos no Novo Código Civil, Revista de Direito Mercantil, Industrial, Econômico e Financeiro, vol. 133, São Paulo: Malheiros, jan-mar. 2004.

WILliAMSON, O. E., (verbete); Opportunistic Behavior in Contracts, The New Palgrave Dictionary of Economics and the Law, Palgrave Macmillan, 2002, vol. 2, p. 704

TELlES JUNIOR, G., Tratado da Conseqüência - Curso de Lógica Formal, São Paulo, Ed. Juarez de Oliveira, $6^{\text {a }}$ ed. 2003, p. 297.

TRABUCCHI, A.; TABUCCHI G., (coord.); Istituzioni di Diritto Civile. 41a. ed., Pádua: CEDAN, 2004.

TREBILCOK, M. J., The Limits of Freedom of Contract, Cambridge, Harvard University Press, 1993.

TRIANTIS, G., in Encyclopedia of Law and Economics - Volume III - the Regulation of Contracts, Bouckaert, B e De Geest, G, ed.; Edward Elgar Pub. Ltd, Cheltenham, 2001 (reimpressão).pp. 100-116

TUlliO, A., La Finanza di Progetto: Profili Civilistici, Milão: Giuffrè, 2003

UNCITRAL - Legal Guide on Drawing up International Contracts for the Construction of Industrial Works, Nações Unidas, New York, 1988 - também disponível em: 
http://www.uncitral.org/uncitral/en/uncitral texts/procurement infrastructure/1988Guide .html (consultado em 30.11.2006).

WALLACE, D. G., Hudson's Building and Engineering Contracts. 11a. ed., vol. 1, Londres: Sweet \& Maxwell, 1995.

WANG, J. X.; ROUSH, M., Risk Engineering - Dealing with System Complexity and Engineering Dynamics, in What Every Engineer Should Know about Risk Engineering and Management, Nova York, Marcel Dekker, 2000

WEBER, M., Economía y Sociedad, México: Fondo de Cultura Económica, 1987.

WILLIAMSON, O., E. The Economic Institutions of Capitalism - Firms, Markets, Relational Contracting. Nova York: The Free Press, 1987.

WILLIAMSON, O.; WINTER, S. G., The Nature of the Firm-Origins, Evolution and Development, New York, Oxford University Press, 1991.

WILlIAMSON, O. E.; MASTEN, S. E., The Economics of Transaction Costs. Cheltenham: Edward Elgar, 1999.

YAU, M., CHAN, E, Attitudes of Contractors and Employers Towards Transfer of a Time-Related Risk in Construction Contracts, [American Society of Civil Engineers ASCE - Construction Research Congress, 2005, Broadening Perspectives, Proceedings of the Construction Research Congress 2005 held in San Diego, California, April 5-7, 2005 - doi: 10.1061/40754(183)68

http://ascelibrary.aip.org/dbt/dbt.jsp?KEY=ASCECP\&Volume=183\&Issue=40754\&bpro $\mathrm{c}=$ year $\&$ scode $=2005 \&$ conf Title $=$ Construction + Research + Congress $+2005-$ consultado em 23.10.2006].

ZYLBERSZTAJN, D.; SZTAJN, R., Direito \& Economia - Análise Econômica do Direito e das Organizações, Rio de Janeiro: Editora Campus-Elsevier, 2005. 